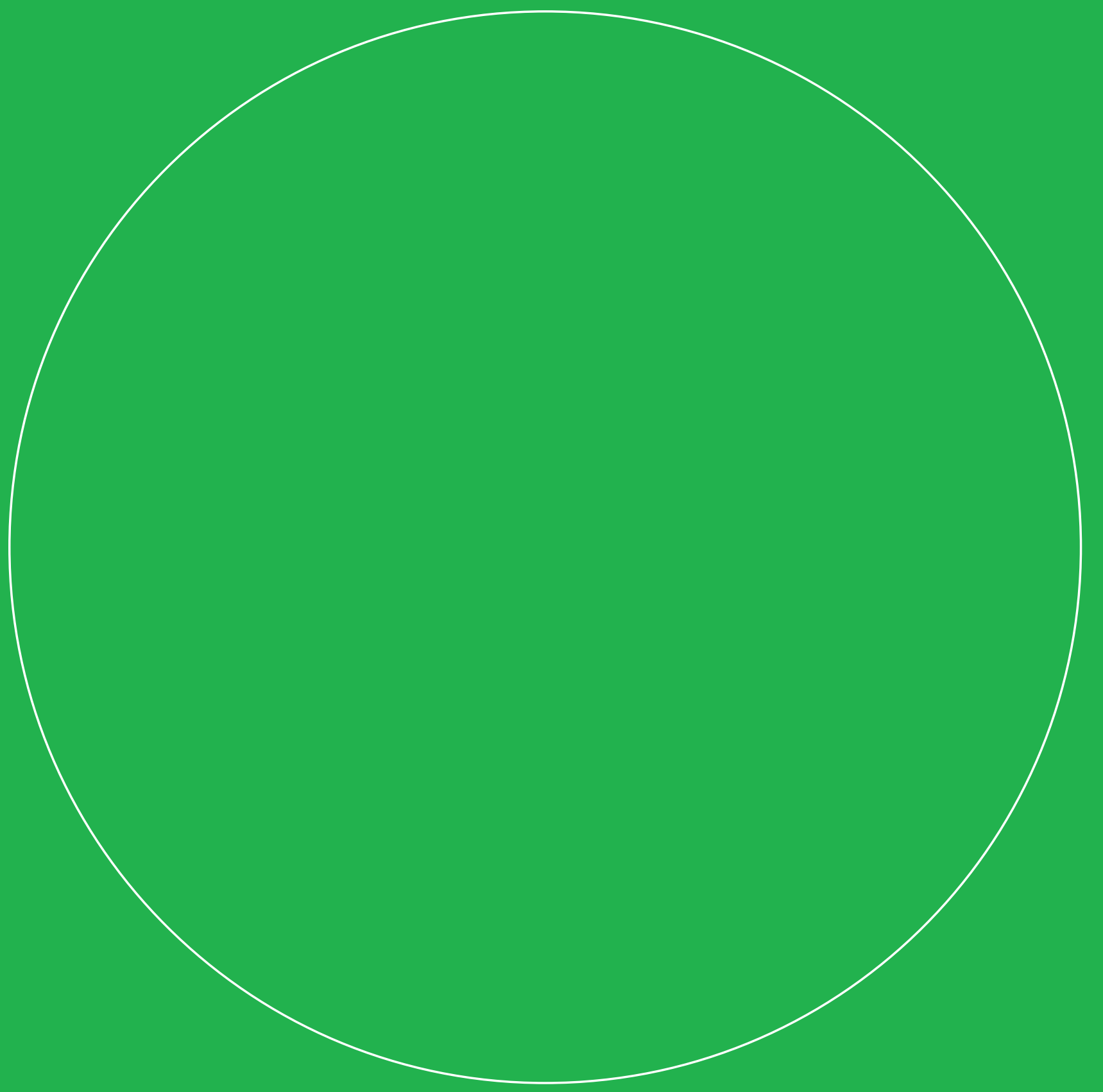

\title{
Inventory report: Dutch Smart Chains for transport of perishable products
}





\section{Inventory report: Dutch Smart Chains for transport of perishable products}

Author: Xuezhen Guo

Institute: Wageningen Food \& Biobased Research

This research project has been carried out by Wageningen Food \& Biobased Research commissioned by the Dutch Ministry of Economic Affairs and funded by RDA, South Korea, in the context of Smart Chain (project number 62391579-00).

Wageningen Food \& Biobased Research

Wageningen, September 2018

Report 1862

ISBN 978-94-6343-362-4 
Version: final

Reviewer: Han Soethoudt

Approved by: Nicole Koenderink

Client: the Dutch Ministry of Economic Affairs

Sponsor: RDA, South Korea (WUR-RDA project coordinator, Suntay Choi)

This report can be downloaded for free at https://doi.org/10.18174/460856 or at www.wur.eu/wfbr (under publications).

(C) 2018 Wageningen Food \& Biobased Research, institute within the legal entity Stichting Wageningen Research.

The client is entitled to disclose this report in full and make it available to third parties for review. Without prior written consent from Wageningen Food \& Biobased Research, it is not permitted to:

a. partially publish this report created by Wageningen Food \& Biobased Research or partially disclose it in any other way;

b. (let a third party) use this report created by Wageningen Food \& Biobased Research or the name of the report or Wageningen Food \& Biobased Research in whole or in part for the purposes of making claims, conducting legal procedures, for (negative) publicity, and for recruitment in a more general sense;

c. use the name of Wageningen Food \& Biobased Research in a different sense than as the author of this report.

PO box 17, 6700 AA Wageningen, The Netherlands, T + 31 (0)317 4800 84, E info.wfbr@wur.nl, www.wur.eu/wfbr. Wageningen Food \& Biobased Research is part of Wageningen University \& Research.

All rights reserved. No part of this publication may be reproduced, stored in a retrieval system of any nature, or transmitted, in any form or by any means, electronic, mechanical, photocopying, recording or otherwise, without the prior permission of the publisher. The publisher does not accept any liability for inaccuracies in this report. 


\section{Contents}

$\begin{array}{lr}\text { Summary } & 4\end{array}$

$\begin{array}{lr}\text { 1. Introduction } & 5\end{array}$

$\begin{array}{lll}\text { 2. Introduction of Dutch Agri-product Export Status } & 7\end{array}$

3. Recent issues related to postharvest technology development in EU and the $\begin{array}{ll}\text { Netherlands } & 10\end{array}$

3.1 The new trends in the postharvest fresh produce chains $\quad 10$

3.2 Postharvest technologies and management to prevent food losses 10

3.3 A list of postharvest technology R\&D projects carried out by WUR 13

3.3.1 Controlled Atmosphere $\quad 13$

$\begin{array}{ll}3.3 .2 \text { Infrastructure related } & 16\end{array}$

$\begin{array}{lr}3.3 .3 \text { Packaging } & 19\end{array}$

4. Smart chain $r 22$

$\begin{array}{lll}4.1 & \text { Basic concept } & 22\end{array}$

4.2 Smart Decision Support $\quad 23$

4.2.1 Simulation technology 23

$\begin{array}{ll}\text { 4.2.2 Quality change prediction model } & 24\end{array}$

$\begin{array}{ll}\text { 4.2.3 Smart Fresh logistics } & 27\end{array}$

$\begin{array}{ll}\text { 4.2.4 Big data and postharvest technologies } & 28\end{array}$

$\begin{array}{lll}4.3 & \text { Smart chain application in real cases } & 30\end{array}$

4.3.1 Pineapple Case $\quad 30$

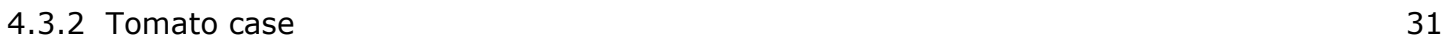

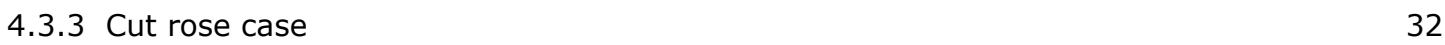

$\begin{array}{lll}4.4 & \text { Potential smart chain applications in South Korea } & 34\end{array}$

$\begin{array}{ll}\text { 5. Future challenges } & 37\end{array}$

$\begin{array}{lll}\text { 6. Discussion and conclusion } & 38\end{array}$

$\begin{array}{lr}\text { Reference } & 39\end{array}$

$\begin{array}{lr}\text { Appendix } & 41\end{array}$ 


\section{Summary}

There is a strategic collaboration between Rural Development Administration(RDA) from South Korea and Wageningen University \& Research (WUR) from the Netherlands. RDA is a similar organisation to Stichting Wageningen. RDA has a Liaison in WUR, who is Dr. Suntay Choi. He is responsible for the bilateral collaboration between RDA and Wageningen. At present 12 RDA-WUR projects are being implemented, all financed by RDA. Dr. Choi would like to set up a small project on "smart chains" applications in Dutch postharvest fresh produce chains. Together with a delegation from the RDA Export supporting centre, he visited Wageningen Food \& Biobased Research (FBR) on 14 May 2018. In that visit he has asked for an inventory (desk study) of available postharvest technologies and management experience in this field in the Netherlands, and possible applications in South-Korea. A similar study has been done for smart farming in pig production and greenhouse horticulture by Wageningen Economic Research (WEcR).

The Netherlands as the fresh/logistic hub in Western Europe is the leading player in the global agroproduct market. The Netherlands have developed advanced postharvest technologies to reduce postharvest losses by improving the storage and transport conditions of fresh products in the fresh produce chains. They are also engaged in establishing the so called "smart chain" to achieve better chain efficiency and coordination. Such experience has placed the Netherlands as worldwide leading in fresh produce supply chain solutions. Part of this experience can be learned by South Korea.

This project elaborates the recent developments of postharvest technologies and management in Europe, especially in the Netherlands. The main message this report wants to convey to the readers is that smart/advanced technologies do not work by themselves; they need other factors specific to certain conditions to result in significant improvements. Therefore, the essence of "smart chain" is in fact optimally using the technologies and resources at hand to deliver products that satisfy the market demands and create the largest chain values. 


\section{Introduction}

South Korea is famous for its high-tech industry. However, it is also known for the greenhouse production of vegetables (tomato, pepper, cucumber, eggplant) and export of sweet pepper to Japan. The Korean government wants to increase the export of fresh vegetables (peppers) and fruits (strawberries) to Asian countries, especially to China, Japan, Singapore. In other words, South Korea aims to be the fresh hub for Asia. The Korean RDA wants to learn about the application of smart chains for transport of perishable/(horticultural) products (fruits, vegetables and flowers) in the Netherlands.

The Netherlands is the world's second largest exporter of agricultural products, the world's top exporter of potatoes and onions and the second largest exporter of vegetables overall in terms of value $^{1}$. In addition, the Netherlands is the primary source of propagation material and technological developments or the global horticultural industry. The Netherlands is well positioned to contribute to the global pursuit of greater well-being and prosperity, as well as a sustainable world.

The research question posed by the client is why the Netherlands perform so superior in its fresh produce supply chains.

Since Wageningen UR is the major Dutch "idea bank" for agriculture-related topics, WFBR as part of Wageningen UR which has world-wide reputation in postharvest smart chain studies is thereby the most appropriate institute to deliver this report. This report is not only for the internal use by RDA. The client also gives the permission for the public accesses to contribute the knowledge to the broader audiences.

The chosen approach to answer the research question, is not to simply list the postharvest technologies and managerial methods to the end users, but also to provide a framework to describe the "postharvest smart chain" in a structural way.

The remaining paper is structured in the following way (see the schematic overview in Figure 1 ). In chapter 2, statistics of the Dutch agro exports are provided to demonstrate the strong position of the Netherlands in the global fresh produce market. Chapter 3 addresses the technological aspects of the smart chain: the postharvest technologies. We refer those technologies as "hardware" compared to the "software" addressed in chapter 4 which concerns how to effectively organize the hardware and use it in a smart way. The software reflects the smart part of the fresh produce supply chain and is further distinguished into four approaches to support smart decision making (i.e., the simulation technique, quality change predication model, fresh logistics management, big data and postharvest technology). The last part of chapter 4 discusses the potential application of the "smart chain" techniques in South Korea fresh produce chain. Chapter 5 focuses on the elaboration on the future challenges faced by the fresh produce chain to apply the smart chain approach. In chapter 6 , the previous is discussed and conclusions are drawn.

As presented in Figure 1 the concept of hardware and software developed by WFBR are used to differentiate the different aspects in the fresh produce chains. According to WFBR's definition, hardware covers the physical and technical aspects of a supply chain. Therefore, the postharvest technologies introduced in chapter 3 belong to this category. The software concerns the ability of improving the skills of the stakeholders in the chain. The smart decision support approaches described in chapter 4 therefore falls into this category. In the WFBR's definition, there is also a term called "orgware" concerning the structure and organization of the stakeholders in the supply chain which are out of the scope of this study.

\footnotetext{
1 https://www.nationalgeographic.com/magazine/2017/09/holland-agriculture-sustainable-farming/ ,viewed 28-9-2018
} 
Due to the purpose of this inventory study (to provide the overview of the postharvest and smart chain technologies) and also because of the time and budget limitation, in this report it is not possible to conduct in-depth analysis of each touched point. We have to somehow scarify the details to ensure a broader coverage of the topics, which also leaves room for conducting future projects.

Last but not least, although the main focus of the report is on long-distance transportation of the fresh products, we also touched the points of short-distance transportation organization (e.g. last-mile delivery). This is because to optimize the whole chain from a logistics point of view, we cannot separate the long-distance and short-distance transport networks.
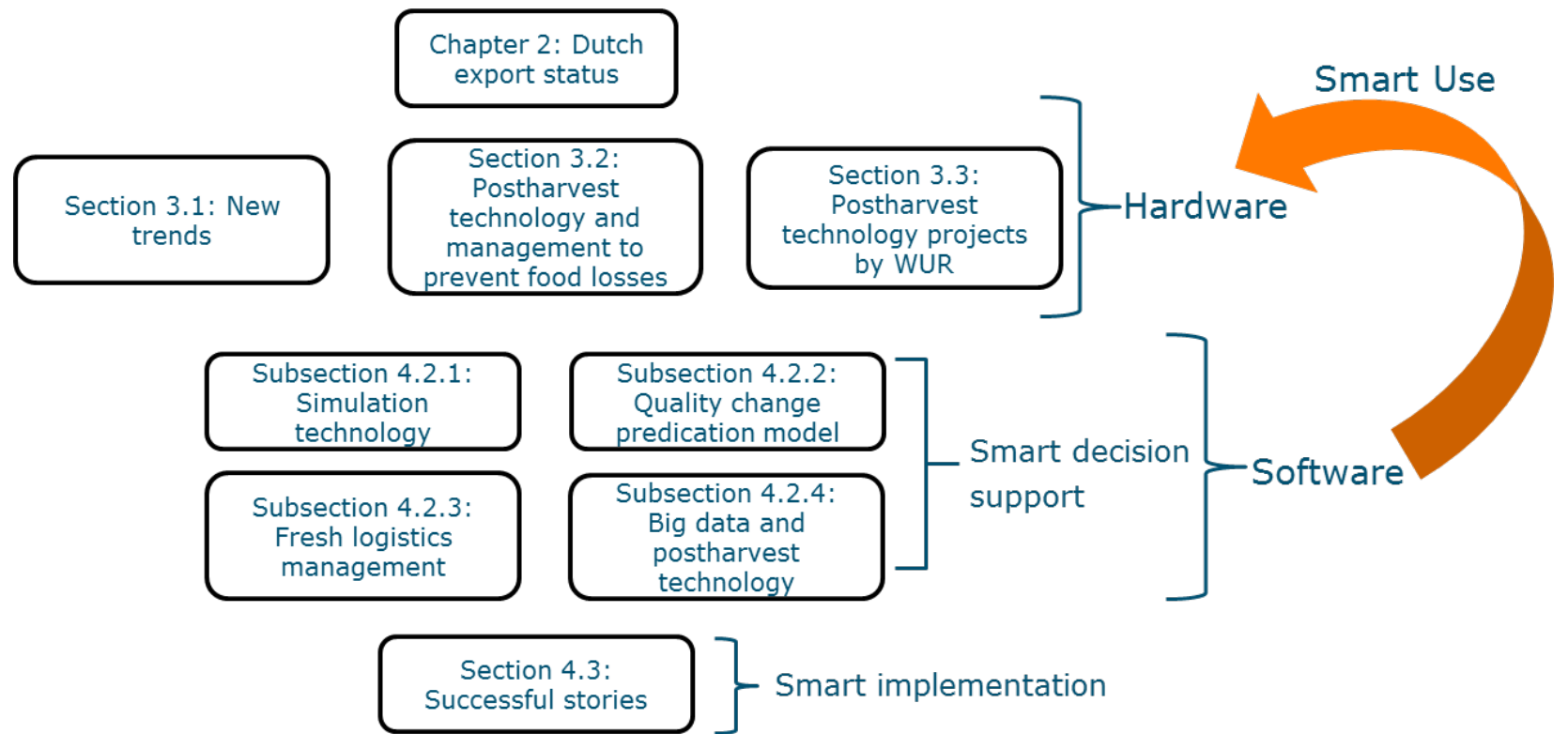

Section 4.4

Potential applications

in South Korea

Chapter 5: Future

Challenges

Chapter 6:

Discussion and

conclusion

Figure 1. Schematic overview of the remaining part of the report

All in all, the major conclusion of this report is that smart chain does not mean the advanced postharvest technologies themselves but the skills/capabilities to apply those technologies in the smart way. 


\section{Introduction of Dutch Agri-product Export Status}

The Netherlands is famous for its prosperous agro-food sector characterized by its high productivity and leading export position in the global market. Last September, the National Geographic magazine made an in-depth reporting with the tile "This tiny country feeds the world" to introduce the successful Dutch story, which has made a far-reach influence. It considers the Netherlands as an agricultural giant by presenting a typical model of the future agriculture (Viviano, 2017).

The area of the Netherlands is $41,543 \mathrm{~km}^{2}$, which only ranks the $131^{\text {st }}$ globally. With such a tiny land, the Netherlands manages to become the second largest agricultural product exporter in 2017 just next to the united states (DutchNews. $\mathrm{nl}, 2018$ ). This is not an accidental one-off event. Dutch agricultural sector has a long history of its leading export position in the global market. Figure 2 presents the trend of agro-product exports for the Netherlands during the period 1996-2016 compared to other large economies. During the last two decades, Netherlands exports more agricultural products than most other countries do and it constantly ranks the second or third on the list of the global agro-product exporters.

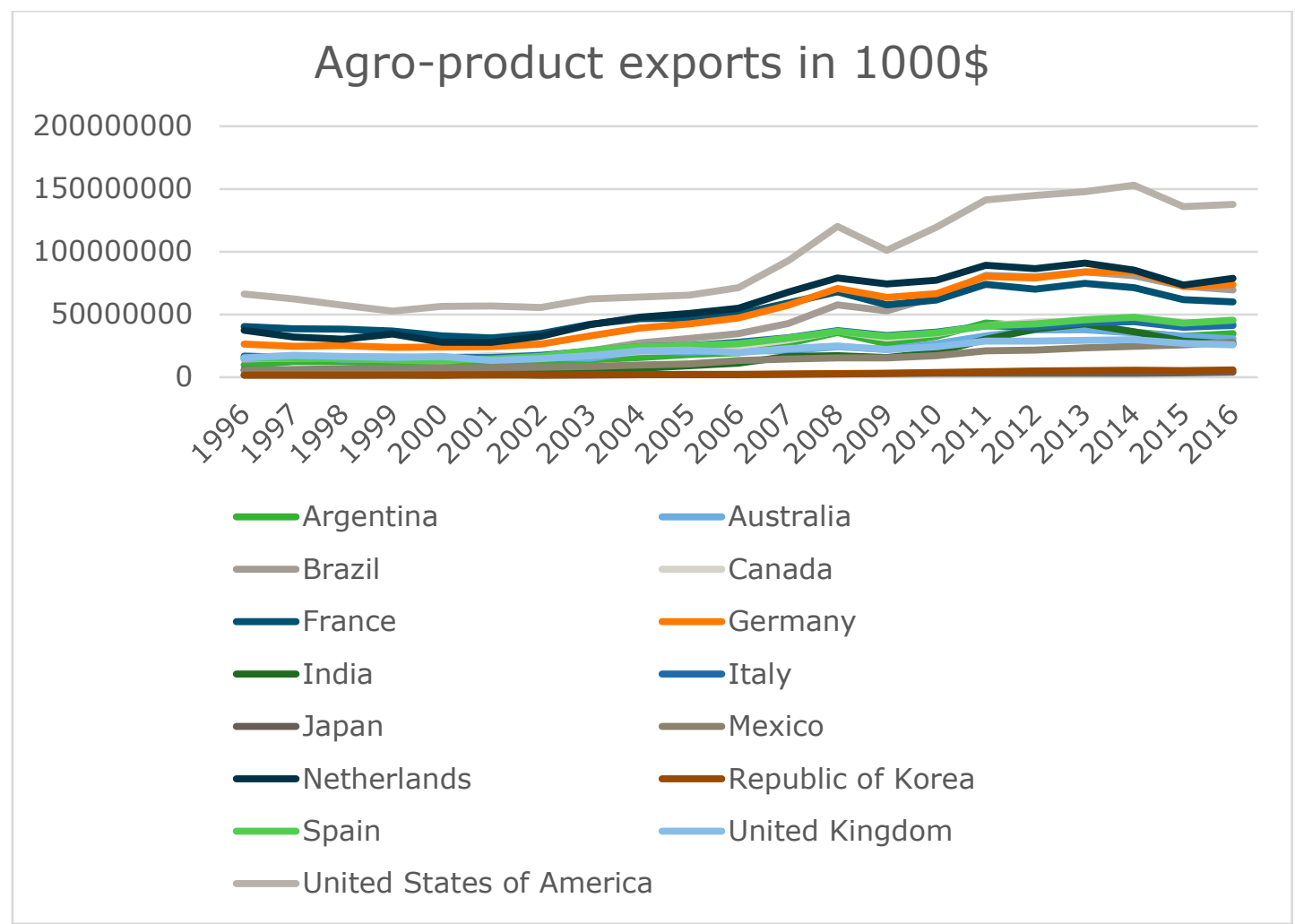

Figure 2. The annual agro-product exports (excluding cut flowers, bulbs, plants and nursery products) for some world major economies from 1996 to 2016 (Source: FAO)

European countries are the major exporting destinations for Dutch agricultural products (Figure 3). Among the top 10 export destinations, 8 are the European Union member countries, revealing the heavy dependency of Dutch agricultural sector on the EU market. Germany is the biggest importer of Dutch agro products, which imports more than a quarter of total Dutch exports. It is followed by Belgium, UK, France, Italy and Spain which jointly account for another one third of the total exports. The united states and China are the only two non-EU countries among the top 10 export destinations but they in combination only import 5\% of total Dutch agricultural exports. All the top ten markets have observed an increase of buying from 2016 to 2017. However, the increase rate for UK from 2016 
to 2017 are relatively low which is possibly related to adverse exchange rate developments due to the upcoming Brexit (CBS, 2018).

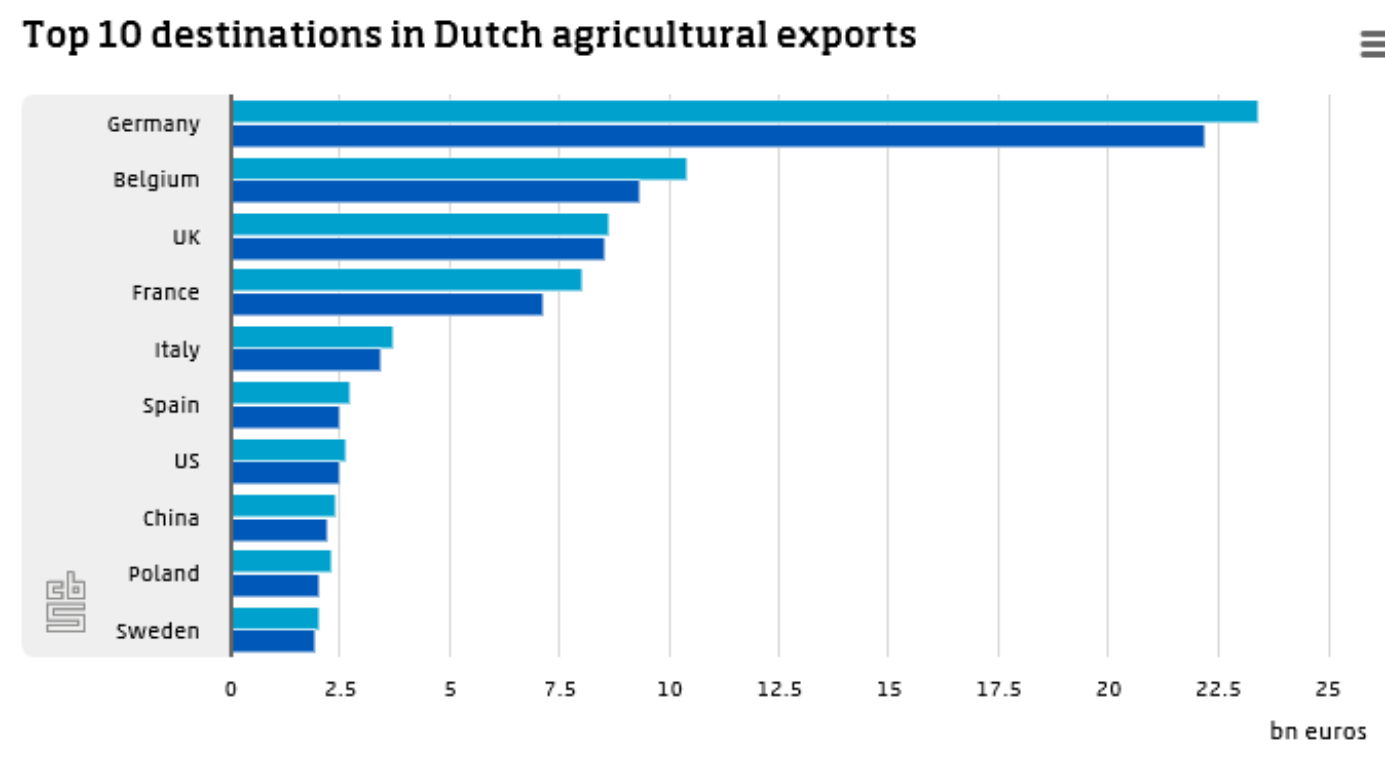

Source: CBS until Nov. 2017, estimates Nov. and Dec. 2017 by Wageningen Economic Research and CBS

\section{Figure 3. Major Dutch agro-product export markets}

Among the total agricultural exports, horticulture is the largest product category followed by dairy, meat, vegetables and fruits (Figure 4).

\section{Top 10 Dutch agricultural exports}

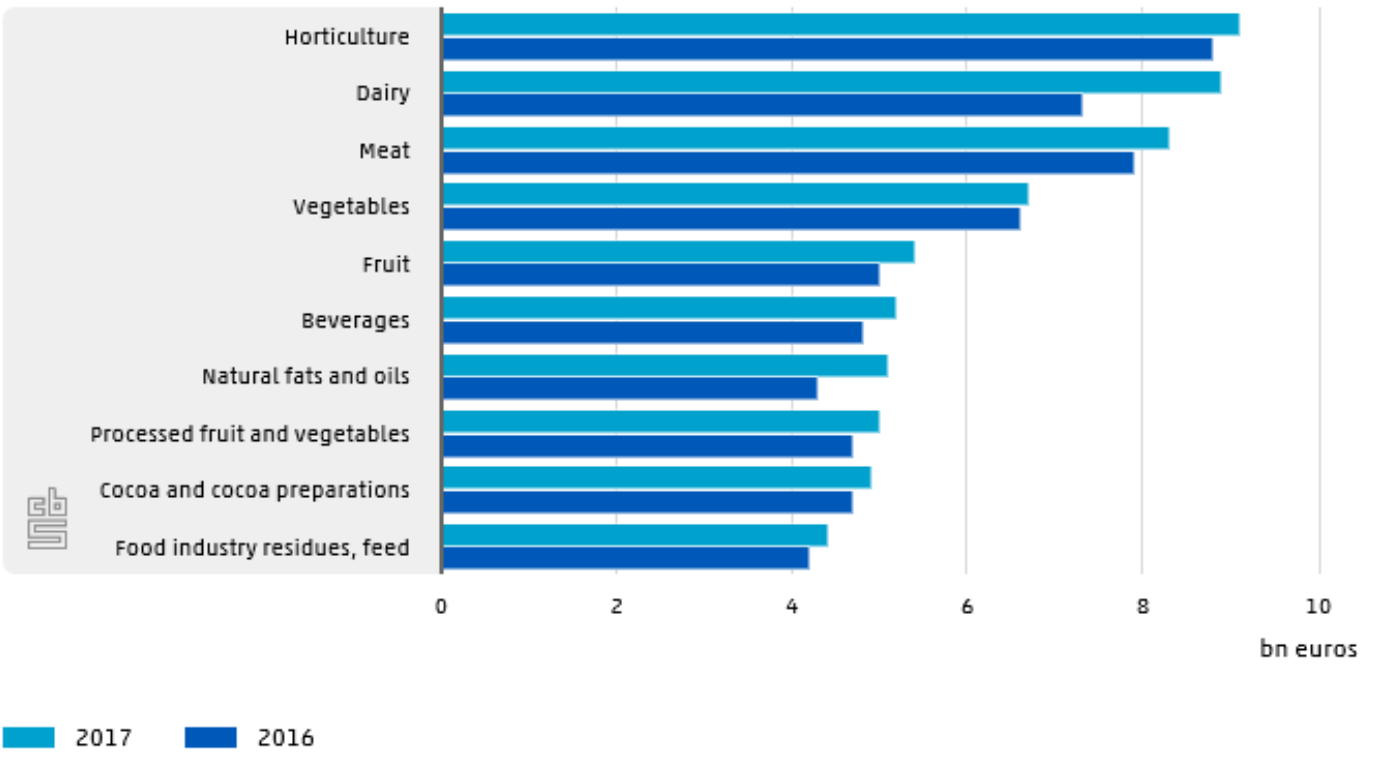

Source: CBS until Nov. 2017, estimates for Nov. and Dec. 2017 by Wageningen Economic Research and CBS

\section{Figure 4. Major Dutch agricultural products for exports}

The most vulnerable fresh product categories, horticulture ${ }^{2}$, vegetables and fruit (i.e. the fresh plant products) make up almost a quarter of the total agricultural exports. It on the one hand reveals the important positions of those products in the Dutch agriculture sector and on the other hand

2 The horticulture category includes cut flowers, bulbs, plants and nursery products (CBS). 
demonstrates the advancement of Dutch post-harvest technologies and the associated smart chain applications that deliver the excellent results in freshness maintenance.

\section{Major fruits and vegetables exports in $1000 \$$}

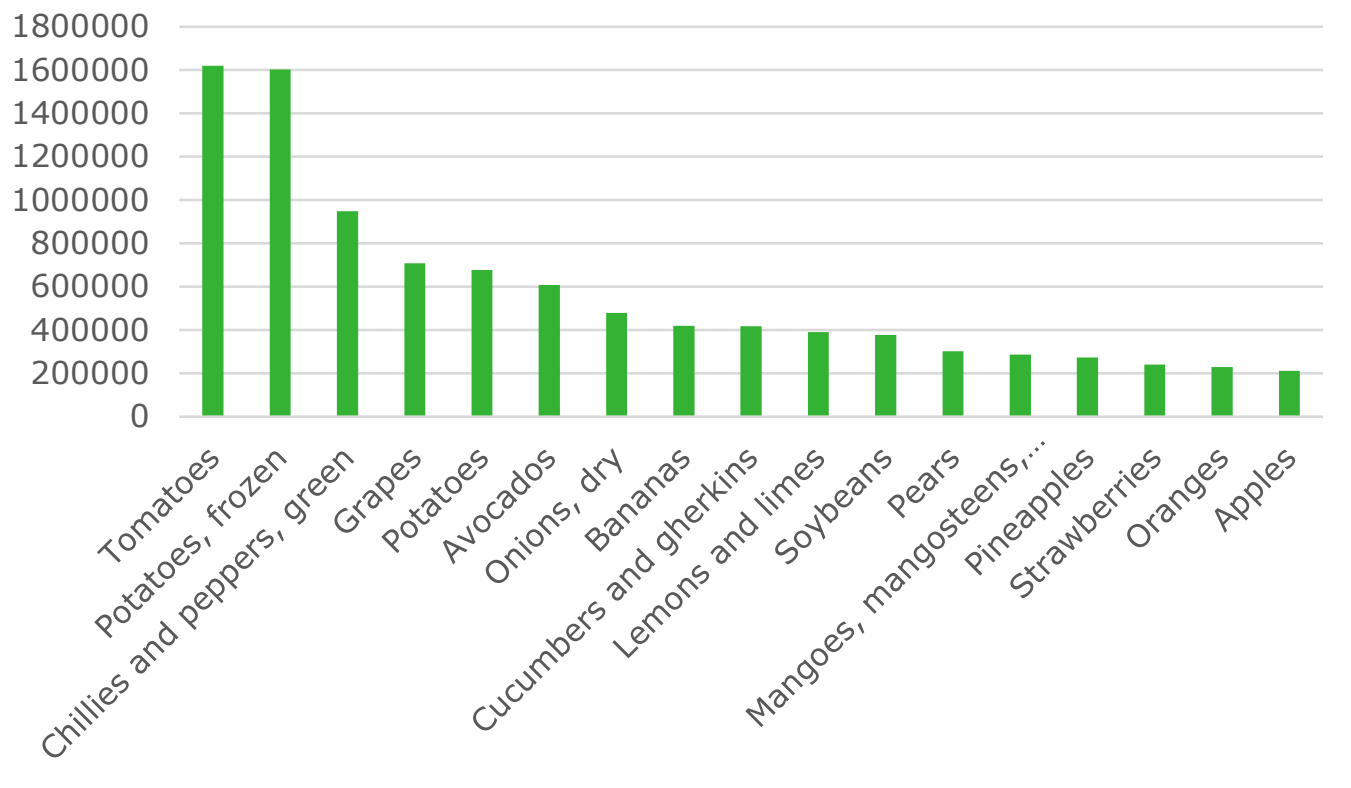

Figure 5. The major Dutch fruits and vegetables exports in 2016 (Source: CBS)

Value-wise, the Netherlands is the second largest exporter of fresh fruits and vegetables just next to Spain (Boon, 2015). The major fruits and vegetables that were exported by the Netherlands in 2016 are presented in Figure 5, where tomatoes, frozen potatoes and green chillies and peppers are the top-3 exported products.

The Netherlands are the largest players in flower exports who essentially dominate the global market with a market share up to $52 \%$. Colombia (15\%), Ecuador (9\%), Kenia (7\%) are the main competitors of the Netherlands but are still far away from its leading position. The tulip is the most exported Dutch flowers and the Netherlands is also an important exporter of fresh rose (Source: CBI Ministry of Foreign Affairs). Germany is the biggest importer of the Dutch flowers (Floribusiness, 2017).

TOP 10 Largest Players in Flower Exports

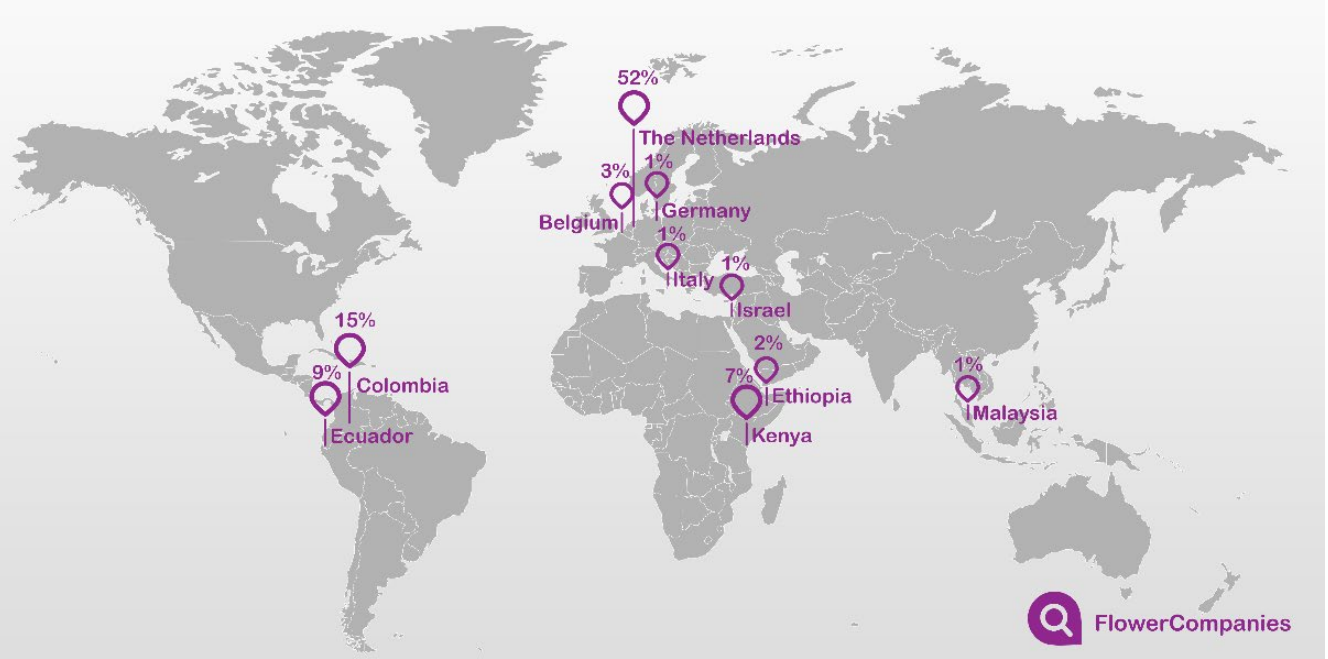

Figure 6. The world largest flower Exporters 2016 (Source: Weitjens (2016)) 


\section{Recent issues related to postharvest technology development in EU and the Netherlands}

\subsection{The new trends in the postharvest fresh produce chains}

There are several trends have been observed in the fresh produce chains. The first is the shifted focus on pure economic success to the improvement of sustainability. This brings about the pressures for reducing postharvest losses along the whole fresh produce chain. The second trend is that more and more postharvest technologies rely on the automated processes to allow the dynamic adjustments of some thresholds and values to enable the optimal use of existing technical receipts (e.g., dynamic temperature control, dynamic atmosphere control, dynamic packaging). The third trend is the embracing of the big data technologies where block chains have recently drawn the most attentions. All these trends will bring in enormous changes in the agro fresh sector and reshape the postharvest fresh produce chains to a significant extent.

\subsection{Postharvest technologies and management to prevent food losses}

Roughly one third of the food gets lost or wasted in the post-harvest phase and the post-harvest loss rates for fruits and vegetables can amount to as high as 50\% (FAO) (Also see Figure 7).

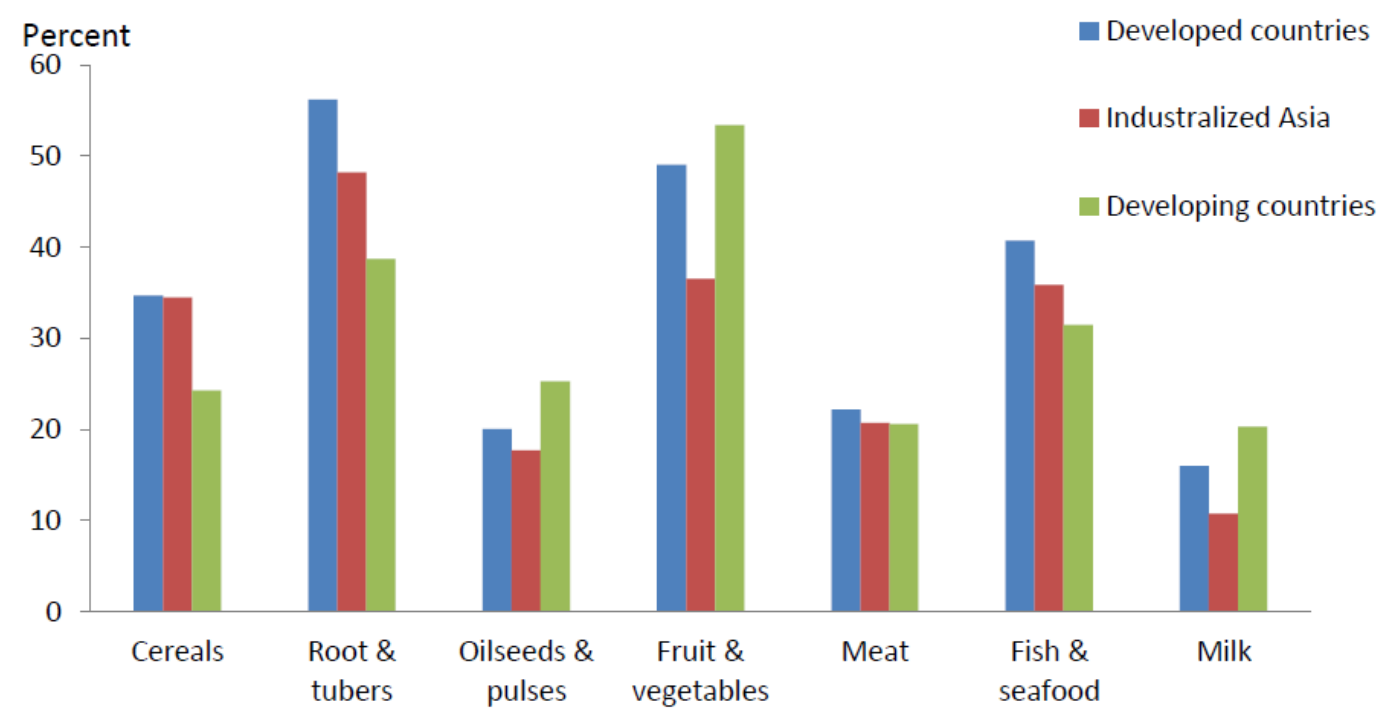

Figure 7. Food losses vary by commodity across countries (Source: Aulakh et al. (2013))

Post-harvest losses can happen in different stages of the fresh product supply chains ranging from onfield wastes to the wastes on the consumers' end. Aulakh et al. (2013) develop a framework to conceptualize the food loss processes in the post-harvest food chain (See Appendix A). In short, for each chain stage, there are a list of identified factors that can drive food losses, which determines the amounts of losses in different stages of the fresh chain (Figure 8). Figure 8 demonstrates the statistics for food losses by the stage of supply chain across countries. It shows that food wastes occur more at the pre-consumption stages for the developing countries while the developed countries suffer more losses at the consumption stage. The industrialized Asia countries stay in a "middle positon" between two extremes. 


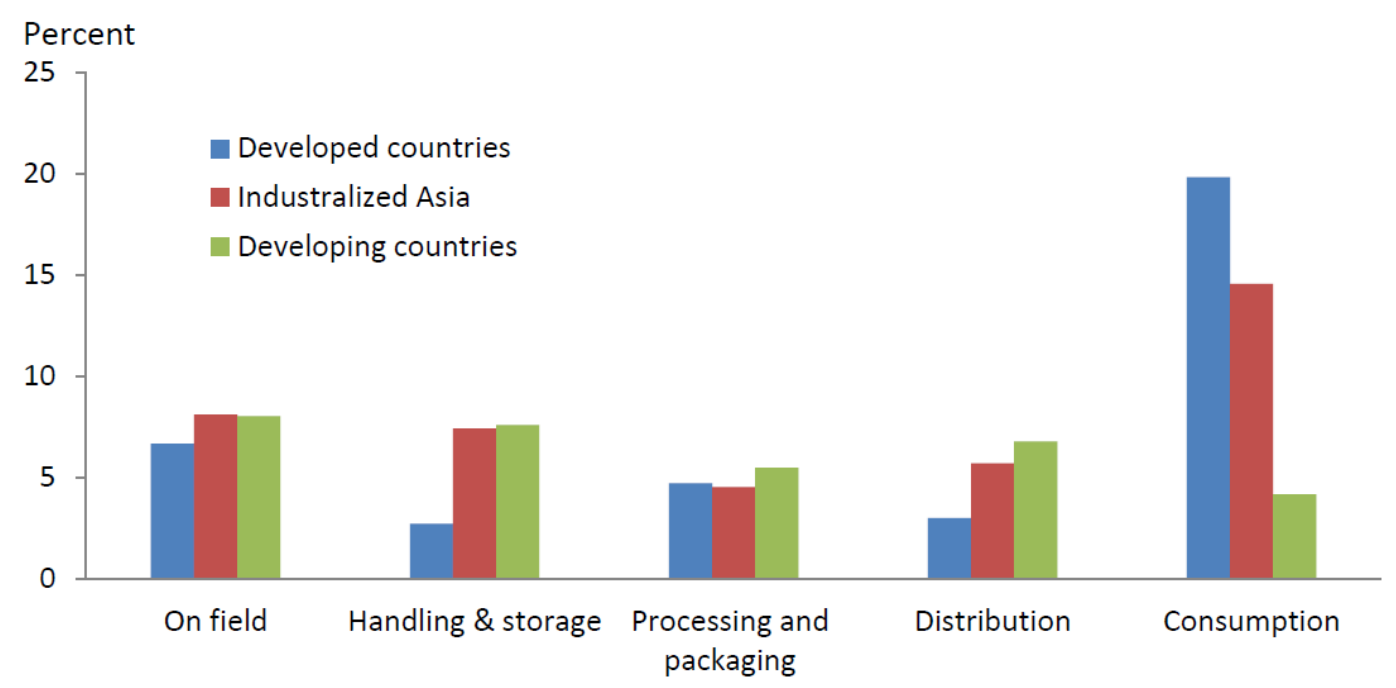

Figure 8. Food losses vary by the stage of supply chain across countries (Source: Aulakh et al. (2013))

Postharvest technologies which address the storage, packaging and handling of fresh horticultural products are the key to prevent postharvest losses. (Mahajan et al., 2014) conduct a review on the prevailing postharvest treatments of fresh produce (See Appendix B). They distinguish the postharvest treatments by physical treatments, chemical treatments and gaseous treatments. Physical treatments include heat treatment, edible coating, irradiation (Note: for the Netherlands and EU, coating and irradiation are hardly used). Hot water dip (HWD), saturated water vapour heat, hot dry air and hot, water rinse (HWR) with brushing are the typical heat treatment technologies (Schirra et al., 2000). Edible coating is a technology that creates thin layers of external coatings to cover the surface of fresh produce to enhance the waxy cuticle or as replacements for natural barriers where the produce cuticle has been removed (Dhall, 2013; Gol et al., 2013) (Table 1).

\section{Table 1. Summary of edible coating(s) used on fresh/fresh-cut fruit and vegetables} (Source: Mahajan et al. (2014))

\begin{tabular}{|c|c|}
\hline coating material & purpose of coating \\
\hline guar gum; pea / potato starch \pm potassium sorbate & antimicrobial \\
\hline candelilla wax-based & antimicrobial; antioxidant; quality \\
\hline soya bean gum; jojoba wax; glycerol and arabic gum & overall quality \\
\hline Shellac \pm Aloe vera gel & keeping quality \\
\hline soy protein; carboxymethyl cellulose & antioxidant; $\mathrm{H}_{2} \mathrm{O}$ barrier \\
\hline chitosan; zein & antioxidant; $\mathrm{H}_{2} \mathrm{O}$ barrier \\
\hline beeswax; coconut and sunflower oil & antimicrobial; antioxidant; quality \\
\hline pectin base; alginate; carboxymethyl cellulose & antioxidant; $\mathrm{H}_{2} \mathrm{O}$ barrier \\
\hline chitosan; methyl cellulose & antimicrobial; antioxidant; $\mathrm{O}_{2} / \mathrm{CO}_{2} / \mathrm{H}_{2} \mathrm{O}$ barrier \\
\hline soy protein; carboxymethyl cellulose & antioxidant; $\mathrm{H}_{2} \mathrm{O}$ barrier \\
\hline pectin base & overall quality \\
\hline Aloe vera gel & overall quality \\
\hline agar; chitosan; acetic acid (combined) & antimicrobial; $\mathrm{O}_{2} / \mathrm{CO}_{2}$ barrier \\
\hline whey protein; rice bran oil & $\mathrm{H}_{2} \mathrm{O}$ barrier; overall quality \\
\hline chitosan & overall quality \\
\hline sucrose-polyester based & $\mathrm{H}_{2} \mathrm{O}$ barrier; antioxidant activity \\
\hline alginate and gellan based & $\mathrm{O}_{2} / \mathrm{CO}_{2} / \mathrm{H}_{2} \mathrm{O}$ barrier \\
\hline
\end{tabular}


Irradiation technology that exposes food to radiant energy is used to destroy bacteria, moulds and yeasts, which cause food spoilage (Farkas et al., 2014). It helps to reduce storage losses, extend shelf-life and improve parasitological and microbiological safety of foods (Farkas et al., 2014). Irradiation technology, however, is not relevant for EU.

Chemical treatments include antimicrobial and anti-browning agents, nitric oxide and sulfur dioxide and the gaseous treatments include ozone, ethylene, 1-Methylcyclopropene, controlled atmosphere storage and modified atmosphere packaging (Mahajan et al., 2014).

In a broader sense, other than the conventional postharvest treatments on fresh products, postharvest technologies can also refer to cold chain logistics, which consists of precooling, refrigerated transport and cold storage (Wu et al., 2018). The precooling process is largely absent in the developing countries which cause big quality problem at the end of the chain.

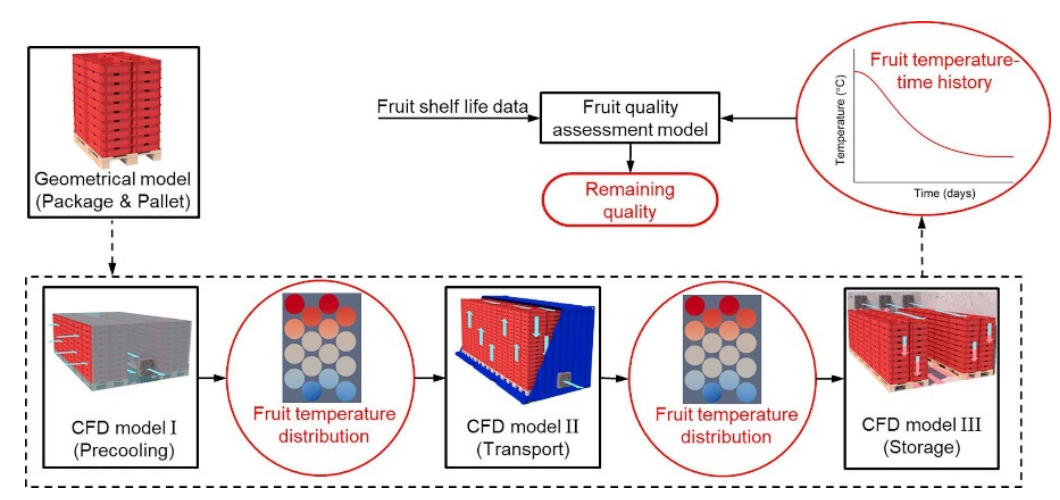

Figure 9. The Virtual Cold Chain (VCC) method illustrated for a typical cold chain consisting of precooling, refrigerated transport and cold storage (Source: Wu et al. (2018))

In general, the international community more and more recognizes the crucial role that postharvest management expertise plays in establishing sustainable global food chains. As the expertise leader, the European Union including the Netherlands have made a lot of efforts in improving the post-harvest management both in the home countries and in the developing world.

European Union pays a lot of attentions to equip the farmers with advanced post-harvest technologies. For example, it finances the NARA project for agriculture and post-harvest training with the aim to improve the professionalization of European young farmers specialized in fruit and vegetables growing (Source: EIP-AGRO) (Also see Appendix C).

Another EU project that is related to the postharvest management is the "EU FP7 Veg-i-Trade" project. It investigates the pre and post-harvest practices influencing microbiological quality and safety of fresh leafy vegetables (e.g. lettuce, spinach, escarole, cabbage).

The RE-Pear project financed by EU adopts an integrated chemical-free pest management approach aiming to develop and redact standardized postharvest management and control practices guidelines for pears to avoid possible unevenness within EU domestic market.

The European union also funds the projects that help the farmers of the developing countries to improve their post-harvest management skills. For examples, it supports the project that trains the farmers on post-harvest management of sorghum, groundnut and rice in the Bahr el Ghazal Region (Source: Post harvest management practices - Europa EU). EU also invests in organizing the international partnership to reduce postharvest losses in sub-Saharan African by helping to develop and expand the African Postharvest Losses Information System (Source: the European commission website).

In the Netherlands, the Postharvest Network, a network of Dutch specialized companies, knowledge institutes like Wageningen University and the Dutch Ministries of Foreign and Economic Affairs, was launched on December 4, 2014 (Source: from the food \& Business Knowledge Platform). It is with the mission to reduce postharvest losses by implementing proven and practical solutions in the fresh 
product chain. It has a strong international orientation that aims to apply Dutch postharvest knowledge to food loss prevention in the developing countries. Since the fresh product supply chain become more and more global, the success of the business depends increasingly on the high performances of all the countries embedded in the chains. Moreover, to really consolidate a central role in the global agro product chain, the Netherlands should become the main postharvest expertise providers in the world. Many Dutch companies have been deeply involved in postharvest knowledge transfer to other countries, which significantly increases the Netherlands' influences in the global fresh produce chains. For example, the Dutch company Kenlog, a pivotal participant in a network of specialized companies in the complete food and floriculture chain, exports postharvest skills to Viet Nam to help the Vietnam farmers to improve their postharvest management (Source: the website of Kenlog)

Wageningen University \& Research (WUR) as one of the best Agricultural Research institutes of the world is a major Dutch postharvest knowledge creator and contribute significantly to the Dutch leading position in this area. In the next section, we will present several impactful postharvest technology R\&D carried out by WUR.

\subsection{A list of postharvest technology R\&D projects carried out by WUR}

In this section, a list of major postharvest R\&D projects carried out by WUR (essentially by Wageningen Food \& Biobased Research) are introduced and grouped into three categories.

It is necessary to realize that this is just a small part of the total projects. Currently there are around 100 similar type of projects being carried out by by Wageningen Food \& Biobased Research, but due to the confidentiality issue, we cannot list them here.

\subsubsection{Controlled Atmosphere}

\section{CATT}

CATT is the abbreviation of Controlled Atmosphere Temperature Treatment. It is a strong and sustainable alternative of the traditionally chemicals-based solution to combat pests (e.g. insects, nematodes, mites) on post-harvest plant products. It was developed by Wageningen UR in cooperation with grower organizations due to the worldwide phase-out of methyl bromide.

Controlled Atmosphere (CA) is a well-developed and proven postharvest technology widely used in fruit and vegetable storage. In $\mathrm{CA}$, lowered $\mathrm{O} 2$ and elevated $\mathrm{CO} 2$-compared to air- restrict respiration of plant material, but also of pests. Heat treatment -usually used for dry goods such as packing wood/pallets- increases pest metabolic rates and results in $100 \%$ pest mortality, (e.g. ISPM 15, >30 min $56^{\circ} \mathrm{C}$ ). However, it is difficult to apply such heat treatment to the live plant products because the live plant materials can not suffer the high temperature as well. To tackle such a problem, CATT is introduced with less severe temperature treatment to lower the respiration but increase metabolism. This new technology can effectively control pest but not bring in unacceptable loss of plant material quality.

Meanwhile first screenings of CATT potential for a range of products and pests was performed with promising results: 
Table 2. The first screened products and pests for CATT potential (Source: WFBR factsheets)

\begin{tabular}{l|l|l|l}
\hline pest name & & plant products \\
\hline Chitwoodi & Meloidogyne chitwoodi & & seed potatoes \\
\cline { 1 - 2 } Western Flower Thrips & Frankliniella occidentalis & & Chrysanthemum \\
\hline White fly & Bemisia tabaci & tomato on the vine \\
\hline Wheat curl mite (tulpengalmijt) & Aceria tulipae & tulip bulbs \\
\hline Tomato leaf miner & Tuta absoluta & apples, pears \\
\hline Fruit moth & Cydia pomonella &
\end{tabular}

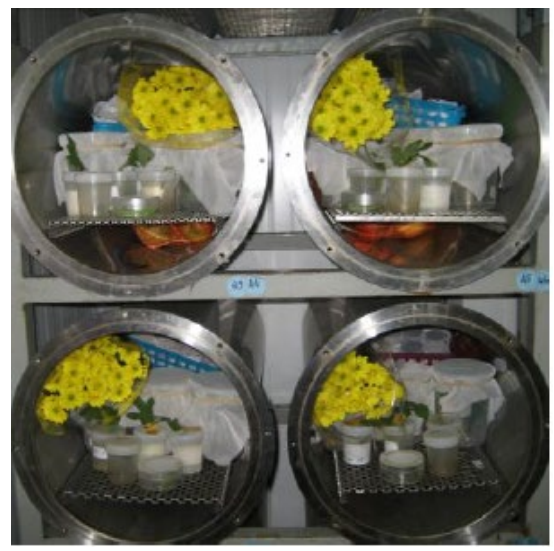

Figure 10. Screening of products and pests for CATT potential (Source: WFBR factsheets)

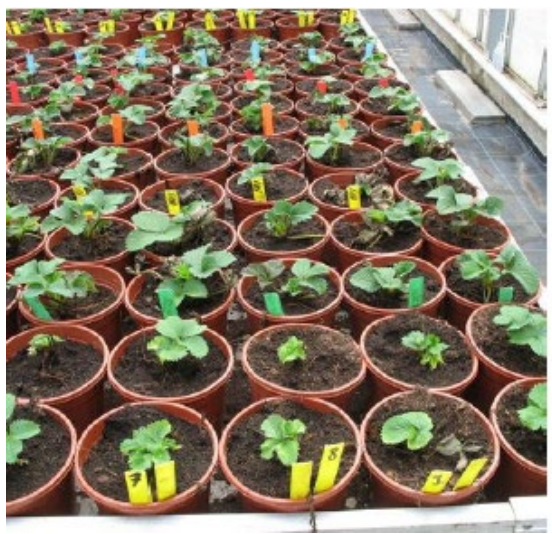

Figure 11. In development of CATT screening of effects on plant quality is essential (Source: WFBR factsheets)

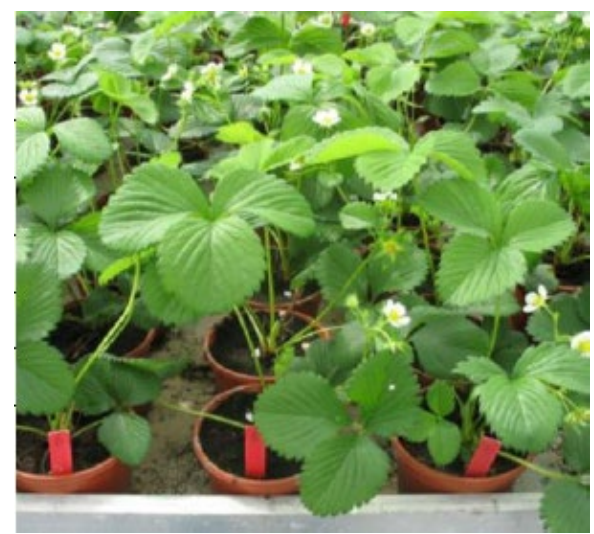

Figure 12. Excellent plant quality after CATT at $35^{\circ} \mathrm{C}+$ a period at $40^{\circ} \mathrm{C}$ (Source: WFBR factsheets)

\section{Dynamic Control of Respiration}

Apples and pears are normally stored under fixed oxygen conditions. As an alternative Wageningen Food \& Bio-based research developed together with Van Amerongen CA technology a new and 
revolutionary storage system based on the Respiratory Quotient (RQ) of the product in the storage room. It allows continuous measurement of RQ based on the total product load of the Controlled Atmosphere room. The system measures the RQ by (short) periodical shutting down all conditioning of a ULO room while monitoring $\mathrm{O} 2$ and $\mathrm{CO} 2$ evolution. It enables the user a more reliable measurement to set the optimal oxygen condition in storage.

This new system is combined with a full control of cooling and CA-systems which responds to the total product load in the storage room to guarantee safe and lowest possible oxygen concentration. This system can improve the fruit quality (including the tastes and firmness) and enlarge its storage and shelf-life potential. It saves the energy consumption of cooling system by $50 \%$.

\section{The compact \& dry project}

The compact and dry project is concerning "the dry transport of flowers" to achieve cost-effectiveness without losing flower qualities.

To ensure a better vase life, conventionally, most European wholesalers and retailers receive their flowers in water. The researchers from Wagningen Food \& Biobased Research develop the dry flower transport technology as a reliable alternative for in-water flower transport. The dry transport leads to fewer Botrytis infections and makes no difference in vase life compared to the traditional in-water shipments. In terms of flower outlooks, the dry-transport flower may look less hydrated at arrival. Most European wholesalers and retailers are used to receiving their flowers in water, which is a low care service concept. Transport in water is generally believed to contribute to a better vase life. Wageningen UR Food \& Biobased Research has demonstrated, however, that dry transport is a good alternative. Real-life studies led to fewer Botrytis infections and made clear there was no difference in vase life between dry or pre-watered flowers and flowers conventionally shipped in water. Flowers may look less hydrated at arrival, but they will get back to normal conditions after having been put back into water for a few hours.

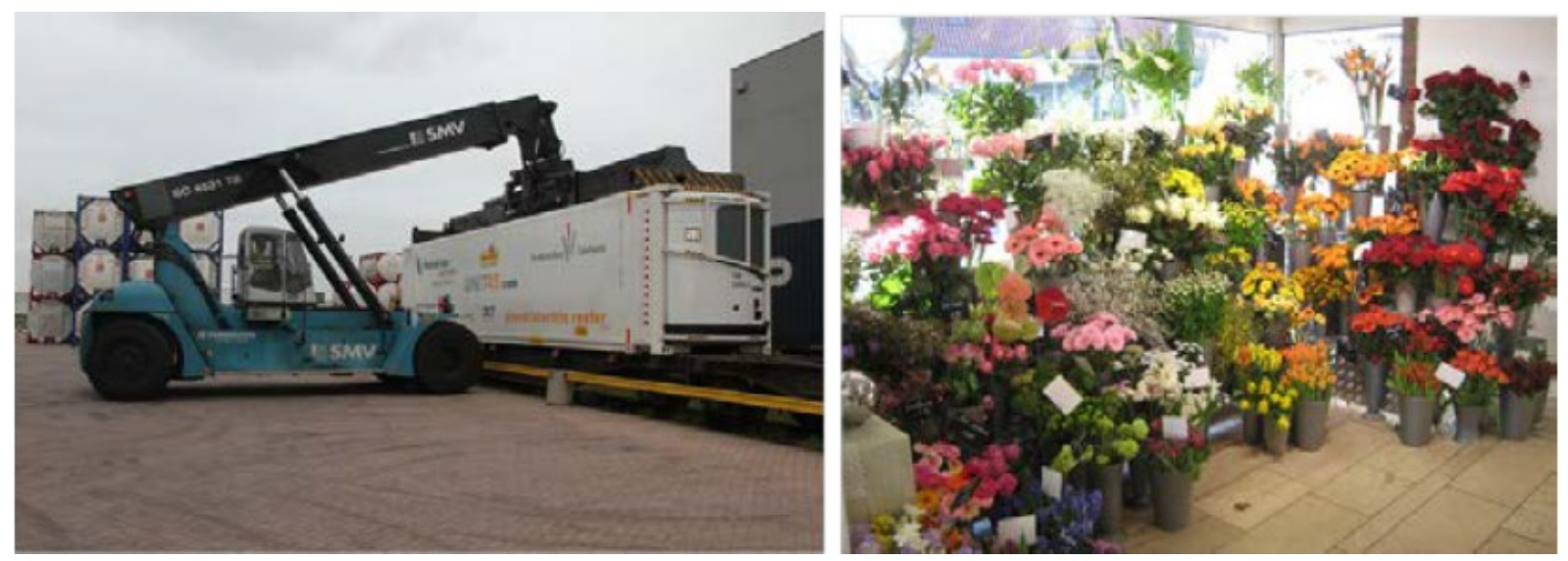

Figure 13. The dry transport of flowers (Source: WFBR factsheets)

The compact nature of the dry flowers has a significant implication to logistic costs. The traditional way of flower transportation bears skyrocketing high costs. As a comparison, the dry flower transport is more cost-effective and sustainable because more stems can be carried per container (50\% more load possible), which results in lower per stem transport costs and $\mathrm{CO} 2$ emissions. Food \& Biobased Research has made transport protocols for transporting rose, tulip, carnation, chrysanthemum, lilium, alstroemeria in the most dry and compact way. Knowledge concerning other varieties of cut flowers is also on hand.

The compact \& dry project demonstrate that the cost-saving potential with dry transport is between 20 to $50 \%$. Other benefits of this innovation include lower CO2 emission, longer vase life.

\section{Sea transport of rose}

For the long distance shipments of rose (e.g. intercontinental transportation), air freight is the conventionally adopted transport mode. Wageningen Food \& Biobased Research investigates the feasibility of using sea transport as an alternative for the air transport. 


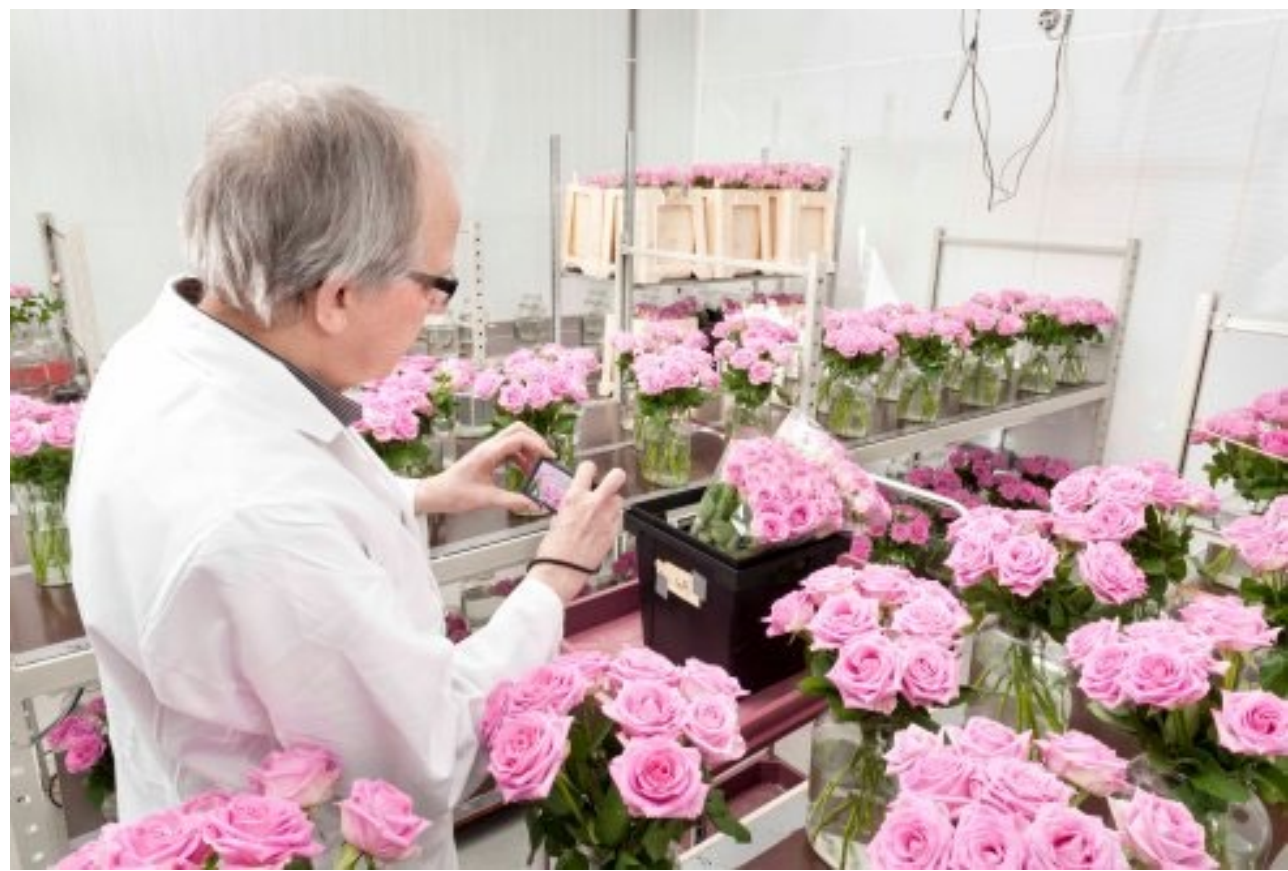

Figure 14. The rose transported by sea freight (Source: WFBR website)

From repeated tests for the roses shipped from Kenya to the Netherlands, it demonstrates that roses that spend weeks by the sea transport with remotely controlled air-conditioned reefer containers can just retain their quality as well or even have a better quality than the ones shipped by air freight. This is an encouraging finding because the air-borne shipments are not only expensive but also environmentally unfriendly. The sea transport can reduce the $\mathrm{CO} 2$ emission by $87 \%$ compared to air transport, which bring in enormous benefits to the environment.

\subsubsection{Infrastructure related}

\section{Quest}

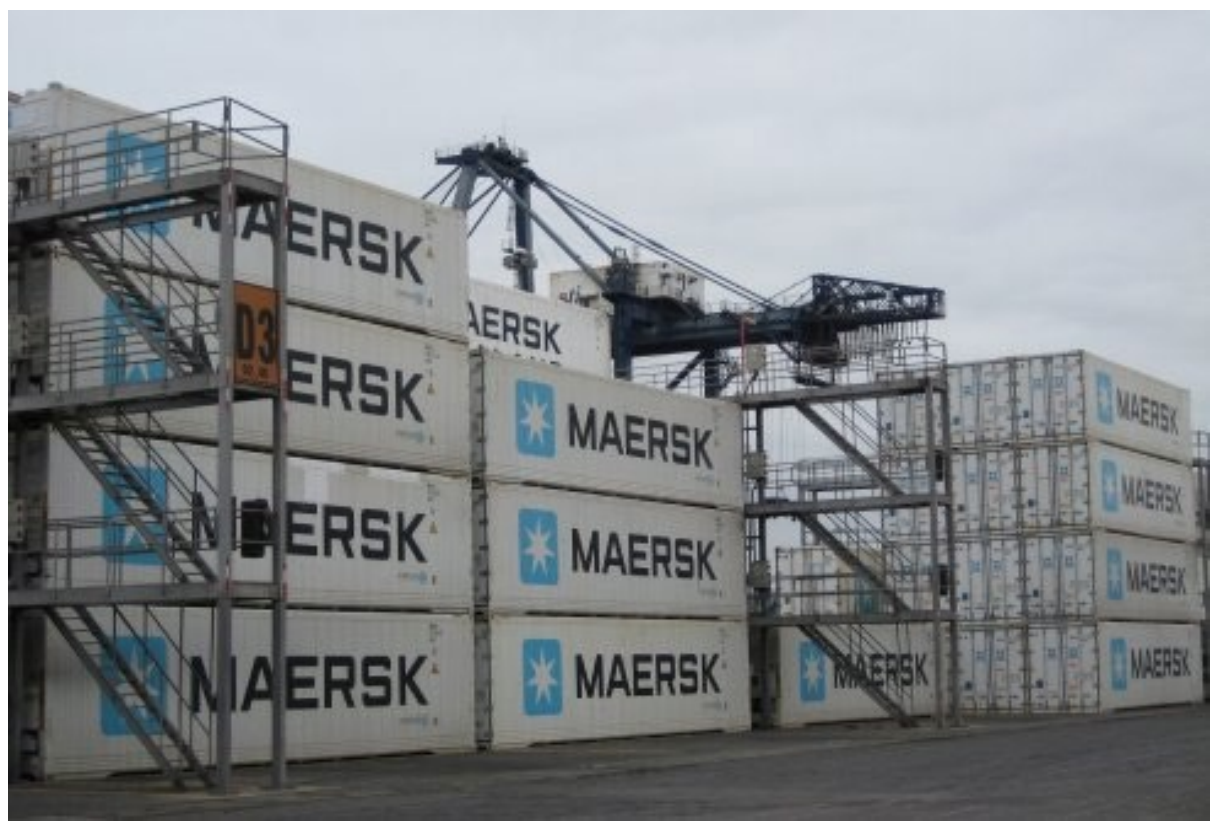

Figure 15. The Maersk reefer containers with the Quest technology (Source: WFBR website)

Quest stands for Quality and Energy in Storage and Transport. It is an innovative control methodology that applies to the container refrigeration units with the profound understanding of dynamics of (micro-) climate in reefer containers. It was developed by Wageningen Food \& Biobased Research, the Maersk Line and reefer-unit manufacturers Carrier Transicold. This new technology embodies a well- 
thought-out method for (transport) refrigeration units with the computer model to simulate climate control strategies. It creates a dynamic temperature curve by switching off/on the cooling systems. Namely, the internal air circulation (i.e. the fan speed) is adjusted to the actual heat load. The compressor operation is optimised for operational state. By doing so, it reduces energy consumption of reefer units by $65 \%$ (in the second phase of the project: Quest II) without compromising the produce quality. It also reduces the carbon footprint of the international food supply chains. With this technology, proper precooling of cargo prior to stuffing becomes less important.

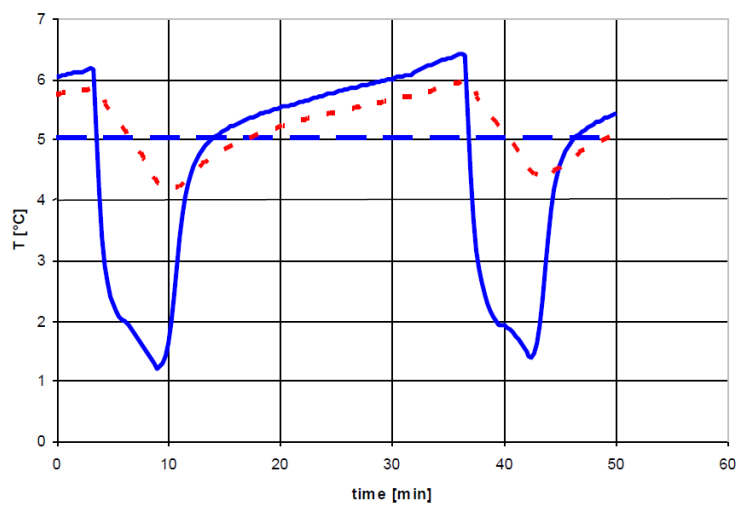

Figure 16. The typical temperature curve in Quest II (Source: Lukasse et al. (2013))

Table 3. Average steady state temperature gradient in reefer containers observed over hundreds of trial shipments within the Quest II project (Source: Lukasse et al. (2013))

\begin{tabular}{|l|l|l|l|l|}
\hline $\begin{array}{l}\text { type of } \\
\text { control }\end{array}$ & $\begin{array}{l}\text { warmest - } \\
\text { coldest steady } \\
\text { state cargo } \\
\text { temp. }\left[{ }^{\circ} \mathbf{C}\right]\end{array}$ & $\begin{array}{l}\text { avg. USDA - } \\
\text { setpoint } \\
\text { during steady } \\
\text { state }\left[{ }^{\circ} \mathbf{C}\right]\end{array}$ & $\begin{array}{l}\text { duration of } \\
\text { temperature } \\
\text { pulldown in } \\
\text { banana shipments } \\
\text { [days] }\end{array}$ & $\begin{array}{l}\text { avg. no. of defrosts } \\
\text { per day in shipments } \\
\text { at setpoints 3.5 } \\
{ }^{\circ} \mathbf{C}\left[{ }^{\circ} \mathbf{C}\right] \text { with defrost } \\
\text { interval set at 'auto' }\end{array}$ \\
\hline Quest II & 1.0 & 0.3 & 0.52 & 0 \\
\hline Quest I & 1.0 & 0.8 & 0.45 & 0.6 \\
\hline non-Quest & 0.8 & 0.6 & 0.69 & 1.0 \\
\hline shipments & 48 & 48 & 18 & 6 \\
\hline
\end{tabular}

\section{Floor cover in the refrigerated container}

Fruits quality preservation during the maritime refrigerated transportation relies heavily on the accurate temperature management. In the ideal situation, the temperature in the refrigerated containers should be the same everywhere as the set temperature. However, due to poor air flow distribution, the door-end temperatures are always higher, which can have a negative impact on fruit quality.

The researchers from Wageningen Food \& Biobased Research (Lukasse and Staal, 2016)investigate the possibility of covering the T-bar floor to improve temperature distribution in the refrigerated container. 

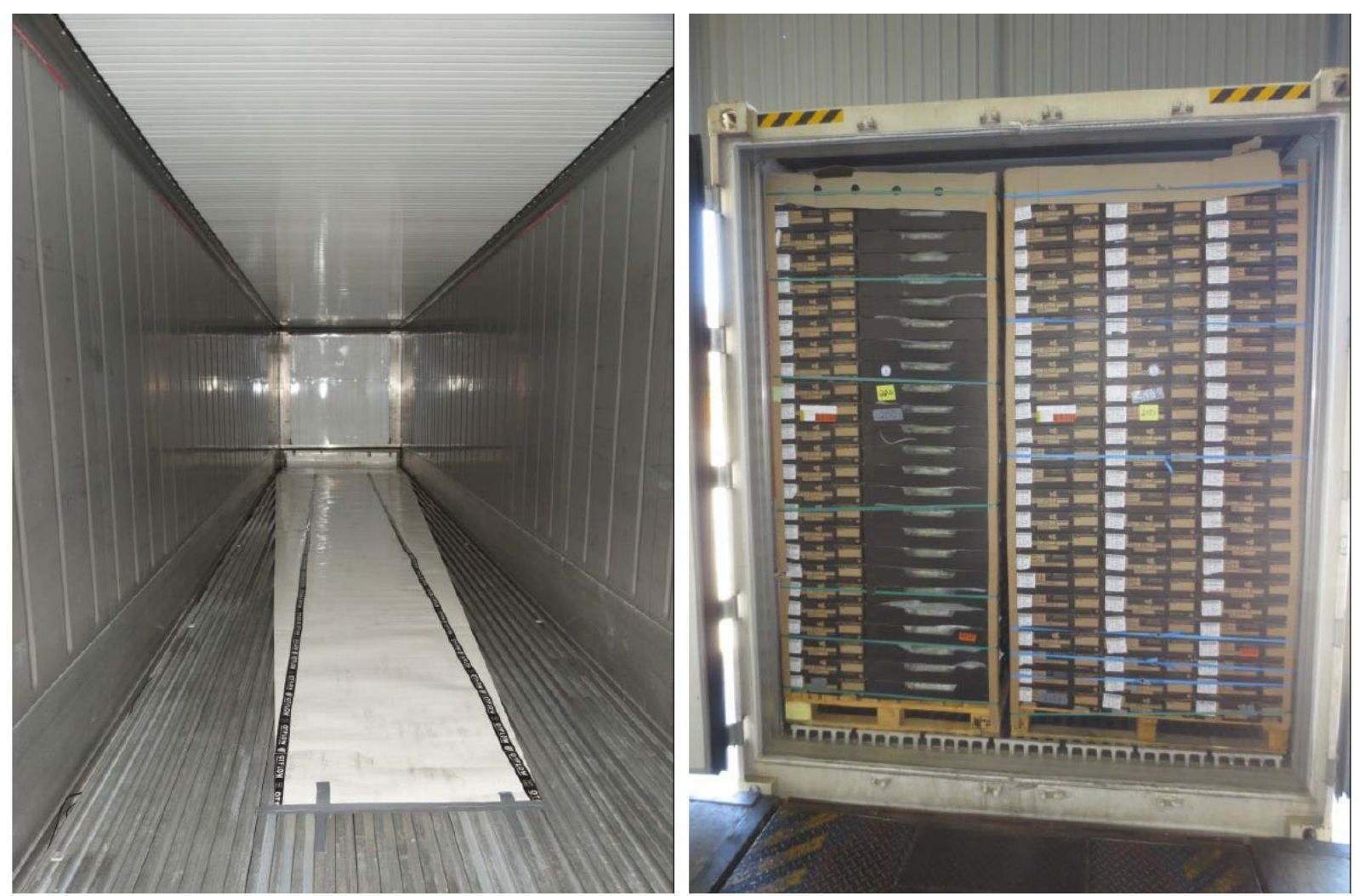

Figure 17. Floor cover installed in a reefer container and the trays on pallets in the container (Lukasse et al., 2017)

They found that the best T-bar floor cover is a trapezoid-shape floor cover:

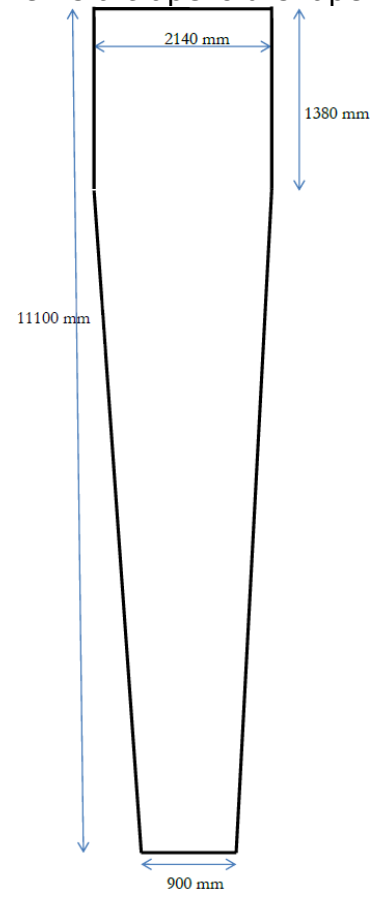

Figure 18. The sketch of the trapezoid-shape floor cover (Lukasse et al., 2017)

A field experiment with table grapes that was done in a commercial container from South Africa to the Netherlands shows a clear positive effect of the trapezoid-shape floor cover on the even distribution of the temperature. The floor cover reduces the average difference between warmest and coldest temperature in the trays by approx. $30 \%$.

\section{Cool}

Cool is a mobile research facility for postharvest technology that were co-developed by Wageningen Food \& Biobased Research and Fotein - specialists in controlled-atmosphere technology. 


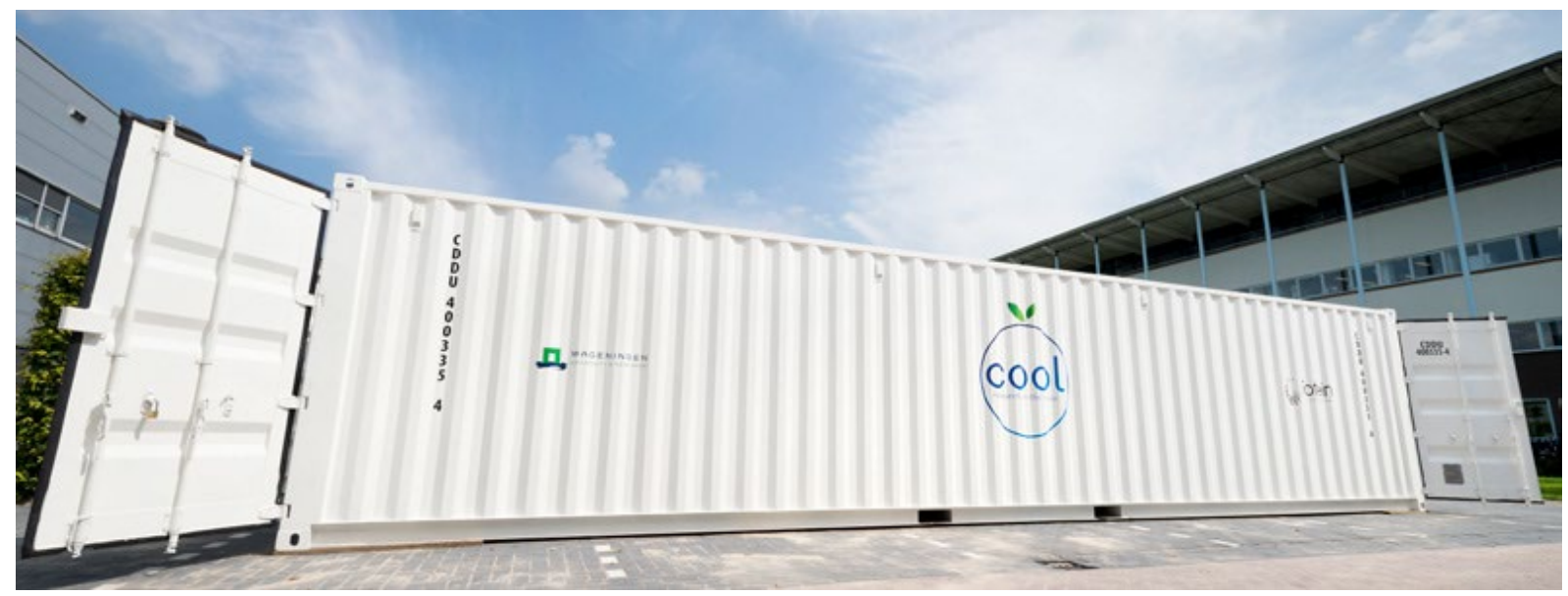

Figure 19. The mobile research facility for postharvest technology: Cool (Source: WFBR factsheets)

Cool is a ultramodern research facility that has ten adjustable climate chambers as well as other measuring devices and control equipment.

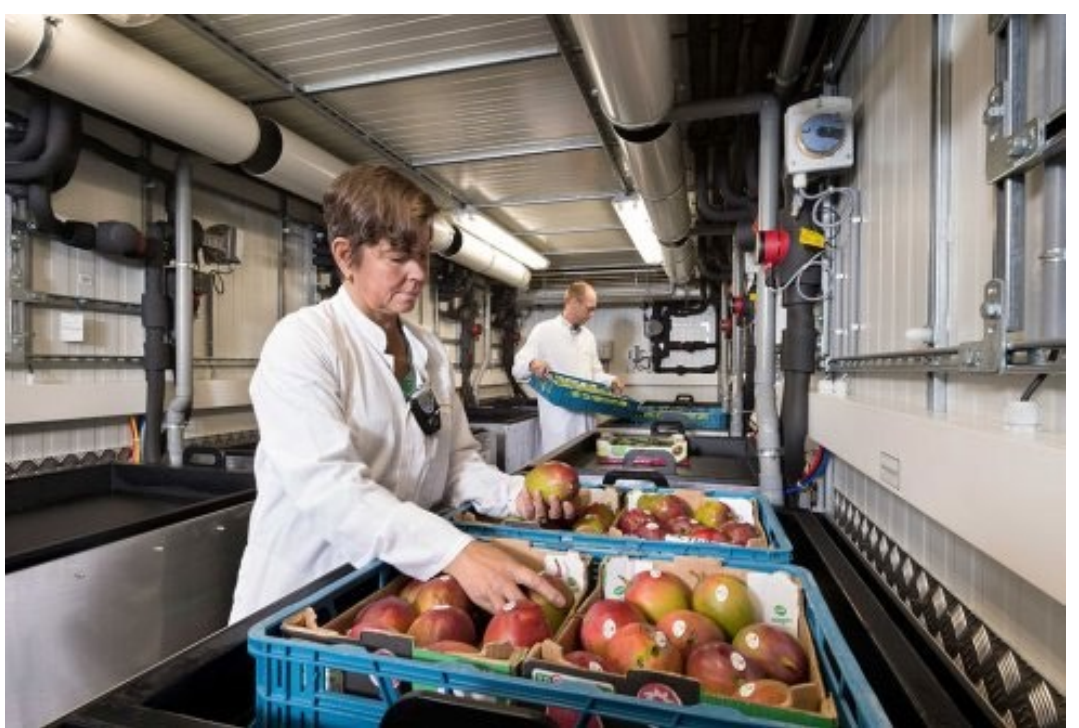

Figure 20. The inner of the Cool facility (Source: WFBR factsheets)

With Cool, the starting quality of the fruit and vegetables can be fast and reliably evaluated. It can also provide customized storage conditions that are according to the features of different products whose quality decays are constantly monitored.

The mobile nature of Cool enables research institutes and companies to carry out independent research into the quality of local perishables without the location constraint.

\subsubsection{Packaging}

\section{Dynamic Modified Atmosphere packaging (DMAP)}

The dynamic modified atmosphere packaging is a technology that was developed by Wageningen Food \& Biobased Research to improve the shelf life of the stored conference pears which includes firmness, shriveling, colour, taste and microbial decay of the pears.

Conference pears after storage can have a problem during the distribution. The pears tend to ripen too fast to become the "too soft" fruits, which can hamper the sales because the bad presentation. With the MAP technology the conference pears after previous long-term CA storage are packed in semi-air tight packaging. It uses the respiration of the fruits to induce the $\mathrm{CO} 2$ and $\mathrm{O} 2$ concentration alteration 
to reduce the ripening speed of the packed pears through flushing with right gas mixture at the moment of packaging.

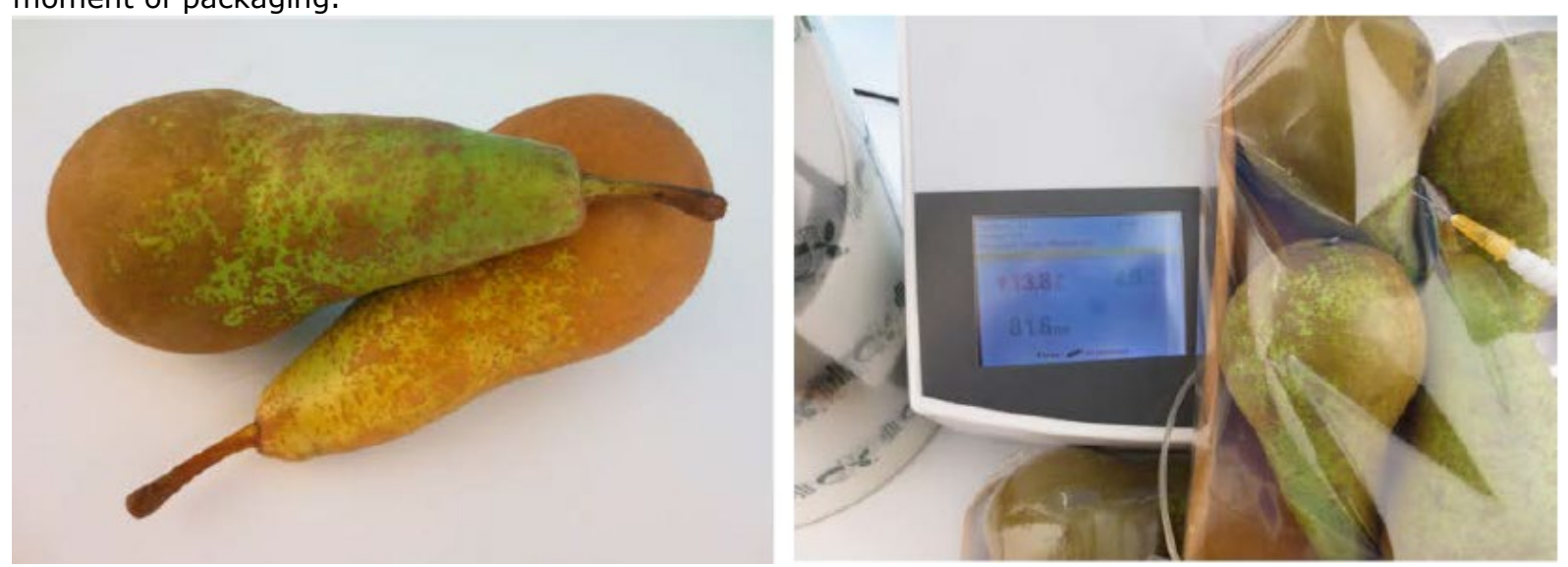

Figure 21. The pears with the modified atmosphere packaging (Source: WFBR factsheets)

MAP can be seamlessly embedded in the current foils and packaging systems. With MAP, the quality of the pears is improved during the distribution and the shelf life of the product is enlarged. The better presentation of the pears can better fit consumer taste preferences and convenience.

\section{PicknPack}

The PicknPack project develops the flexible food packaging system which is a flexible robotized production line to access quality and pack fresh and processed food products.

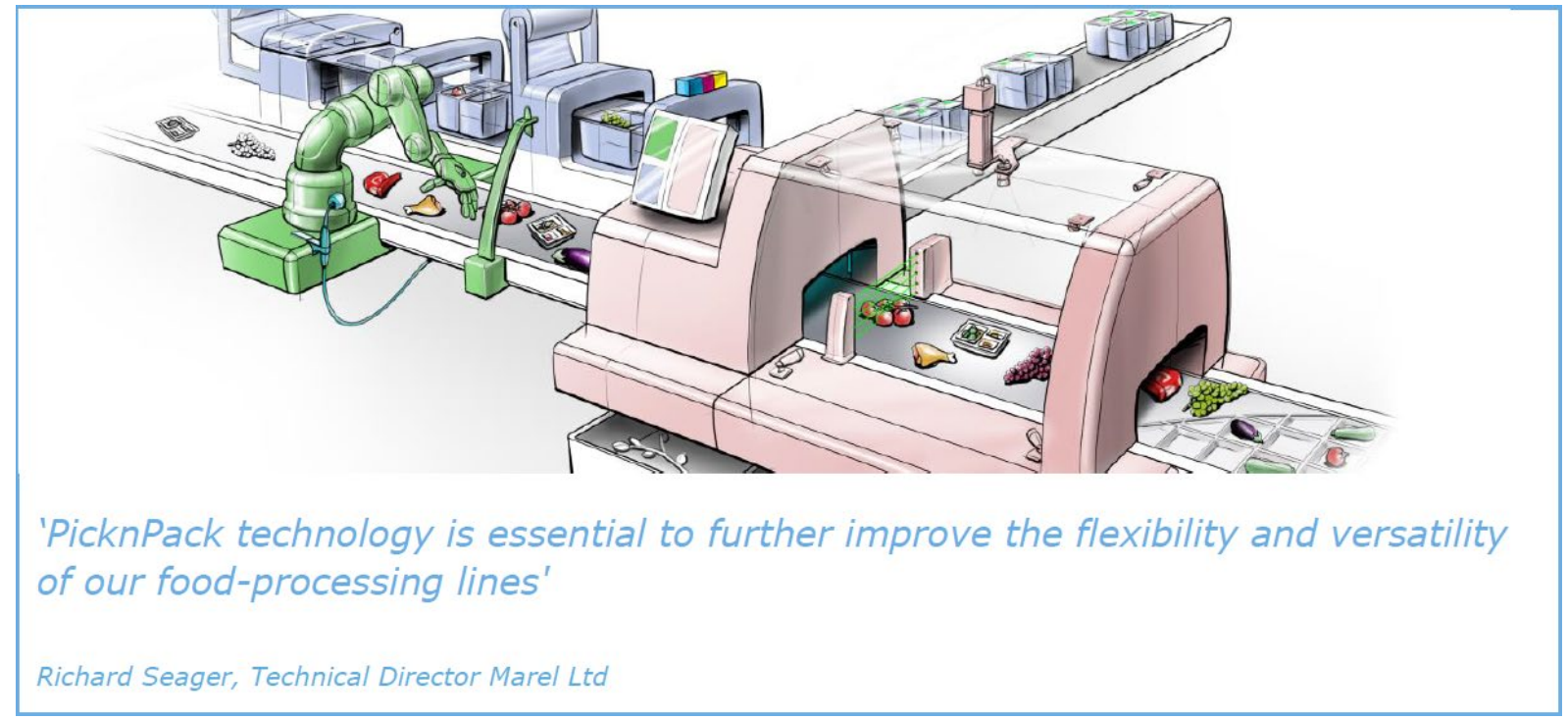

Figure 22. The flexible food packaging system (Source: WFBR website)

This system includes three closely coordinated modules:

- a sensing module that assesses quality of the individual or small batch products before or after packaging;

- a vision controlled robotic handling module that picks up and separates the product from a harvest bin or transport system and places it in the right position in a package;

- $\quad$ an adaptive packaging module that can accommodate various types of packaging with flexibility in terms of package shape, size, product environment, sealing and printing.

This robotic flexible system enables automated quality assessment. Food products are inspected using color and hyper-spectral cameras combined with 3D sensing techniques. Advanced computer-vision algorithms are developed to analyse the color and shape properties. Machine-learning techniques together with expert knowledge are used to determine the quality of the product.

The robotic packaging technique can deal with difficult-to-handle products which have a complex shape (e.g., vine tomatoes) or are delicate (e.g., mangos). With the help of the computer-vision methods, the product is sorted and placed in the appropriate package determined by its quality property and weights. 
This new system can improve efficiency of the product assessment, sorting and packaging, and increase the economic values of the products. The automated quality assessment module makes the quality assessment more objective.

\section{Tomato leaves-based packaging}

To optimize tomato production, tomato leaves need to be cut off from the tomato plant. Traditionally, a huge amount of leaves (1 ha ground can produce 1 ton tomato leaves per week) were wasted with a low value application.

Tomato leaves are actually valuable biomasses which are full of fibers that could be used as packaging material. The researchers from Wageningen Food \& Biobased Research come up with an initiative idea of packing tomatoes in trays made from their own leaves. This innovative concept can help to increase the added value of the horticulture products as well as the sustainability of the horticulture sectors.
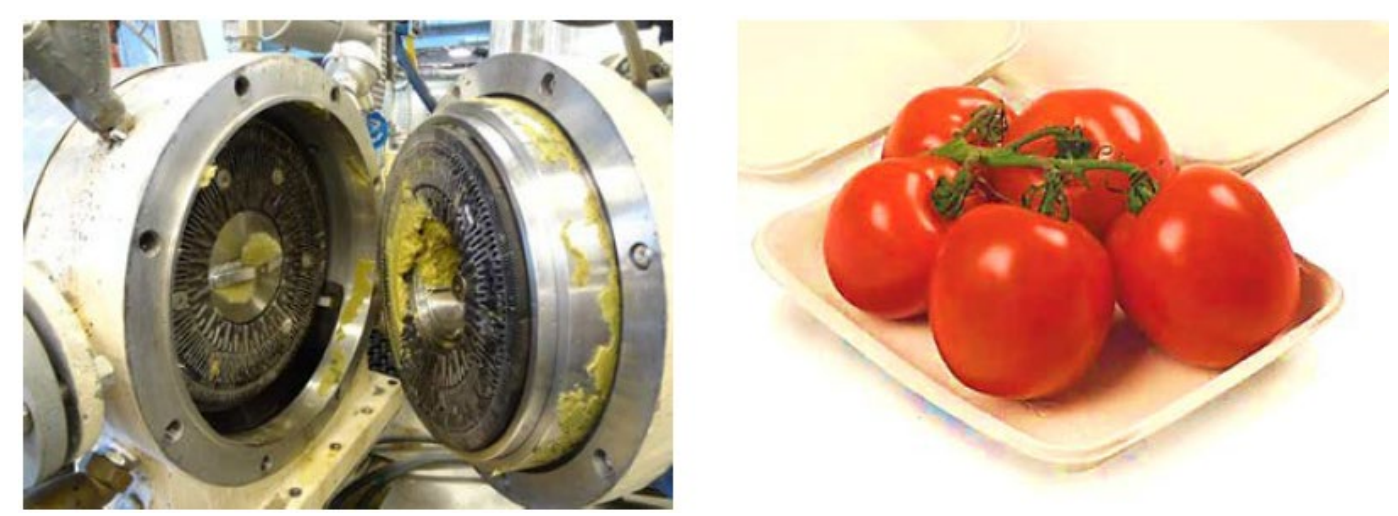

Figure 23. Tomatoes packaged in their own leaves (Source: WFBR factsheets)

Experiments showed that the performance of the trays made from the tomato leaves are absolutely comparable to the ones made from the $100 \%$ recycled papers.

With this technology, a new product and market combination with added value may be created. Less wastes and more sustainable process can bring in good business images. 


\section{Smart chain}

\subsection{Basic concept}

"Smart chain" or in a more accurate term "smart supply chain" is a concept in vogue but has no universally accepted definition yet (Gilmore, 2010). IBM defines the smart chain of the future more from a technical point of view (so do many other definitions) that the smart chain needs to be instrumented, interconnected and intelligent (For details: see Appendix D). According to IBM (Gilmore, 2010):

- Instrumented: Supply chains will be supported by pervasive data collection networks that provide real-time visibility; pallets will "report if the wind up in the wrong place.

- Interconnected: We will have system-to-system integration up and down the supply chain, not only to trading partners but to machines and inventory (shop floor to top floor).

- Intelligent: We will achieve better supply chain decision-making through advanced analytics and next generation optimization software.

This definition is obviously developed for the industrial product chain.

In the context of fresh agro products, Wageningen Food \& Biobased Research's version of "smart chain" is the one that can enable continuous predication and monitoring of product qualities to provide better and more detailed information to reduce losses, extend shelf life and facilitate quality guarantees. Therefore "quality preservation" is the core of the smart fresh chain which should combine temperature monitoring with the recent history of the product (e.g., growth data) and quality loss models. Such a combination makes unknown to known and deliver more insights into product quality than only monitoring temperature in the chain. As a result, clients can receive products with a uniform and stable quality that can help to improve profit margin and reduce wastes.
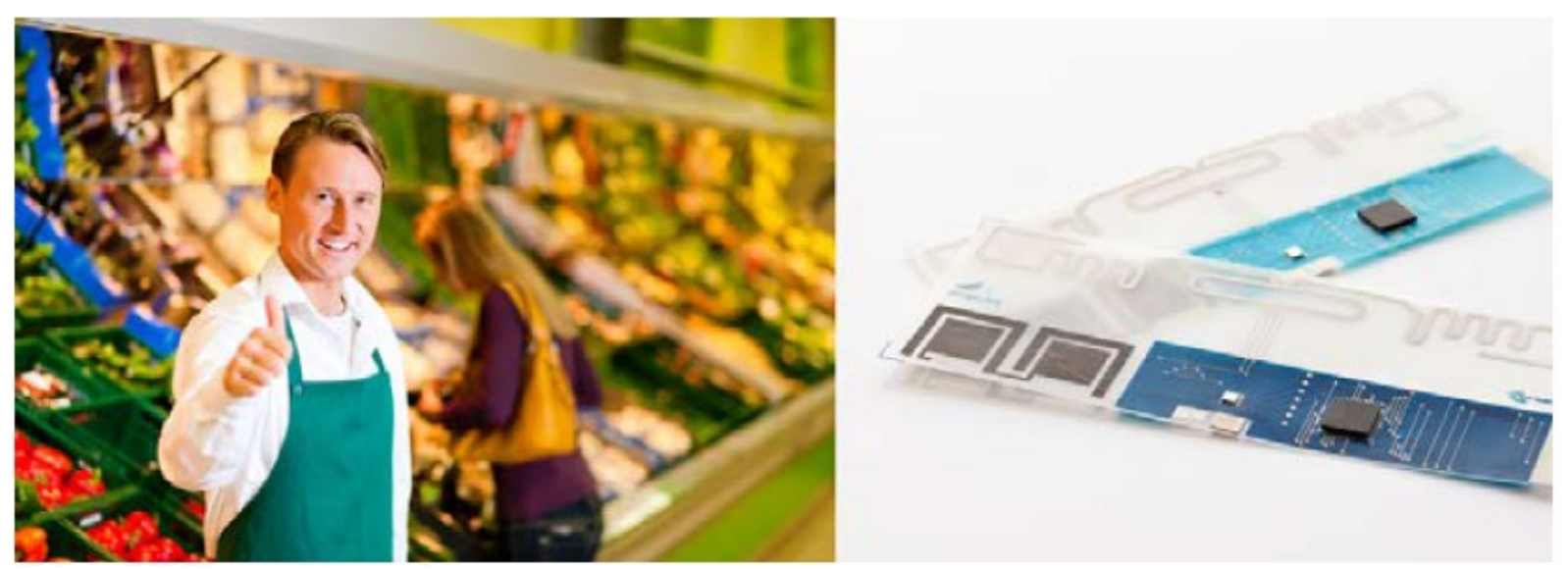

Figure 24. Smart fresh produce chains improve clients' satisfaction (Source: WFBR website)

Although the primary aim of smart chain is to preserve quality, it is also necessary to consider the trade-offs between quality and supply chain costs as well as social environmental externality. For example, the air freight may ensure highest product quality but it can also lead to more costs and $\mathrm{CO} 2$ emission. In this sense, the real objective of the smart fresh chain should be delivering the highest product quality at the lowest possible costs (including economic, environmental and social costs).

To make the chain really smart, technologies, decision support tools, scientific and practical knowledge should be combined in use, which will be further elaborated in the following sub sections. 


\subsection{Smart Decision Support}

\subsubsection{Simulation technology}

Fresh produce supply chains are much more complex than the normal produce supply chains (Luning and Marcelis, 2006; Van Der Vorst et al., 2009). It is restricted by the perishable nature of the produce, high fluctuations in demand and prices, increasing consumer concerns for food safety (Van der Vorst and Beulens, 2002). It is also dependent on climate conditions (Salin, 1998). When uncertainties are in place, simulation technology is a powerful tool to support decision making on supply chain (re)design, building on their inherent modelling flexibility (Van Der Vorst et al., 2009). The "smart nature" of the simulation technology is that it allows the investigation and composition of the future chain scenarios without really implementing them, which avoids a lot of unnecessary costs and efforts.

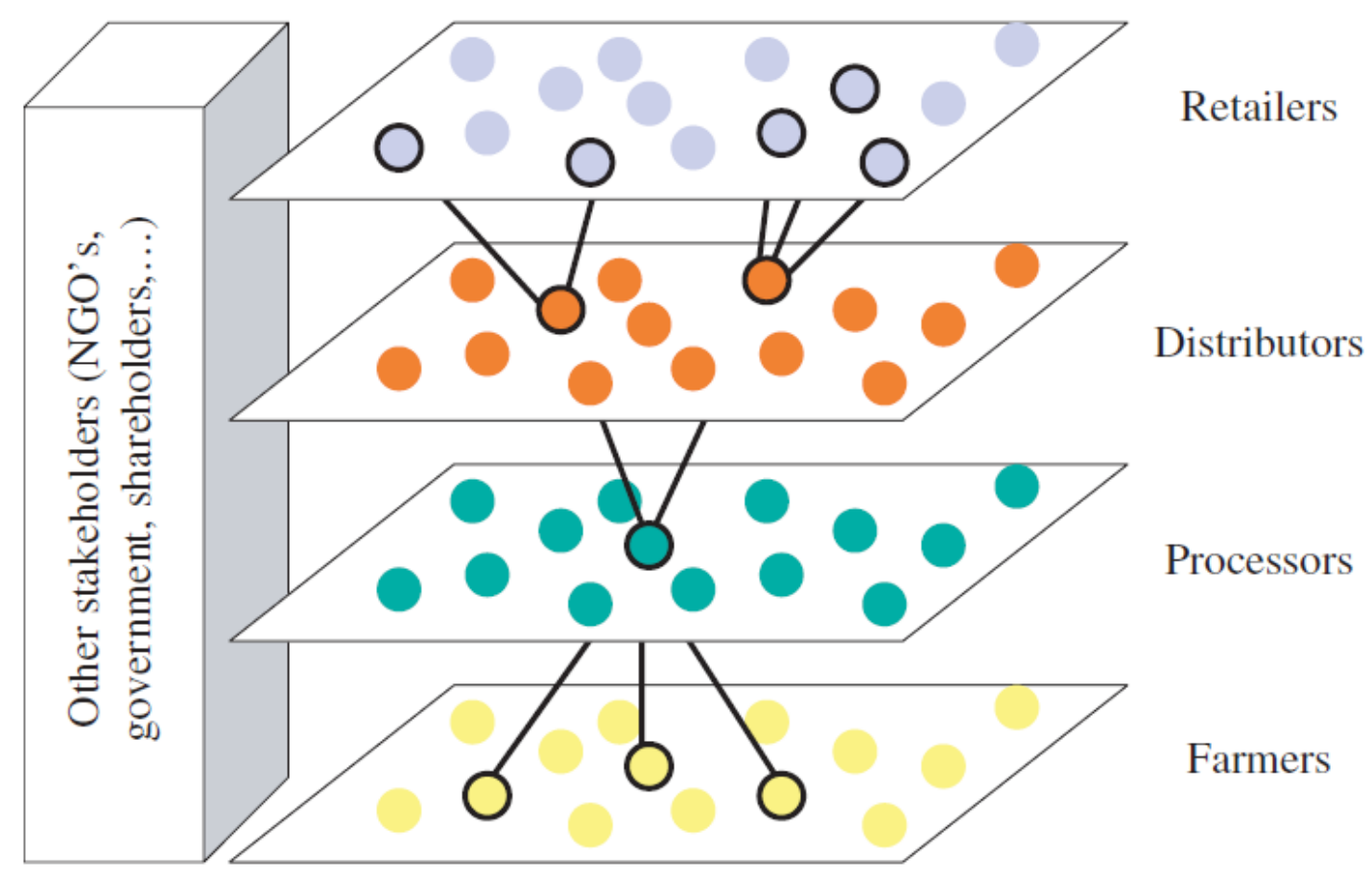

\section{Figure 25. Schematic diagram of a fresh produce (or food) supply chain network (Source: Van der Vorst et al. (2005))}

According to Van der Vorst et al. (2005), the requirements for designing a successful simulation models for a general supply chain are 1 ) clear notions of model elements and clear specified element relationships, 2) the good control of dynamic effects within the supply chain, 3) an intuitive user interface that enables the active and joint participation of the problem owner, 4) ease of modelling scenarios. For the fresh produce supply chain simulation models, additional requirements that should be fulfilled are the capacity of incorporating "quality preservation" and product heterogeneities aspects into the model (Van Der Vorst et al., 2009).

The researchers from Wageningen UR have developed a tool ALADIN ${ }^{\top M}$, a visual interactive simulation environment building on the Logistics Suite of the object oriented simulation package Enterprise Dynamics $^{T M}$ (ED) (Van Der Vorst et al., 2009). It enables the modelling of the fresh produce chain and its behaviours in a transparent manner by differentiating the physical flow and control flow (Figure 26). 


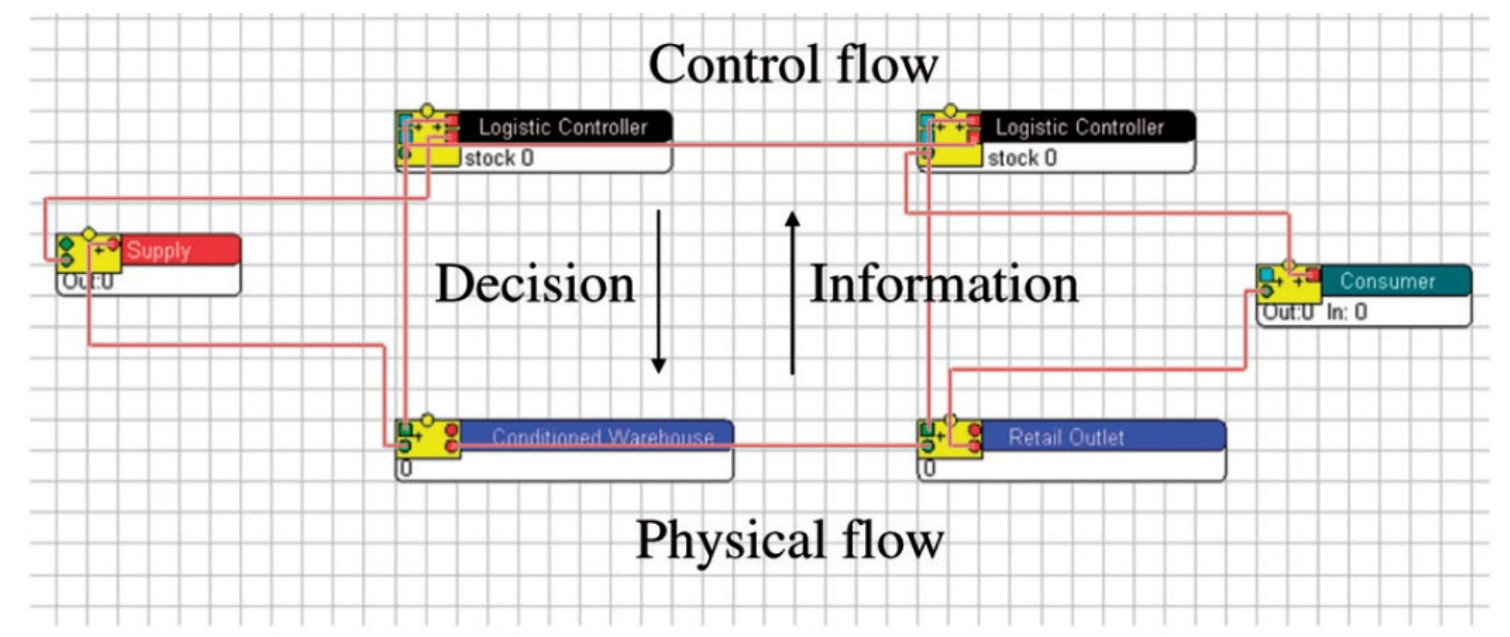

Figure 26. ALADINTM improves modelling transparency by making a distinction between the goods flow (physical flow) and its planning and control (control flow) (Source: Van Der Vorst et al. (2009))

Table 4. Specific agents in ALADINTM (Source: Van Der Vorst et al. (2009))

\begin{tabular}{|c|c|}
\hline Agents & Representation \\
\hline Production unit & $\begin{array}{l}\text { Food factory or a grower, who produces products with biological } \\
\text { variation in quality and quantity (including seasonality). }\end{array}$ \\
\hline Transportation unit & $\begin{array}{l}\text { Climate controlled truck or vessel with specific temperature and } \\
\text { modified atmosphere settings and related energy use and } \mathrm{CO}_{2} \\
\text { emission per unit. }\end{array}$ \\
\hline $\begin{array}{l}\text { Storing and distribution } \\
\text { unit }\end{array}$ & $\begin{array}{l}\text { Warehouse or retail outlet with specific climate control character- } \\
\text { istics and related energy use and } \mathrm{CO}_{2} \text { emission per unit. }\end{array}$ \\
\hline Demand unit & $\begin{array}{l}\text { Market place with demand for products with specific shelf lives, } \\
\text { colours, etc. }\end{array}$ \\
\hline Food product & $\begin{array}{l}\text { Specific food product (e.g., pepper, cut vegetable) with its specific } \\
\text { quality change model, related to the settings of environmental } \\
\text { conditions in time. }\end{array}$ \\
\hline Demand controller & $\begin{array}{l}\text { Explicit modelling of information flow and decision-making activity } \\
\text { that activate the goods flow. }\end{array}$ \\
\hline
\end{tabular}

According to Van Der Vorst et al. (2009), ALADIN ${ }^{\top M}$ has been successfully applied in many case studies where new supply chain scenarios have been evaluated. It compared alternative distribution systems (e.g., warehousing, cross docking and transport modes) for fresh product exportation including peppers and tomatoes export. Furthermore, it enables the evaluation of new ordering policies for fresh products where stock-outs and product waste (shrinkage) in retail outlets are balanced. ALADIN ${ }^{\mathrm{TM}}$ visualises and quantifies the impacts of design choices on the quality parameters such as the remaining shelf life of the product and the level of environmental load.

As aforementioned, product heterogeneity and quality decay are the specific features of the fresh produce supply chain. To realize "quality preservation" in the chain, effective quality change prediction based on monitored transport condition is the key. In the next sub section, the simulation models to facilitate quality prediction in the fresh produce chain is to be introduced.

\subsubsection{Quality change prediction model}

The intrinsic product quality refers to the initial quality of product before it enters the postharvest chain, which is highly important because of the "garbage-in-garbage-out" effects. It is not possible to ensure a high on-shelf quality if the initial quality of the product is very low even though the most advanced postharvest management is applied. In this sense, the on-shelf quality is actually determined by the combination of the intrinsic product quality and the quality losses alongside the postharvest chain. The core parameter that affects the postharvest quality losses is temperature. In a certain range, the lower the temperature, the better the preserved quality (e.g., the longer the shelf life) (See Figure 27). 


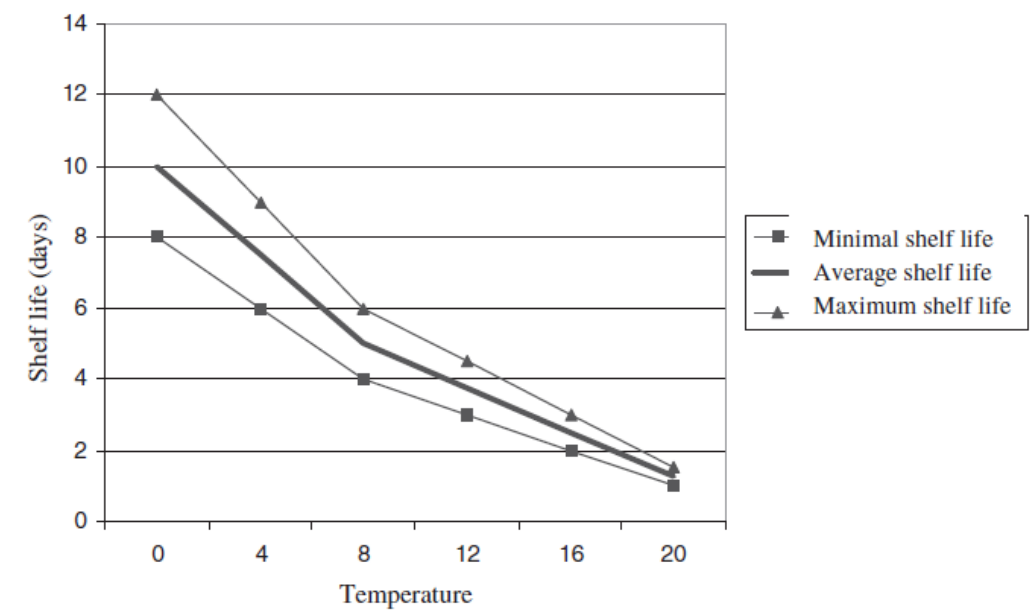

Figure 27. Average and variability in shelf life of cut pineapple depending on the temperature (Source: Van Der Vorst et al. (2009))

In addition to temperature, there are also many other factors that can affect the product quality in the fresh produce chain (e.g., mechanical damaging, pest attacking, water losses).

Now we combine quality and time in one graph (Figure 28) to derive more fruitful insights (Schripsema and Oostewechel, 2018). From the moment of harvest, the fresh product is subject to loss of quality. Therefore, the initial quality on the moment of harvest, is crucial, because quality can't be improved, it can only deteriorate. In Figure 28, one can see the quality decay of a product in an original chain (orange line).

The challenge of post-harvest quality management is to keep the quality as high as possible. Knowledge on how to do that is crucial. However, in many cases it can be observed that there is a lack of knowledge on post-harvest management.

It is important to understand that the initial quality should be a high a possible. Moreover, all kinds of technologies and treatments need to be applied to slow down the quality decay, like temperature \& humidity control, specific atmospheric treatment (like reduced oxygen), packaging etc. The blue line shows the quality decay of the supply chain with improved measurements for quality control.

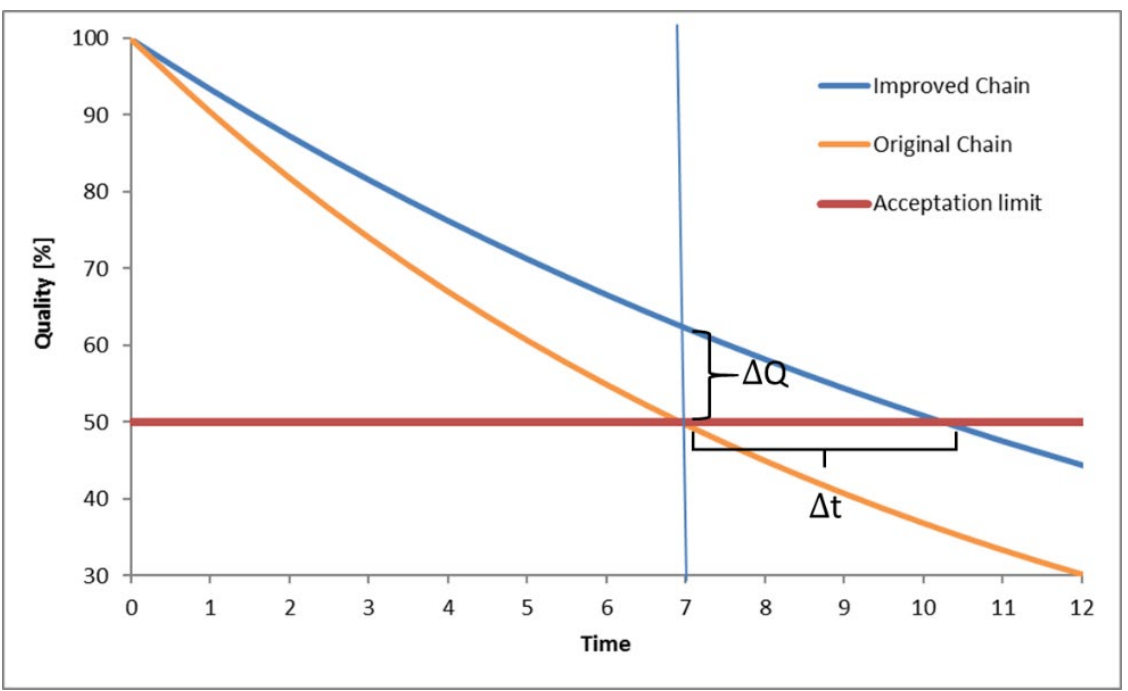

Figure 28. Example of a Quality models to show the effects of an improve chain in quality at a certain time $(\Delta Q)$ or in additional time at the same quality $(\Delta T)$ (Source: Schripsema and Oostewechel (2018)) 
To mathematically formulate the relationship described in Appendix $E$, researchers from Wageningen UR have developed the quality decay models for different products (Tromp et al., 2016; Tromp et al., 2017; Tromp et al., 2015; Tromp et al., 2012a; Tromp et al., 2012b; Tromp et al., 2012c). According to Tromp et al. (2016), the quality decay of the product can be captured by a logistic curve, where the limiting quality attribute $q$ is described as a function of time $t$ :

$q(t)=\frac{q_{\text {-inf }} q_{0} e^{k T^{t}}}{q_{\text {-inf }}+q_{0}\left(e^{k T^{t}}-1\right)}$

where $q_{0}$ is the initial value of the limiting quality attribute; $k_{T}(<0)$ represents the temperaturedependent quality-decay rate $\left(\mathrm{d}^{-1}\right)$ at storage temperature $\mathrm{T}(\mathrm{K}) . q_{\text {-inf }}$ is the upper asymptote of the logistic curve (the lower asymptote equals 0 ).

The temperature dependency of $k_{T}$ follows the Arrhenius's law:

$k_{T}=k_{\text {ref }} e^{B\left(\frac{1}{T_{\text {ref }}}-\frac{1}{T}\right)}$

where the $k_{\text {ref }}\left(\mathrm{d}^{-1}\right)$ is the quality-decay rate at a reference temperature Tref $(\mathrm{K})$. B is a productspecific parameter $(\mathrm{K})$, representing the product's temperature-sensitivity, commonly known as Ea/R. Ea represents the product's activation energy and $R$ represents the universal gas constant.

Combining the logistic curve and Arrhenius' law, the remaining shelf life $S L$ (d) after having stored the product for a storage time $t(\mathrm{~d})$ at a storage temperature $\mathrm{T}(\mathrm{K})$ can be described as:

$S L=S L_{0}-t \cdot e^{B\left(\frac{1}{T_{\mathrm{Tef}}}-\frac{1}{T}\right)}$

where $S L_{0}(\mathrm{~d})$ is the shelf life of just-processed, non-stored products, which is equal to

$$
S L_{0}=\frac{\ln \left(\frac{\left(q_{\text {-inf }}-q_{e}\right) q_{0}}{\left(q_{\text {-inf }}-q_{0}\right) q_{e}}\right)}{k_{\text {ref }}}
$$

This quality-decay model is validated using the data from the case of fresh-cut iceberg lettuce $200 \mathrm{~g}$. The results are shown in Figure 29.

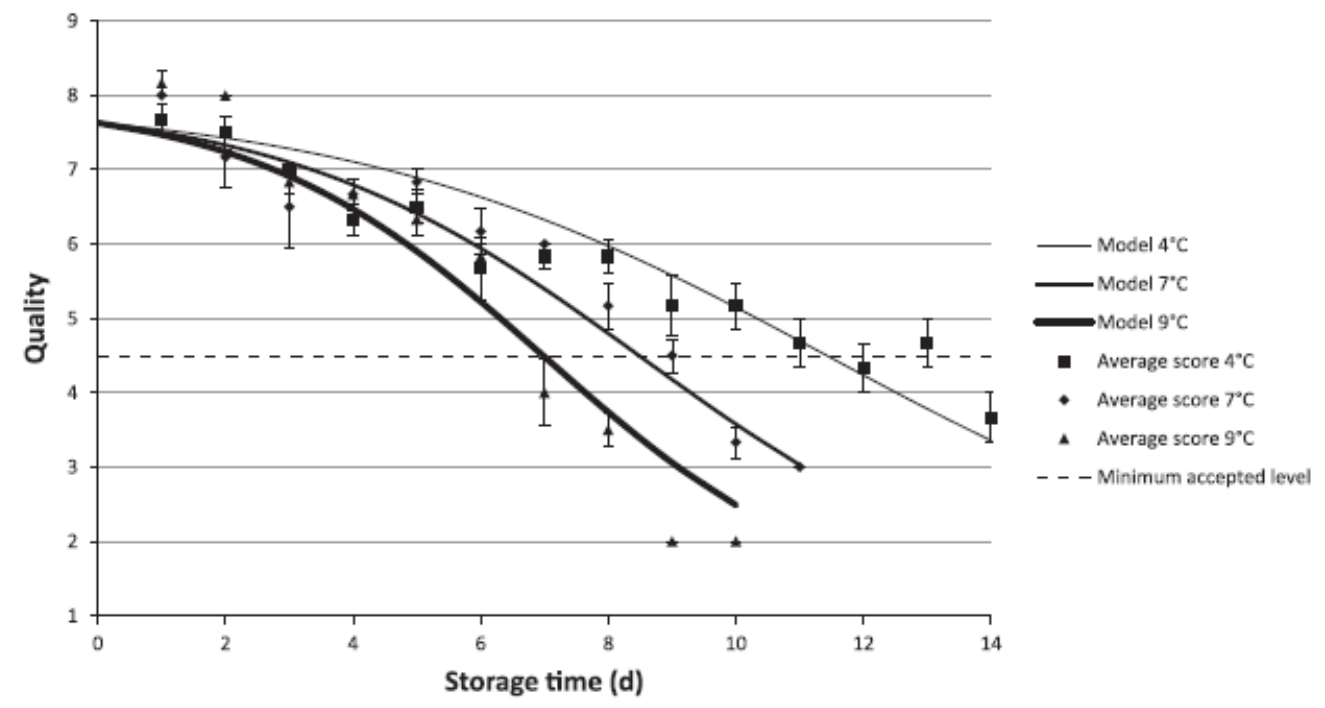

Figure 29. Quality-decay of fresh-cut iceberg lettuce $200 \mathrm{~g}$. Error bars represent standard errors of the mean (Tromp et al., 2016)

The results demonstrate a good fit of the predicted shelf life and the observed shelf life with $R_{\text {fit }}^{2}=0.92$. 


\subsubsection{Smart Fresh logistics}

Simulation technology and quality change predication model provide "science-based knowledge" to support rational decision making throughout the whole fresh produce supply chains. However, smartly implementing such knowledge in practice is even more important. To realize the ultimate goal of the smart chain, practical knowledge derived from the frontline field-work experience must be incorporated into the equation. This is because the scientific and model-based knowledge has many pre-conditions and assumptions, which inevitably simplifies the cases. The reality is often much more complex and makes science-based knowledge not directly applicable to the real-world situation, just like the laboratory results are usually difficult to be straightforward replicated outside the lab.

Smart management of fresh logistics requires the practitioners' in-depth insights in both the agroproduce sector and the general logistic sectors. It requires flexible use of the available resources and technologies catering to the specific external conditions to create the maximum values for the chain. The smartest logistic solution is not the solution embedded with the most advanced technologies but the solution that ensures the highest benefit-cost ratio. For example, in the developing countries the lack of quick pre-cooling after the harvest of the product is a major barrier that hampers the product quality. However, in the Netherlands, in a lot of situations, the pre-cooling step can be skipped by shortening the lead-time between the harvest and consumption to save costs (For example, the Dutch domestic tomato supply chains in many cases do not apply pre-cooling). This can only happen when there exist highly coordinated fresh produce chains where the farmers and retailors are seamlessly connected for order placement and fulfilment. It also requires the geographical closeness between the producing sites and the market of the products. Short chains in this sense are always preferred. That is the benefit from having the so called "Food Clusters" in the Netherlands which are established next to the big cities. Therefore, for the absence of the same pre-cooling technology, in the developing countries, especially the one with large exporting orientation, it is disastrous for product quality but in the Netherlands, it can be the great opportunity of cost-saving. This demonstrates that using advanced technologies does not necessarily mean assured favourable results. Another example is that even though one can apply the most advanced quality monitoring and predication technologies, oldfashion measures like manually checking the product quality with knifing and tasting is still very important (millions of kilos of fresh fruits have been saved by using the traditional measures according to a WUR postharvest expert). Technology-centric ideology is still very prevailing in many markets, especially in the developing countries. It is a very common phenomenon that a lot of agro food companies invest heavily in expensive equipment, infrastructures and technologies but they never use them in the correct way. At the end, such investments become burdens instead of assets. To avoid such investment mistakes, a market-driven prospective needs to be applied to select the appropriate level of investment. Namely, the investment in technologies should match the market potentials and preferences. If there is no need for a specific quality attribute in a market, then it makes no sense to invest in advanced technologies to achieve that quality attribute. In this sense, "smart chain" has more to do with "smart use of technologies and resources as well as smart investment level selection" than merely with "smart technologies" themselves. This fact points out the direction that the modern fresh logistics management should go.

There is a new fresh logistics management concept called Quality Controlled Logistics (QCL) (van der Vorst et al., 2014) which to a large extent caters to the smart chain requirements. QCL refers to dynamically planning, implementing, and controlling the efficient, effective flow and storage of food products, services and related information between point of origin and point of consumption (van der Vorst et al., 2014). It is a market driven approach which aims to deliver the products that satisfy consumer preferences within the acceptance period of product quality attributes (van der Vorst et al., 2014). It makes use of variation in product quality, developments in technology, heterogeneous needs of customers and the possibilities to manage product quality development in the distribution chain (van der Vorst et al., 2014). There are six elements associated with QCL which are presented in Table 5 together with their operational requirements. 
Table 5. QCL elements and their operational requirements (Source: van der Vorst et al.

\begin{tabular}{|c|c|}
\hline QCL-elements & Operational requirements \\
\hline $\begin{array}{l}\text { 1. Consumer } \\
\text { preferences \& product }\end{array}$ & $\begin{array}{l}\text { - Understand consumer preferences of quality attributes } \\
\text { - Get insight in product acceptance period for all market segments }\end{array}$ \\
\hline $\begin{array}{l}\text { 2. Critical quality } \\
\text { points (CQP) for quality }\end{array}$ & $\begin{array}{l}\text { - Get insight in dynamic behaviour of product quality attributes } \\
\text { - Systematic assessment of CQPS that have major impact on } \\
\text { product quality \& availability in retail outlets }\end{array}$ \\
\hline $\begin{array}{l}\text { 3. Product quality } \\
\text { measurement and }\end{array}$ & $\begin{array}{l}\text { - Have ability to measure \& analyse quality at CQPs } \\
\text { - Have automated quality measuring at CQP's } \\
\text { - Have prediction models to calculate real product quality }\end{array}$ \\
\hline $\begin{array}{l}\text { 4. Data logging and } \\
\text { exchange of }\end{array}$ & $\begin{array}{l}\text { - Use advanced data loggers and techniques (RFID ,GPS) to capture } \\
\text { relevant information real-time \& reliable } \\
\text { - Exchange quality, supply and demand information in chain }\end{array}$ \\
\hline $\begin{array}{l}\text { 5. Local dynamic/ } \\
\text { adaptive logistics and } \\
\text { quality control }\end{array}$ & $\begin{array}{l}\text { - Set local targets for quality attributes, reduce variability inter- } \\
\text { nally and manipulate product quality in line with market demands } \\
\text { - Apply quality driven inventory management principles } \\
\text { - Sort for homogeneous small batches, have quality based order } \\
\text { picking and transport (matching delivery with consumer wishes). }\end{array}$ \\
\hline $\begin{array}{l}\text { 6. AgriFood Supply } \\
\text { Chain Management }\end{array}$ & $\begin{array}{l}\text { - Establish full chain collaboration to create demand-driven chains } \\
\text { - Direct goods to highest value markets and apply efficient } \\
\text { replenishment and JIT principles for responsive distribution } \\
\text { - Use temp. controlled reefer containers and packaging with MA }\end{array}$ \\
\hline
\end{tabular}

Compared to the traditional logistics approach, QCL is different in several aspects (See Appendix I). In short QCL applies quality-centric strategy and focuses on the quality improvement according to consumer preferences by optimally using supply chain data and dynamically making the logistics plans. The QCL can therefore be considered as the "smart chain" fresh logistics.

\subsubsection{Big data and postharvest technologies}

Big data as the next generation technology will revolutionize the global food supply chain (Magnin, 2016). It can help increase supply chain transparency, improve operations efficiency and reduce food waste (Magnin, 2016). There are many examples showing that big data have been playing an increasingly important role in postharvest management.

\section{Intelligent packaging}

Big data have been applied in monitoring food safety and quality. For example, the intelligent packaging made of a small gas sensor (one kind of chemical sensors) combined with the RFID technology is used to monitor and maintain quality and safety of food in transport and storage (Matindoust et al., 2016). The small gas sensor is tailored to the type of food packaging and a communication device is used to transmit alarm message to the consumer; the intelligent packaging enables the interaction among the product, the package and the environment (Matindoust et al., 2016).

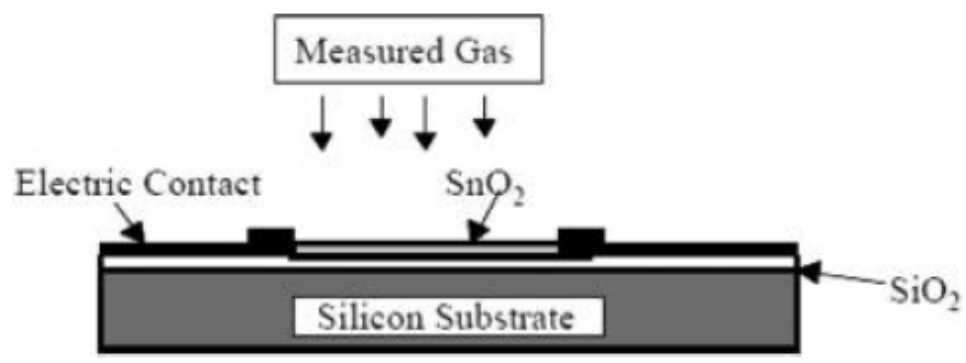

Figure 30. Gas sensor (Matindoust et al., 2016) 


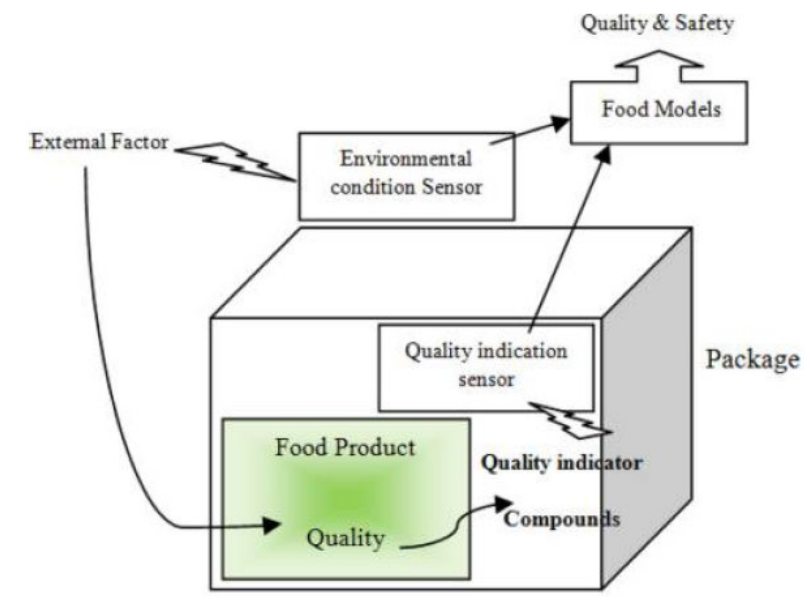

Figure 31. Schematic illustration of Intelligent Packaging with sensors that monitor environmental conditions, or quality attributes of the product related with overall food quality change (Heising, 2014)

\section{Bayesian networks analytics}

Agricultural production chains have a sequence of processes, e.g., planting/growing, harvesting, sorting/grading, post-harvest treatment, packing, and exporting (Holt et al., 2018). The change of the happening probability of a former process will alter the happening probabilities of the following processes. This provides the basis to apply Bayesian networks for future prediction which enables to compare the effectiveness of different interventions in the fresh produce chain. For example, the Bayesian networks were used to compare pest control interventions on commodities along agricultural production chains, which allows the varying effect and uncertainty of factors affecting pest infestation to be incorporated in the analysis (Holt et al., 2018). An example of using Bayesian network to investigate the pest infestation on a production chain is demonstrated in Appendix $F$.

\section{Blockchain}

In recent years, Blockchain has become a very hot topic all over the world and numerous companies have been engaged in Blockchain application development (Ge et al., 2017). Block chain is in fact a cryptographic technology which was first used to create the Bitcoin. The pivotal feature of the Block chain is the so-called feature of "decentralization". Through the continuous and transparent updating of trade records in an internet network, the trade histories will be stored in all the individual computers of the network based on the pre-agreed protocol (the more computers in the network, the more trustworthy the associated block chain). This solves the problem of information asymmetry and misuse. It therefore does rely on the "trust" provided by the third party with authority to perform transactions. The decentralization can save huge costs used to obtain the third-party trust.

It is believed that combining Big data and Blockchain can realize a new level of analytics (a match made in heaven) because 1) Blockchain-generated Big Data cannot be forged due to the network architecture and 2) Blockchain-based Big Data is structured, abundant and complete, making it a perfect source for further analysis (Fedak, 2018).

Many researchers believe the application of Block chain has a great potentials in improving the agro product chain (e.g., tracking the provenance of the product, issuing, validating and auditing certificates) because increased number of food scandals has been observed (e.g., the Italian organic food scandal in 2011 and the horsemeat scandal in 2013) which hamper the trust factor in the agro food chains (Ge et al., 2017).

The Blockchain technology can bring in many opportunities and challenges for the stakeholders in the agro-product sector (Appendix G).

\section{Cold chain}

Big data will play a big role in shaping the future cold chain especially with the technologies like internet of things (IoT) to ensure real-time asset management, improved customer service and relationships, accurate forecasting and inventory as well as connected stakeholders and networks 
(Anonymous, 2018). The development of the wireless sensor networks help to generate a lot of "big data" across the cold chain for trace \& track, food safety and security and risk management issues (Chaudhuri et al., 2016). Those high-volume, high-velocity, and high-variety sets of dynamic data requires advanced big data analytic approaches to valorise their values, which is far beyond the capacity of the traditional data analytical methods (Chen and Zhang, 2014). To cater to the new requirements, Chaudhuri et al. (2016) invent a framework to guide 'big data' development and implementation in cold chain logistics (See Appendix $\mathrm{H}$ ).

\subsection{Smart chain application in real cases}

In this section three cases of "smart chain" applications are introduced, each of which is corresponding to one fresh produce category (i.e., vegetable, fruit or flower).

\subsubsection{Pineapple Case}

The pineapple case is based on the work of Van Der Vorst et al. (2009) where the simulation-based study incorporating quality predication modelling is conducted for the pineapple import from Ghana to the Netherlands. Compared to the intact pineapple which can be kept for several weeks, the keepability of the cut pineapple is much more restricted. Currently, a large amount of pineapples is transported to the Netherlands by the costly air mode because the alternatives such as traditional sea transport has led to significant quality decay problems due to the long transportation time. Motivated by such an observation, Van Der Vorst et al. (2009) perform the simulation research to quantitatively compare two scenarios of pineapple transportation. The first scenario is concerning the air transport of the sliced pineapple while the second scenario considers the sea transport of the whole pineapples

(Figure 32).
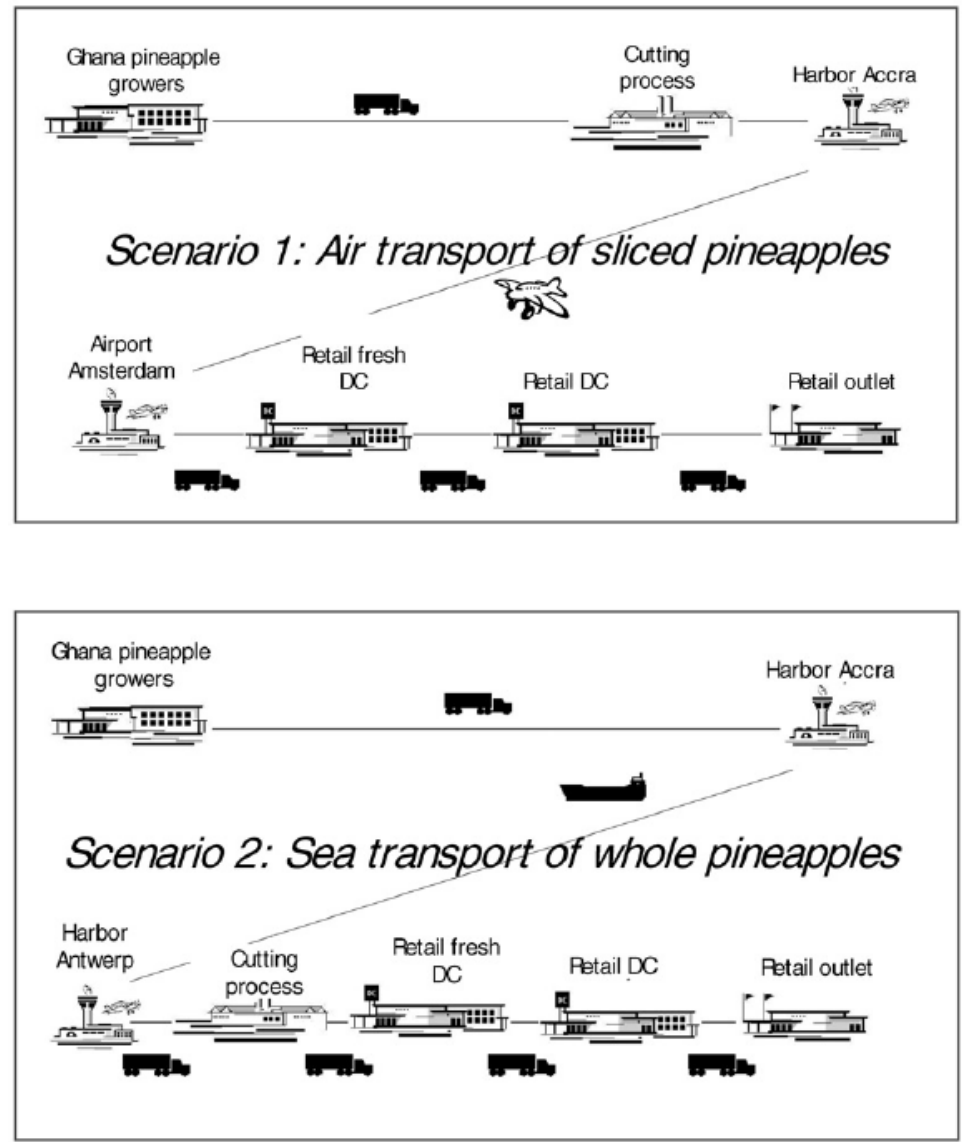

Figure 32. Two supply chain scenarios for importing pineapples from Ghana Tomato Case (Source: Van Der Vorst et al. (2009)) 
In order to predict the quality change during the transportation, a generic quality decay model was developed by Wageningen Researchers and validated by the field experts. The simulation results are demonstrated in (Table 6).

Table 6. Comparing the overall results of the two scenarios (Source: Van Der Vorst et al. (2009))

\begin{tabular}{lccc}
\hline Scenario & Average quality & Logistics costs & Energy and emission \\
\hline Air chain Ghana & + & - & -- \\
& (BBD 3.9 days; & $(1192$ euro/wk $)$ & $(77,227 \mathrm{MJ} / \mathrm{wk}$ \\
Sea chain Ghana & $+/-$ & + & $5638 \mathrm{~kg} \mathrm{CO} 2)$ \\
& bad before BBD 5.9\% & + & + \\
& bBD 3.7 days; & $(793$ euro/wk) & $(14,508 \mathrm{MJ} / \mathrm{wk}$ \\
& bad before BBD 10.6\%) & & $1059 \mathrm{~kg} \mathrm{CO} 2)$ \\
\hline
\end{tabular}

From Table 6 we can see that compared to the sea-mode scenario, the air-mode scenario can ensure a slightly better BBD (Best-Before-Date, a parameter to indicate the quality of the food instead of safety of the food) by 0.2 day. It at the same time reduces the percentage of bad before BBD (i.e., the percentage of all products having a keepability which is less than the BBD-code indicates) from $10.6 \%$ to $5.9 \%$. On the other hand, the sea-mode scenario is superior in terms of relatively lower logistics costs and significantly lower energy use and $\mathrm{CO} 2$ emission. Such information provides the basis for the decision makers to balance the trade-offs between different fresh produce chain designs and make the scientifically sound decisions. For example, since the expected cost, energy and emission gains seem to outweigh the quality losses, it is at least worthwhile to consider switching part of air-based cut pineapple transport to the sea-based whole pineapple transport. What is more attractive is that the derivation of such insights does not rely on conducting long-term and expensive real-life pilot projects, which saves a lot of time and costs.

\subsubsection{Tomato case}

The tomato case is based on the work of van der Vorst et al. (2014) which demonstrates how to use the QCL concept to identify the improvement opportunities in the fresh produce supply chain. The typical tomato supply chain in the Netherlands is shown in Figure 33:

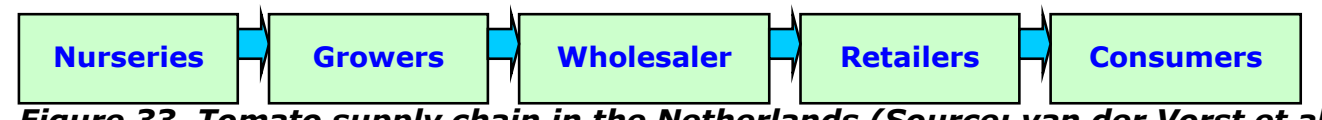

Figure 33. Tomato supply chain in the Netherlands (Source: van der Vorst et al. (2014))

The nurseries provide young plants to the growers. Growers deliver tomatoes to the wholesalers or directly to the retailers. The lead-time between the harvesting of the tomatoes and positioning the tomatoes on shelf is between 2 to 10 days. There are significant variances for the colour, taste, firmness of the tomatoes due to the biological variety between and within the cultivars.

Schouten et al. (2010) determined the quality attributes colour and firmness that consumer would like to buy for direct consumption or consumption within several days. By using QLC analysis, a list of improvement opportunities has been identified and presented in Table 7. 
Table 7. Overview of identified improvement opportunities in a real life tomato supply chain (Source: (van der Vorst et al., 2014))

\begin{tabular}{|c|c|}
\hline QCL element & Improvement opportunity in the chain \\
\hline $\begin{array}{l}\text { 1. Consumer } \\
\text { preferences \& } \\
\text { Acceptance periods } \\
(\text { APs) }\end{array}$ & $\begin{array}{l}\text { - Different market segments and its customer requirements should be } \\
\text { identified. Next, the APs for these specific markets should be } \\
\text { determined. }\end{array}$ \\
\hline $\begin{array}{l}\text { 2. Critical quality points } \\
\text { (CQP) }\end{array}$ & $\begin{array}{l}\text { - More insight should be gathered on the CQPs. } \\
\text { Transport conditions such as temperature need to be set. This setting } \\
\text { depends again on the travel/ storage time and how far the products } \\
\text { need to be developed at the retailer. }\end{array}$ \\
\hline $\begin{array}{l}\text { 3. Product quality } \\
\text { measurement and } \\
\text { prediction }\end{array}$ & $\begin{array}{l}\text { - Different quality classes are defined with help of procedures and } \\
\text { standards, such as colour scale card for manual grading. Batches should } \\
\text { get their own ID code showing quality score. } \\
\text { As the product arrives at wholesaler site, there should be advanced } \\
\text { measurements of products quality. } \\
\text { Regular monitoring should take place to adjust product offerings related } \\
\text { to APs. } \\
\text { Predictive models of product quality at the grower should be used to } \\
\text { support the decision to harvest products at a certain stage and time. }\end{array}$ \\
\hline $\begin{array}{l}\text { 4. Data logging and } \\
\text { exchange of information }\end{array}$ & $\begin{array}{l}\text { Detailed information on quality status of cargo and environmental } \\
\text { conditions should be registered and communicated to chain partners } \\
\text { using information standards and data loggers. Then all chain partners } \\
\text { know now the origin, quality level, the storage and travel conditions of } \\
\text { that particular batch including the quality development. } \\
\text { Retailers should predict demand and pass this information to other } \\
\text { chain actors enabling responsive demand driven logistics. }\end{array}$ \\
\hline $\begin{array}{l}\text { 5. Local dynamic/ } \\
\text { adaptive logistics and } \\
\text { quality control }\end{array}$ & $\begin{array}{l}\text { - Products should be harvested in uniform stage of maturity for specific } \\
\text { market segments. If there is variation in the harvested fruits, sorting } \\
\text { and grading on products should result in classified batches based on } \\
\text { their quality level. } \\
\text { With the help of the different quality classes harvested, a } \\
\text { planning/prediction can be made about how fast the product needs to } \\
\text { go from the grower to wholesaler and also the conditions (such as } \\
\text { temperature) needed to maintain or change the quality. } \\
\text { Inventories should be managed and allocated to customers based on } \\
\text { quality category. }\end{array}$ \\
\hline $\begin{array}{l}\text { 6. AgriFood Supply } \\
\text { Chain Management }\end{array}$ & $\begin{array}{l}\text { - With support of information about APs and real product quality (using } \\
\text { predictive models), the environmental conditions needed should be } \\
\text { adjusted in the chain according to wished final development/maturity } \\
\text { stage of fruit at arrival. } \\
\text { Quality levels of product batches and their related AP should be } \\
\text { considered when applying SCM practices in order to deliver the right } \\
\text { amount of product at right place at right time with the right quality. } \\
\text { The products must be in the right stage of development and } \\
\text { maintained at appropriate temperature to be able to present within the } \\
\text { acceptance period by the time they arrive at retailers. }\end{array}$ \\
\hline
\end{tabular}

The six QLC elements are addressed one by one from different angles. Through such analyses, we break down the supply chains into manageable units and explore critical areas for improvement. It operationalizes the abstract supply chain concepts into the actionable points and therefore improves the practicability of the fresh produce supply chain management.

\subsubsection{Cut rose case}

The cut rose case refers to the work of Harkema et al. (2017). Roses are primarily cultivated in Colombia, Ecuador, Kenya, Netherlands and mainly sold to consumers located in other regions of the world (Europe, North America, Japan). During last years, long-distance transport of cut flowers by sea has become a serious way of transport (Figure 34). 


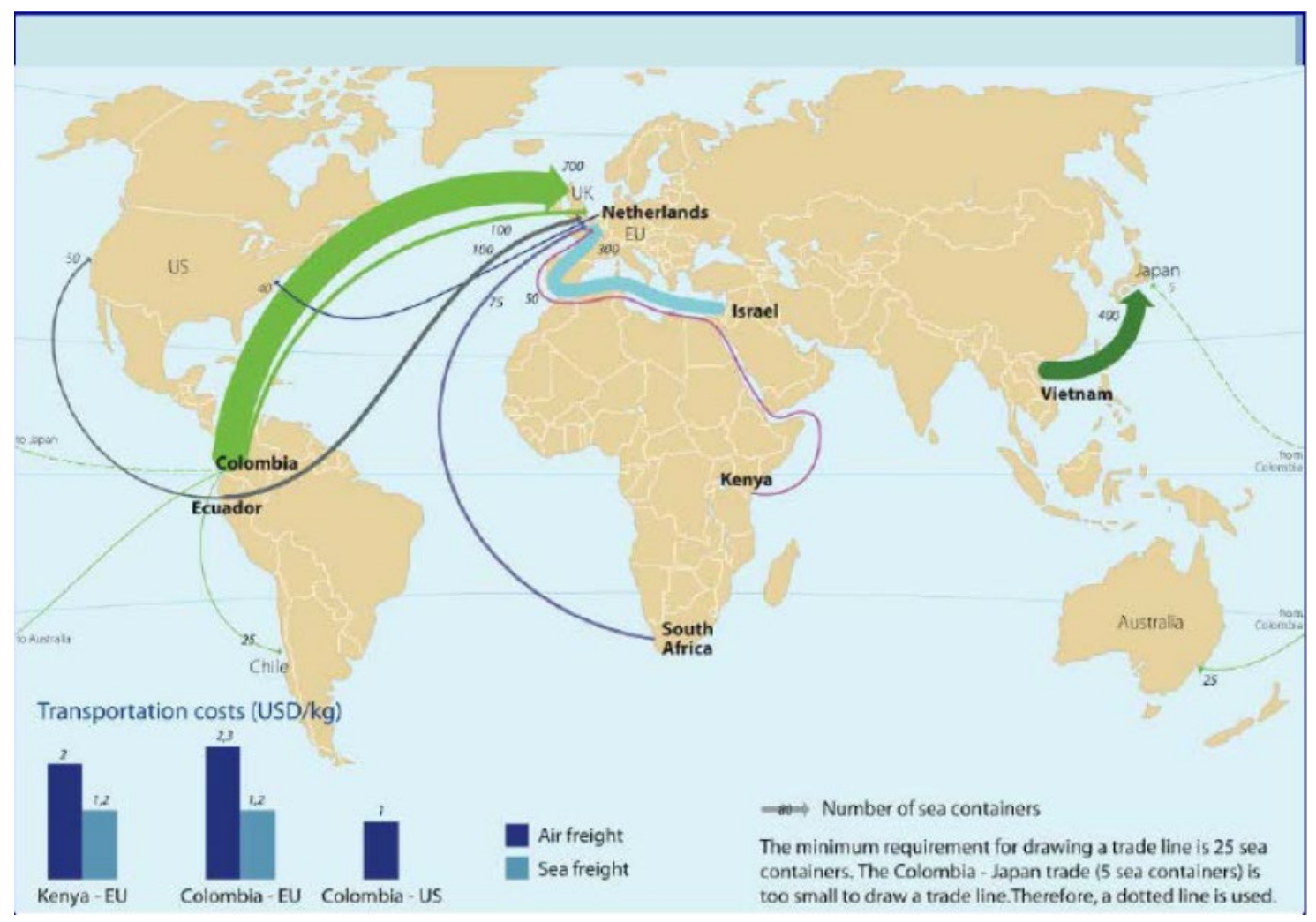

Figure 34. Global map illustrating global trade lines of cut flowers transported by reefer containers in 2013 (Source: FloraHolland, 2014)

Figure 35 shows an example of rose supply chain with sea freight from grower to shop. The roses are harvested, sorted, packed at the grower, transported to a consolidation centre, placed in a reefer container, transported to the harbour, shipped and transported to an auction/distribution centre and further transported to the shop and supermarkets.

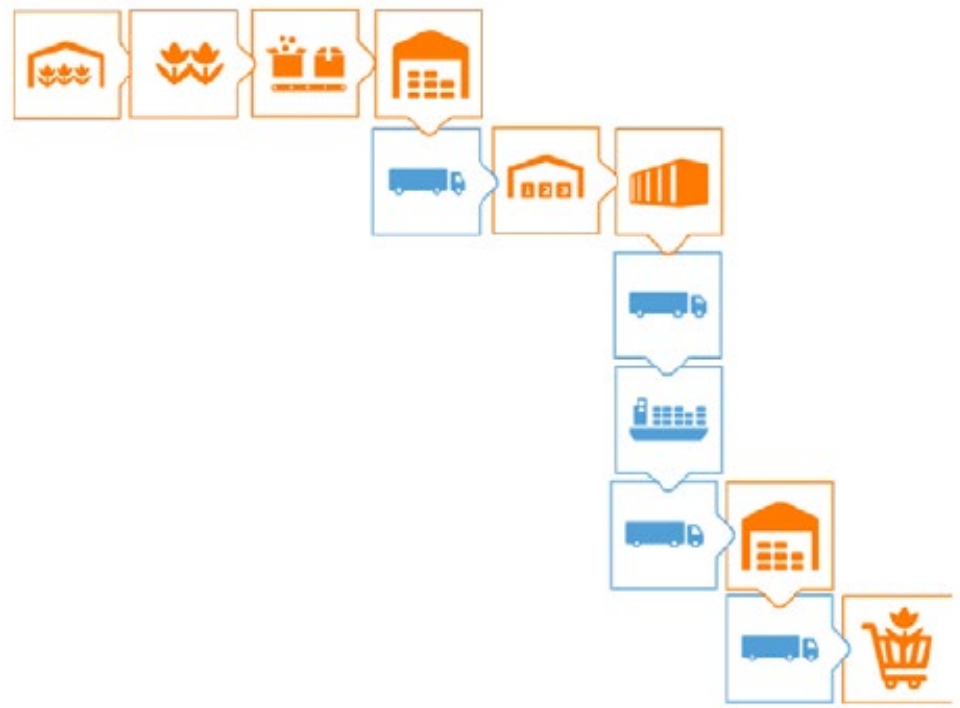

Figure 35. Example of a rose supply chain with sea freight from grower to shop (Source: Harkema et al. (2017))

Given such a background, Wageningen Food \& Biobased Research has conducted research in the past ten years to investigate 1 ) the possibility of storing and transporting cut roses several weeks with acceptable quality (vase life) and 2) the ways to achieve that. The combination of pilots and research experiments have shown it is possible to realize that with good cultivar selection, good growing conditions and good postharvest technology applications (e.g. better temperature control in reefer container, better quality predication module). 
The formal conclusions from the researchers are that storage or transport of cut roses in reefer containers up to 4 weeks is possible if all actors in the chain comply with the guidelines and recommendations. This is a very encouraging finding because it can significantly reduce transportation costs and greenhouse gas emissions compared to the traditional air-borne transportation.

\subsection{Potential smart chain applications in South Korea}

South Korea is one of the most developed countries in Asia has many similarities to the Netherlands, e.g., having the favourable geographical location, having the major port, having high-tech industry.

For example, the Netherlands is located in the central location of western Europe and has the Rotterdam port (the $12^{\text {th }}$ largest port in the world) as the regional logistic/fresh hub.

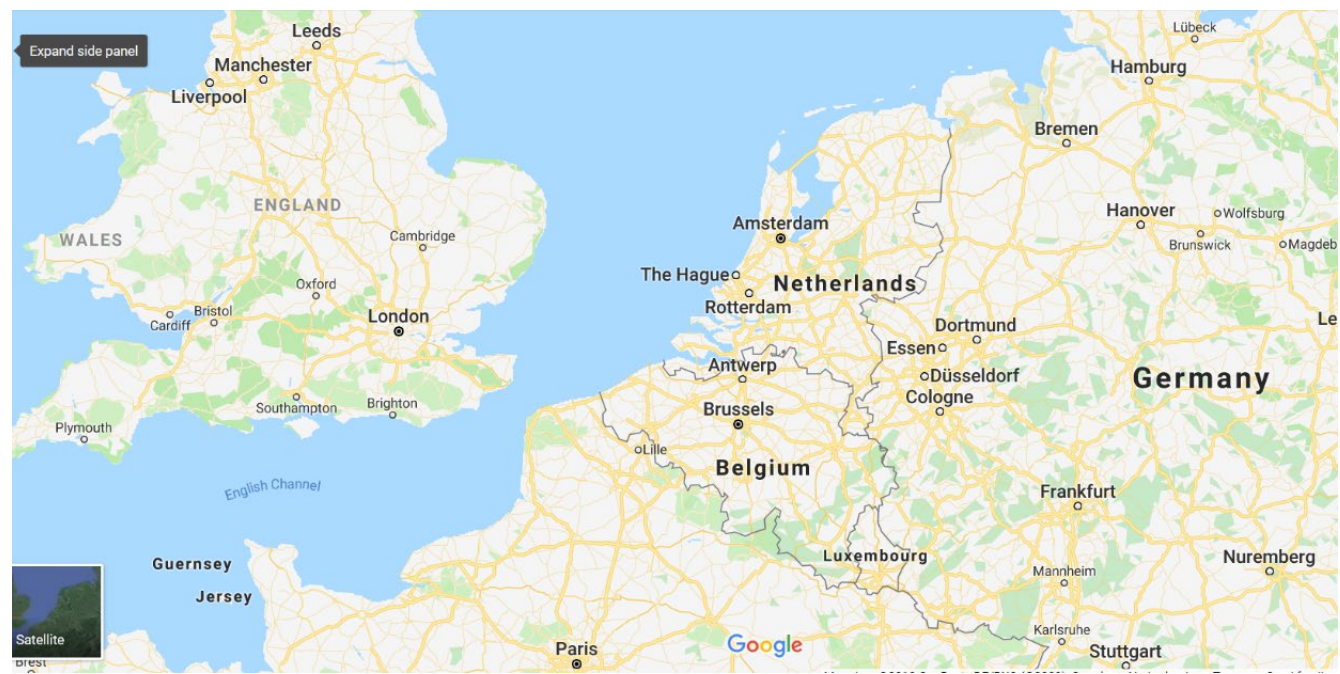

Figure 36. The region surrounding the Rotterdam port (Source: Google map)

Figure 36 shows that Rotterdam port sits in the centre of western Europe, close to the United Kingdom, Germany and France, the three major markets in that region with 150 million high-income consumers.

Similarly, South Korea is located in the middle between Japan and China with the world fifth largest port i.e., Busan port (Figure 37). 


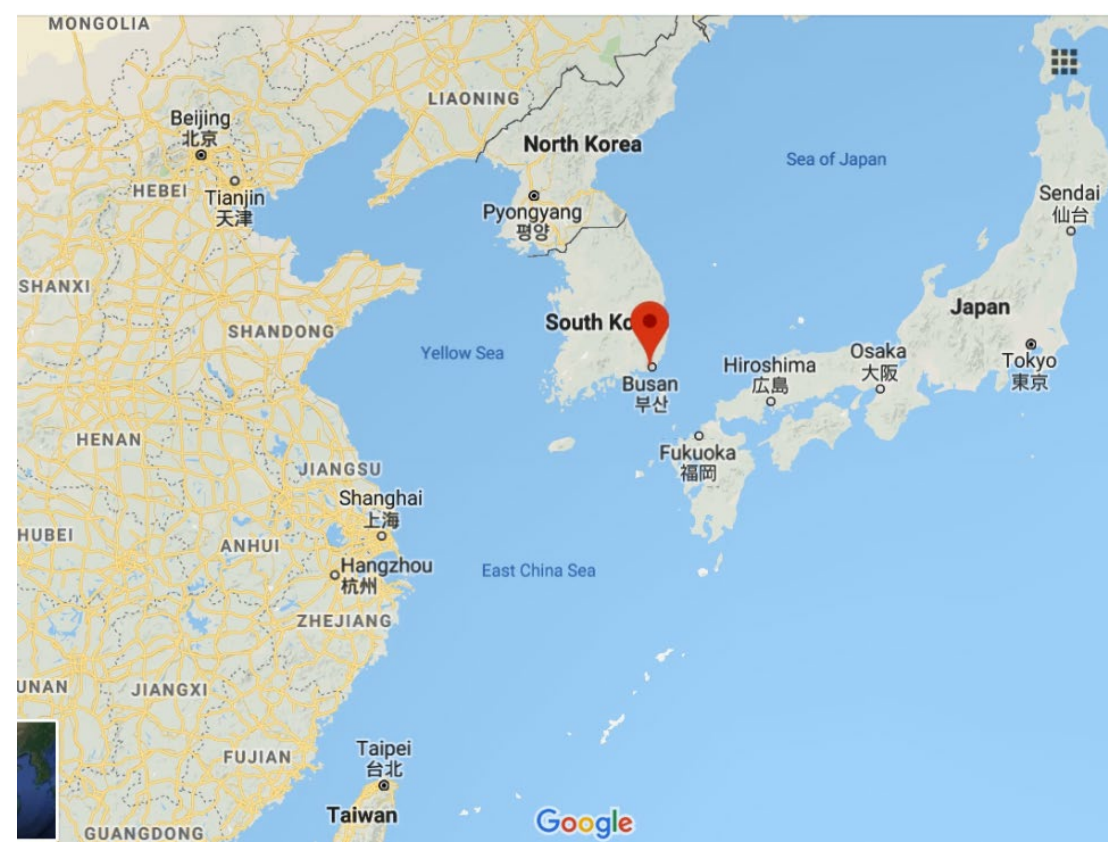

Figure 37. The region surrounding the Busan port (Source: Google map)

In this region, Japan and South Korea have 180 million high-income consumers and China as the world second largest economy has 1.3 billion consumers. In this sense, South Korea also has the favourable geographical condition to become the regional fresh hub which absorbs the fresh goods flows in this region.

The same as there are competing ports (e.g., port of Antwerp, port of Hamburg) to the port of Rotterdam, there are also ports competing with the Busan port to become the regional fresh hub. Japan does not have comparable ports of the same size to Busan port and therefore not the major competitor. China has many big ports such as Shanghai port (the largest port in the world) in this region. Compared to China and China's big ports, South Korea and Busan port have comparative advantages. Firstly, Busan port is much closer to the centre of gravity of the China, South Korea and Japan markets, which is most attractive for building the central fresh hub from a logistics point of view. Secondly, South Korea is the high-tech country that can facilitate the build-up of better coordinating and efficient fresh supply chains. For example, the Busan port can have a higher productivity than China's ports because of high technology application and provides the competing edge for South Korea. Moreover, South Korea has the leading position in the semi-conductor industry (e.g. Samsung) which is the basis for developing the next generation IT application such as internet of things. Applying the next generation IT in logistics will substantially improve the transparency and agility of the fresh produce chains, which gives South Korea another edge towards China. Thirdly, the cold chain infrastructure in China is quite lagging behind which is fatal for the fresh hub development. In the future, South Korea can invest more in cold chain facilities especially in the Busan area to further strengthen its comparative advantage to China.

One difference between the Dutch and South Korea situations is that for the goods unloaded in the Rotterdam port, road shipments are available for the remaining part of the transportation even to the United Kingdom. For the moment, goods transportation from South Korea to Japan and China still relies heavily on sea freights, which is not in favour of short go-to-market lead time. However, in the future, after the South Korea-Japan undersea tunnel and South Korea-China undersea tunnel/Ferry projects are completed (currently being under evaluation), fast road transportation of fresh products between the three countries will become the reality. Especially as the demands for the development of China Japan ROK FTA grow, those mega projects to connect the three countries can be accelerated.

After South Korea and Busan port become the logistics/fresh hub in the region. The aforementioned (postharvest) technologies in previous chapters can be applied to create significant values. For example, South Korea can learn Dutch dynamic temperature control technology in the reefer containers to reduce energy use, which is most interesting when the shipment volumes are large. 
It is necessary to point out that the above analysis is based on general considerations. To really prove its validity, more in-depth feasibility studies are required to build up the confidence. 


\section{Future challenges}

In the future, the global fresh produce chains face many challenges from different angles. On the supply end, the fast-growing world population combined with the rapid degradation of nature resources impose increasing pressure on postharvest loss prevention throughout the whole fresh produce supply chains. The losses of harvested fresh products in storage or transportation mean all the inputs (e.g., energy, fertilizer, finance, water) in pre-harvest stages are wasted. Given the big amount of postharvest losses for fresh produces, we could even say it is not that we cannot produce enough food to feed the world population but that we cannot smartly use the postharvest technologies to prevent the food wastes/losses. Even though we are able to save a small portion of the total postharvest losses, it will already release a lot of pressure for the nature resources and contribute significantly to global sustainability. Moreover, with the further globalization of the food chains, the sourcing of the fresh products will become even more sophisticated in the future. A hybrid supply network with both local and international product sourcing needs to be efficiently organized, which is a hard task for the supply chain practitioners to manage.

On the consumer end, more and more attentions are shifted from the traditional cost focus to the safety and quality focus. The increased food-safety concern requires more transparency in the food supply chains. Such a requirement puts the trace $\&$ track capability including its reliability level in the centre of the equation. Good traceability on the box level is already quite complex and the future attempts should aim to ensure the traceability on the individual fruit level which is far more complicated to realize. The quality on the one hand refers to the biological quality of the products (e.g. colour, firmness, sugar content). Future consumers would like to buy the ready-to-eat products which has the best combination of colour, firmness, sugar, acids etc. To realize one of the quality attributes is relatively easy but to have all the biological attributes combinatorically best at the right moment is extremely difficult. What makes it even more difficult is that in addition to the biological quality, consumers pay more and more attentions to other dimensions of the product quality, e.g.,

sustainability, animal welfare, which further restricts decision space for decision makers to find out the optimal solution. Moreover, as the development of e-commerce, the problem associated with the lastmile fresh produce delivery becomes a bigger and bigger problem. The e-order quantities are usually very small but the speed (from order to delivery) requirement is very high. Together with severe food integrity concern, the last-mile delivery of the fresh products is expected to be the most expensive part of the whole logistic process with a lot of other social, environmental implications (e.g., traffic congestions, $\mathrm{CO} 2$ emissions, etc.)

In Asian countries e-commerce is really crucial, but many suffer from logistic costs. Although the consumer service level quite well, reduction of costs and efficiency of the back-office management are necessary. South Korea might be a front runner in this development based on smart IT solutions.

From the technological perspective, it is also very challenging to harmonize the new technologies with the traditional logistics system. For example, the blockchain technology based on the philosophy of decentralization is totally different from the traditional ICT approaches applied in fresh produce logistics. Applying blockchain could mean the total renovation or even abolishment of the existing ICT infrastructure, which means the previous investment will go vain. This could hamper the motivations of the industry players to adopt the blockchain technology. Therefore, finding the solutions to harmonize emerging technologies with the existing system is a crucial point to be addressed.

Specific to the Netherlands, the major challenge for it is to maintain its leading position in the global fresh produce market. There are more and more competing countries within and outside Europe starting to challenge the Netherlands' market position. For example, even for the most advanced Dutch flower sector, its leading position is challenged by the countries like Columbia reflected by the gradually declining of the market shares for the Netherlands. To keep the comparative advantages in the long term, the Netherlands needs to invest more in agricultural technologies and management skill building. 


\section{Discussion and conclusion}

Netherlands is a small country that stands in the frontline of the world agriculture. It is the second largest food exporter in the world and has a prominent leading position in the global agricultural product market. The Dutch agricultural sector is featured by its high tech and high productivity. The Netherlands invested heavily in high tech such as advanced breeding, agricultural mechanization/automation but it also develops innovative postharvest technologies to better store and transport the fresh products. It also applies the "smart chain" approach to build up the more efficient and better coordinated fresh produce supply chains.

To reflect on the successful Dutch experience and introduce it to outsiders, in this report, we devoted efforts in elaborating the postharvest technologies and "smart fresh produce supply chains" following the typical "hardware" and "software" framework used by Wageningen Food \& Biobased Research (WFBR). We first introduced some general trends and issues related to the postharvest technologies and management. Then we described some major postharvest R\&D projects conducted by WFBR. Afterwards, we described the concept of "smart chain" and introduce some smart decision support approaches e.g., simulation technologies, big data, blockchain. Followed by that, three successful cases with "smart chain" applications were presented. After that, based on the specific situation of South Korea, we on the high level indicated the favourable conditions South Korea have to become the fresh hub in the eastern Asian region based on which "smart chain" approaches can be applied to consolidate South Korea position. Finally, we describe the future challenges faced by the global and Dutch fresh produce supply chains.

Through the whole report we would like to convey a central message (which is also the conclusion of the report) that technologies cannot solve the problems by themselves; they need to be used in the appropriate way combined with many other factors to really function. In others words, smart chains do not mean the simple piling of smart/advanced technologies (hardware) but mean the smart use of available technologies and resources and the smart selection of the proper investment level according to market demands (software). Only when the hardware is smartly combined with the software, the "smart fresh produce chain" with better efficiency and coordination can be established. 


\section{Reference}

Anonymous, 2018. How IoT is shaping big data to transform the cold chain. Controlant https://controlant.com/blog/2018/how-iot-is-shaping-big-data-to-transform-the-cold-chain/.

Aulakh, J., Regmi, A., Fulton, J., Alexander, C., 2013. Food losses: Developing a consistent global estimation framework, Agricultural and applied economics association annual meeting, August, pp. 4-6. Boon, J.K., 2015. Netherlands world's biggest (re-)exporter for 11 fruit \& veg products. FreshPlaza http://www.freshplaza.com/article/135083/Netherlands-worlds-biggest-(re-)exporter-for-11-fruit-and-vegproducts.

CBS, 2018. Dutch agricultural exports at record high. https://www.cbs.nl/en-gb/news/2018/03/dutchagricultural-exports-at-record-high.

Chaudhuri, A., Dukovska-Popovska, I., Chan, H.K., Pawar, K.S., 2016. Development of a framework for big data analytics in cold chain logistics, Internatioal Symposium on Logistcs. Centre for Concurrent Enterprise, Nottingham University Business School, pp. 498-506.

Chen, C.P., Zhang, C.-Y., 2014. Data-intensive applications, challenges, techniques and technologies: A survey on Big Data. Information Sciences 275, 314-347.

Dhall, R., 2013. Advances in edible coatings for fresh fruits and vegetables: a review. Critical reviews in food science and nutrition 53, 435-450.

DutchNews.nl, 2018. The Netherlands is the second-largest agricultural exporter after US.

https://www.dutchnews. nl/news/2018/01/the-netherlands-is-the-second-largest-agricultural-exporter-afterus/.

Farkas, J., Ehlermann, D., Mohácsi-Farkas, C., 2014. Food technologies: food irradiation.

Fedak, V., 2018. Blockchain and Big Data: the match made in heavens. Towards Data Science https://towardsdatascience.com/blockchain-and-big-data-the-match-made-in-heavens-337887a0ce73. Floribusiness, R., 2017. 2017 flower exports from the Netherlands will reach new record of $€ 6$ billion. Floribusiness https://www.hortipoint.nl/floribusiness/2017-flower-exports-from-the-netherlands-will-reachnew-record-e6-billion/.

Ge, L., Brewster, C., Spek, J., Smeenk, A., Top, J., van Diepen, F., Klaase, B., Graumans, C., de Wildt, M.d.R., 2017. Blockchain for agriculture and food. Wageningen Economic Research.

Gilmore, D., 2010. What is a Smarter Supply Chain? SupplyChainDigest

http://www.scdigest.com/ASSETS/FirstThoughts/10-08-26-1. php?cid=3701.

Gol, N.B., Patel, P.R., Rao, T.R., 2013. Improvement of quality and shelf-life of strawberries with edible coatings enriched with chitosan. Postharvest Biology and Technology 85, 185-195.

Harkema, H., Paillart, M., Lukasse, L., Westra, E., Hogeveen, E., 2017. Transport and storage of cut roses: endless possibilities?: guide of practice for sea freight of cut roses developed within GreenCHAINge project. Wageningen Food \& Biobased Research.

Heising, J.K., 2014. Intelligent packaging for monitoring food quality: a case study on fresh fish. Wageningen University.

Holt, J., Leach, A., Johnson, S., Tu, D., Nhu, D., Anh, N., Quinlan, M., Whittle, P., Mengersen, K., Mumford, J., 2018. Bayesian networks to compare pest control interventions on commodities along agricultural production chains. Risk Analysis 38, 297-310.

Lukasse, L., Mensink, M., Wissink, E., 2017. A floor cover to improve temperature distribution and quality preservation in maritime refrigerated container transport of grapes. Wageningen Food \& Biobased Research. Lukasse, L., Staal, M., 2016. Optimizing air flow distribution in maritime refrigerated containers, VIII International Postharvest Symposium: Enhancing Supply Chain and Consumer Benefits-Ethical and Technological Issues 1194, pp. 1391-1398.

Lukasse, L.J.S., Harkema, H., Otma, E.C., Paillart, M.J.M., 2013. Quest II produce quality research overview. Wageningen UR - Food \& Biobased Research, Wageningen.

Luning, P.A., Marcelis, W.J., 2006. A techno-managerial approach in food quality management research.

Trends in Food Science \& Technology 17, 378-385.

Magnin, C., 2016. How big data will revolutionize the global food chain. Digital McKinsey

https://www.mckinsey.com/business-functions/digital-mckinsey/our-insights/how-big-data-will-

revolutionize-the-global-food-chain.

Mahajan, P.V., Caleb, O.J., Singh, Z., Watkins, C.B., Geyer, M., 2014. Postharvest treatments of fresh

produce. Phil. Trans. R. Soc. A 372, 20130309. 
Matindoust, S., Baghaei-Nejad, M., Zou, Z., Zheng, L.-R., 2016. Food quality and safety monitoring using gas sensor array in intelligent packaging. Sensor Review 36, 169-183.

Salin, V., 1998. Information technology in agri-food supply chains. The International Food and Agribusiness Management Review 1, 329-334.

Schirra, M., D'hallewin, G., Ben-Yehoshua, S., Fallik, E., 2000. Host-pathogen interactions modulated by heat treatment. Postharvest Biology and Technology 21, 71-85.

Schouten, R., Van Kooten, O., van der Vorst, J., Marcelis, W., Luning, P., 2010. Quality controlled logistics in vegetable supply chain networks: how can an individual batch reach an individual consumer in the optimal state?, XXVIII International Horticultural Congress on Science and Horticulture for People (IHC2010): International Symposium on 936, pp. 45-52.

Schripsema, A., Oostewechel, R., 2018. HAED-Jo: postharvest systems

Fact-finding mission. Wageningen Publication http://dx.doi.org/10.18174/453843/1832.

Tromp, S.-O., Haijema, R., Rijgersberg, H., van der Vorst, J.G.A.J., 2016. A systematic approach to preventing chilled-food waste at the retail outlet. International Journal of Production Economics 182, 508518.

Tromp, S.-O., Harkema, H., Hogeveen, E., Rijgersberg, H., Woltering, E.J., 2017. On the validation of improved quality-decay models of potted plants. Postharvest Biology and Technology 123, 119-127. Tromp, S.-O., Harkema, H., Rijgersberg, H., Westra, E., Woltering, E.J., 2015. Modelling the quality of potted plants after dark storage. Postharvest Biology and Technology 103, 9-16.

Tromp, S.-O., Rijgersberg, H., Pereira da Silva, F., Bartels, P., 2012a. Retail benefits of dynamic expiry dates-Simulating opportunity losses due to product loss, discount policy and out of stock. International Journal of Production Economics 139, 14-21.

Tromp, S.-O., van der Sman, R.G.M., Vollebregt, H.M., Woltering, E.J., 2012b. On the prediction of the remaining vase life of cut roses. Postharvest Biology and Technology 70, 42-50.

Tromp, S.O., Rijgersberg, H., Franz, E., 2012c. Reusing salad from salad bars-simulating the effects on product loss, microbial safety and product quality. International journal of food science \& technology 47 , 1144-1150.

Van der Vorst, J., Beulens, A., van Beek, P., 2005. 10. Innovations in logistics and ICT in food supply chain networks. Innovation in, 245.

Van der Vorst, J.G., Beulens, A.J., 2002. Identifying sources of uncertainty to generate supply chain redesign strategies. International Journal of Physical Distribution \& Logistics Management 32, 409-430.

van der Vorst, J.G., Schouten, R.E., Luning, P.A., van Kooten, O., 2014. Designing new supply chain networks: tomato and mango case studies, Horticulture: Plants for People and Places, Volume 1. Springer, pp. 485-501.

Van Der Vorst, J.G., Tromp, S.-O., Zee, D.-J.v.d., 2009. Simulation modelling for food supply chain redesign; integrated decision making on product quality, sustainability and logistics. International Journal of Production Research 47, 6611-6631.

van der Vorst, J.G., van Kooten, O., Luning, P.A., 2011. Towards a diagnostic instrument to identify improvement opportunities for quality controlled logistics in agrifood supply chain networks. International journal on food system dynamics 2, 94-105.

Viviano, F., 2017. This Tiny Country Feeds the World. National Geographic https://www.nationalgeographic.com/magazine/2017/09/holland-agriculture-sustainable-farming/.

Weitjens, M., 2016. Top 10 Largest Players in Flower Exports.

https://www.flowercompanies.com/blog/netherlands-leader-on-the-flower-export-market.

Wu, W., Cronjé, P., Nicolai, B., Verboven, P., Opara, U.L., Defraeye, T., 2018. Virtual cold chain method to model the postharvest temperature history and quality evolution of fresh fruit-A case study for citrus fruit packed in a single carton. Computers and Electronics in Agriculture 144, 199-208. 


\section{Appendix}

A. The conceptual framework for estimating post-harvest food losses (Aulakh et al., 2013)

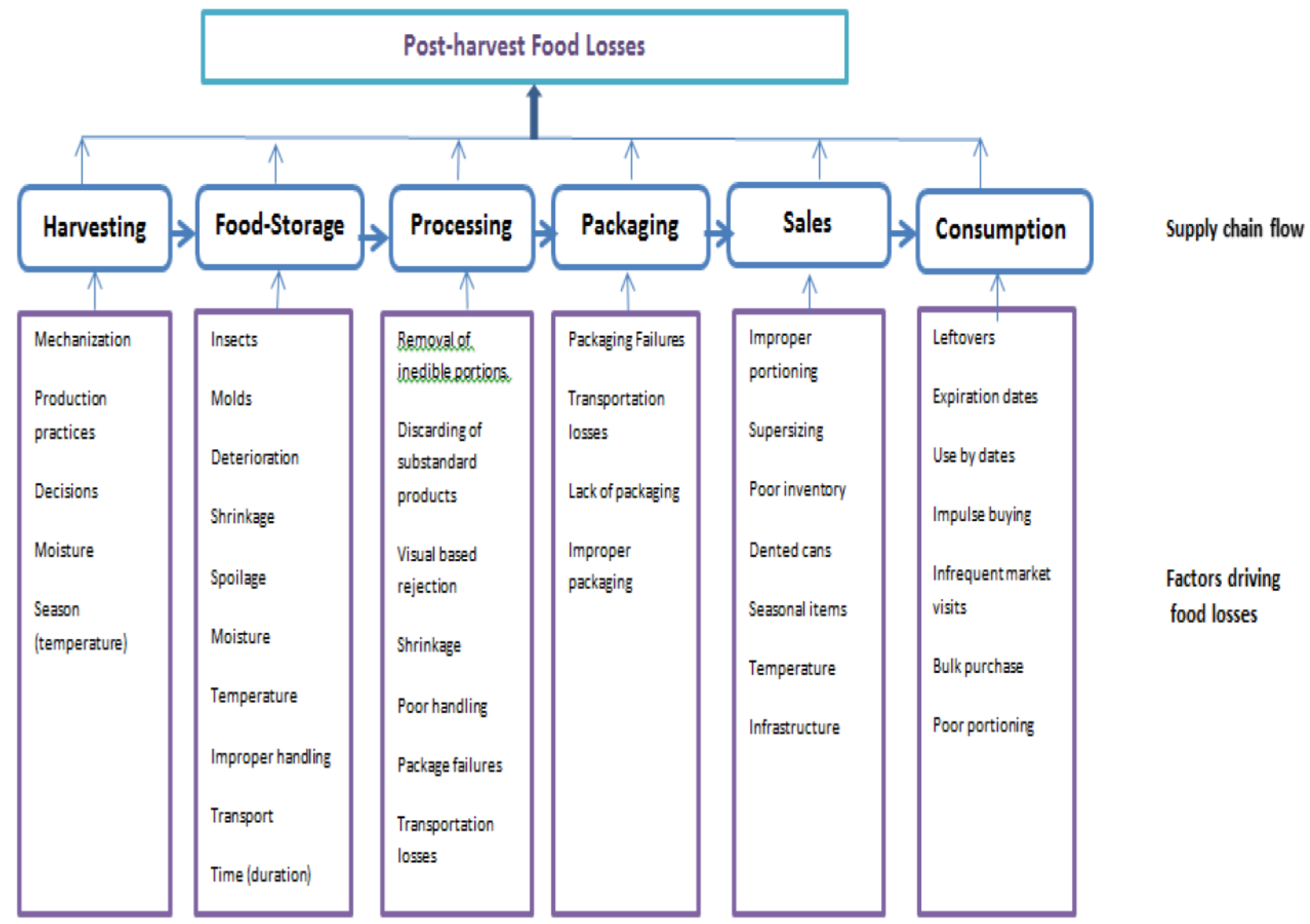




\section{B. Overview of postharvest treatments of fresh produce (Source: Mahajan et al. (2014))}

\begin{tabular}{|c|c|c|c|}
\hline treatment & benefits & limitations & commercial example application \\
\hline heat treatment & $\begin{array}{l}\text { reduction of chilling injury, delay of ripening, } \\
\text { killing of critical insect contaminants and } \\
\text { controls decay }\end{array}$ & high-energy costs and added labour & $\begin{array}{l}\text { potato, tomato, carrot, strawberry, asparagus, } \\
\text { broccoli, beans, kiwi, celery, lettuce, melon, } \\
\text { grape, plum, peach, spinach and rocket } \\
\text { leaves [5-11] }\end{array}$ \\
\hline edible coating & $\begin{array}{l}\text { provides a partial barrier, minimizes moisture } \\
\text { loss; establishes modified atmosphere; } \\
\text { preserves colour and texture; retains } \\
\text { natural aroma }\end{array}$ & $\begin{array}{l}\text { cost of scaling up, lack of edible materials with } \\
\text { desired properties, regulatory challenges }\end{array}$ & $\begin{array}{l}\text { apples, pears, carrots, celery, strawberry and } \\
\text { mushrooms [12-15] }\end{array}$ \\
\hline irradiation & $\begin{array}{l}\text { inhibits sprouting of tubers, bulbs and roots, } \\
\text { meets quarantine requirements for export } \\
\text { trade and recognized as a safe process }\end{array}$ & $\begin{array}{l}\text { capital intensive, lack of harmonization of } \\
\text { regulations, slow consumer acceptance } \\
\text { owing to perceived association with } \\
\text { radioactivity }\end{array}$ & potato, onion, strawberry and mango [16-19] \\
\hline $\begin{array}{l}\text { antimicrobial and } \\
\text { anti-browning agents }\end{array}$ & $\begin{array}{l}\text { retards browning, deterioration of texture and } \\
\text { microbial growth }\end{array}$ & $\begin{array}{l}\text { inaccessible sites for treatments within fresh } \\
\text { produce such as calyx and wax area }\end{array}$ & $\begin{array}{l}\text { apple, strawberry, lettuce, melon, orange, } \\
\text { prune, tomato, grapes and fresh-cut } \\
\text { produce [20-29] }\end{array}$ \\
\hline NO & $\begin{array}{l}\text { inhibits ethylene biosynthesis, reduces } \\
\text { respiration rate, water loss, browning, and } \\
\text { lower incidence of postharvest diseases }\end{array}$ & $\begin{array}{l}\text { commercial application depends upon the } \\
\text { development of a smart carrier/controlled } \\
\text { release system for NO }\end{array}$ & $\begin{array}{l}\text { apple, banana, kiwifruit, mango, peach, pear, } \\
\text { plum, strawberry, tomato, papaya, loquat, } \\
\text { jujube fruit and bayberry [30-35] }\end{array}$ \\
\hline sulfur dioxide & prevents postharvest decay & $\begin{array}{l}\text { higher concentration may induce injuries and } \\
\text { sulfite residues pose a health risk }\end{array}$ & $\begin{array}{l}\text { grapes, litchi, fig, banana, lemon, apple and } \\
\text { blueberries [36-39] }\end{array}$ \\
\hline ozone & $\begin{array}{l}\text { easily incorporated into existing cold storage, } \\
\text { washing system, better efficacy than } \\
\text { chlorine }\end{array}$ & $\begin{array}{l}\text { does not penetrate natural openings, further } \\
\text { research is needed to improve application }\end{array}$ & $\begin{array}{l}\text { apples, cherries, carrots, garlic, kiwi, onions, } \\
\text { peaches, plums, potatoes and table grapes } \\
\text { [40-44] }\end{array}$ \\
\hline ethylene & $\begin{array}{l}\text { triggers ripening process thereby improves } \\
\text { fruit colour and quality }\end{array}$ & $\begin{array}{l}\text { need of optimum ethylene concentration, } \\
\text { storage conditions for faster and more } \\
\text { uniform ripening }\end{array}$ & $\begin{array}{l}\text { banana, avocado, persimmon, tomato, } \\
\text { kiwifruit, mango and citrus fruits [ } 45-58 \text { ] }\end{array}$ \\
\hline $1-M C P$ & $\begin{array}{l}\text { maintains fruit cell wall integrity and peel } \\
\text { colour, and develop aroma and flawour }\end{array}$ & $\begin{array}{l}\text { it can increase susceptibility to } \mathrm{CO}_{2} \text { injury and } \\
\text { chilling disorders. Additional exposure time } \\
\text { is required for fruit to recover its ability to } \\
\text { ripen normally }\end{array}$ & $\begin{array}{l}\text { apple, avocado, banana, broccoli, cucumber, } \\
\text { date, kiwifruit, mango, melon, nectarine, } \\
\text { papaya, peach, pear, pepper, persimmon, } \\
\text { pineapple, plantain, plum, squash and } \\
\text { tomato [ } 59-72]\end{array}$ \\
\hline CA storage & $\begin{array}{l}\text { retards senescence, associated biochemical and } \\
\text { physiological changes, reduction in decay } \\
\text { severity }\end{array}$ & $\begin{array}{l}\text { capital intensive, fruit volumes must be high } \\
\text { and extended storage periods are needed to } \\
\text { make investment economical }\end{array}$ & $\begin{array}{l}\text { apple, pear, avocado, strawberry, cherry, } \\
\text { cabbages, kiwifruit, avocados, persimmon, } \\
\text { pomegranate, asparagus, banana, broccoli, } \\
\text { canberry, mango, melon, nectarine, } \\
\text { peaches and plums [B-83] }\end{array}$ \\
\hline MAP & $\begin{array}{l}\text { delay in respiration, senescence, and slows } \\
\text { down rate of deterioration }\end{array}$ & $\begin{array}{l}\text { condensation inside the package resulting in } \\
\text { microbial growth and decay of produce }\end{array}$ & $\begin{array}{l}\text { strawberry, banana, cherries, carrots, fresh-cut } \\
\text { fruits, salad mix and leafy green vegetables } \\
\text { [84-89] }\end{array}$ \\
\hline
\end{tabular}




\section{The training modules designed by the NARA project (Source: The project Website of NARA)}

\section{MODULES OF TRAINING CONTENTS}

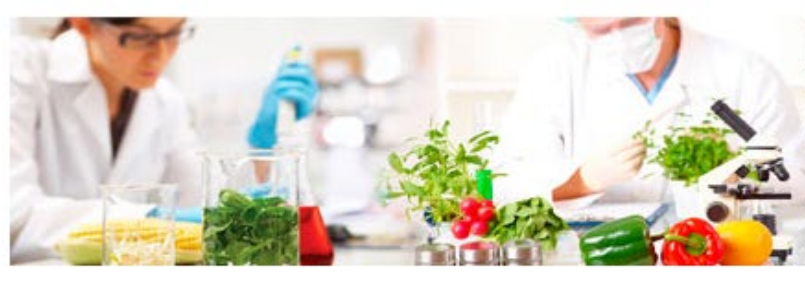

MODULE 1: Food Safety learning contents

Learning Subunit 1.1. Principles and importance of Food Safety in food supply chain, especially in farms

Learning Subunit 1.2. Good Safety Practices and Food Safety Regulations

Module >

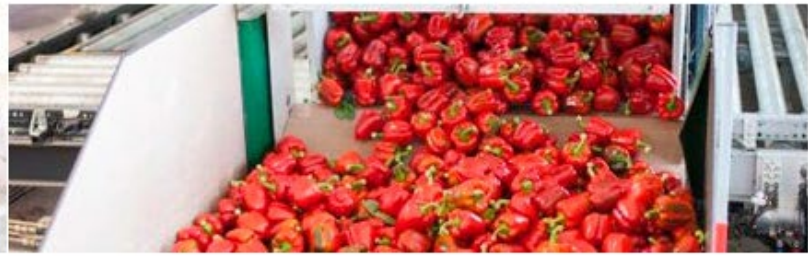

MODULE 2: Postharvest Technologies

Learning Subunit 2.1. Cultural and harvesting crops care and its influence in the quality produce obtained

Learning Subunit 2.2. Postharvest technologies to increase farming products shelf-life

Learning Subunit 2.3. Development of new fruit and vegetable produces

Module >

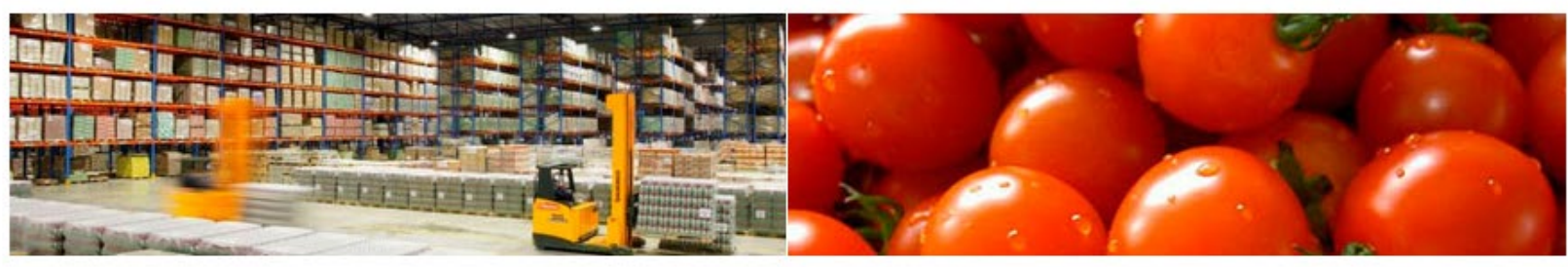

MODULE 3: Transport \& Logistics [-

Learning Subunit 3.1. Warehousing of fresh products

Learning Subunit 3.2. Transportation techniques and regulations

Module >

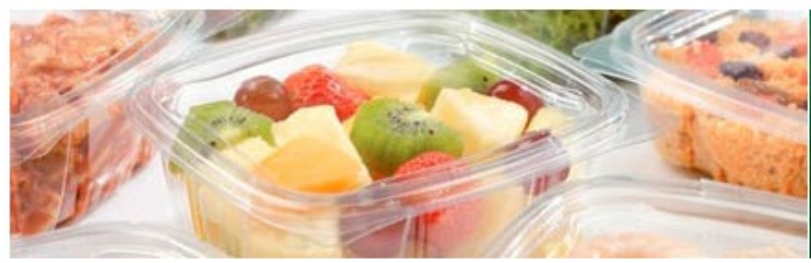

MODULE 5: Packaging learning contents [f

Learning Subunit 5.1. Packaging possibilities

Learning Subunit 5.2. Environmental friendly options

Module >
MODULE 4: Soil, water and byproducts

Learning Subunit 4.1. Agricultural soil formation, main soil properties, soil fertilization and soil tillage

Learning Subunit 4.2. Irrigation in agriculture, irrigation systems and fertigation

Learning Subunit 4.3. Byproducts

Module >

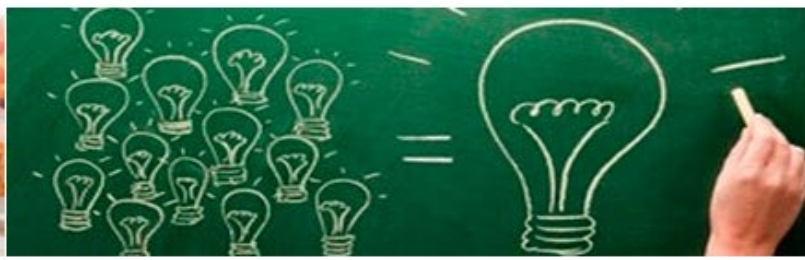

MODULE 6: Entrepreneurship [-

Learning Subunit 6.1. Creation, Organization and Management of a small profitable business

Learning Subunit 6.2. Implementation of administrative and financial issues related to farming business

Module > 
D. The "Smart map" to the Supply Chain of the Future (Source: IBM)

SCM COMPEIENCY AREAS

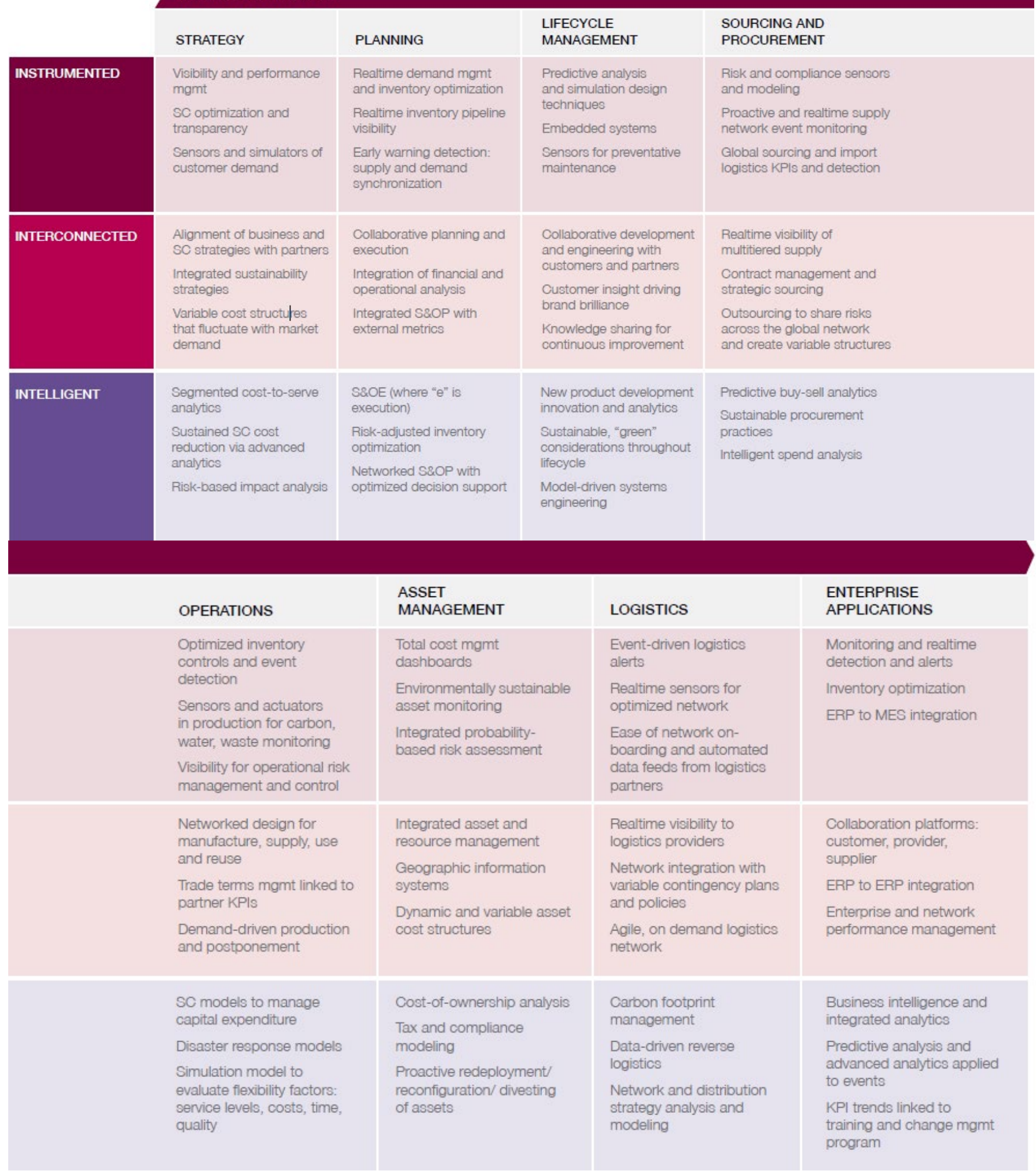




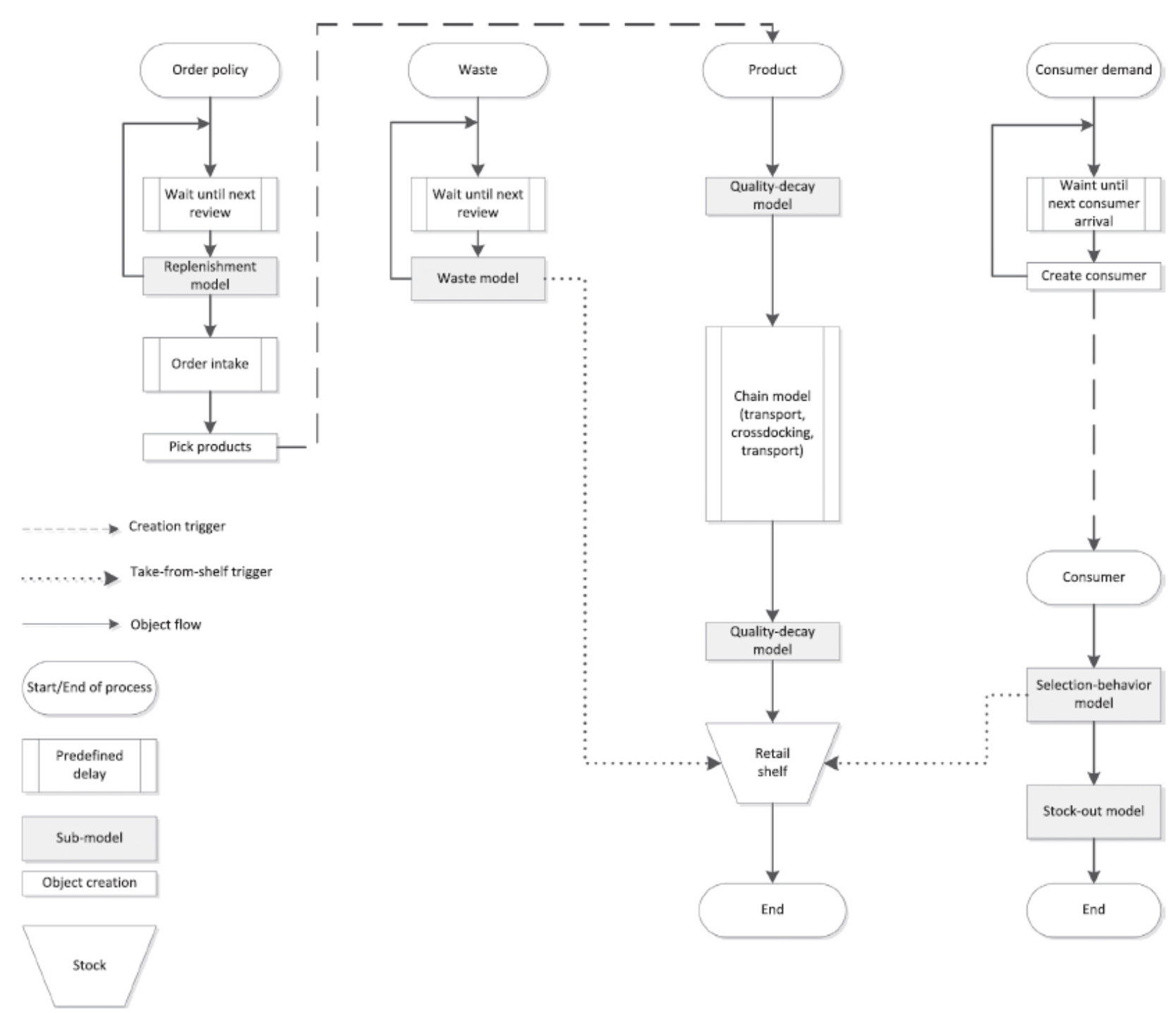

E. The schematic simulation overview containing the quality-decay model (Tromp et al., 2016) 


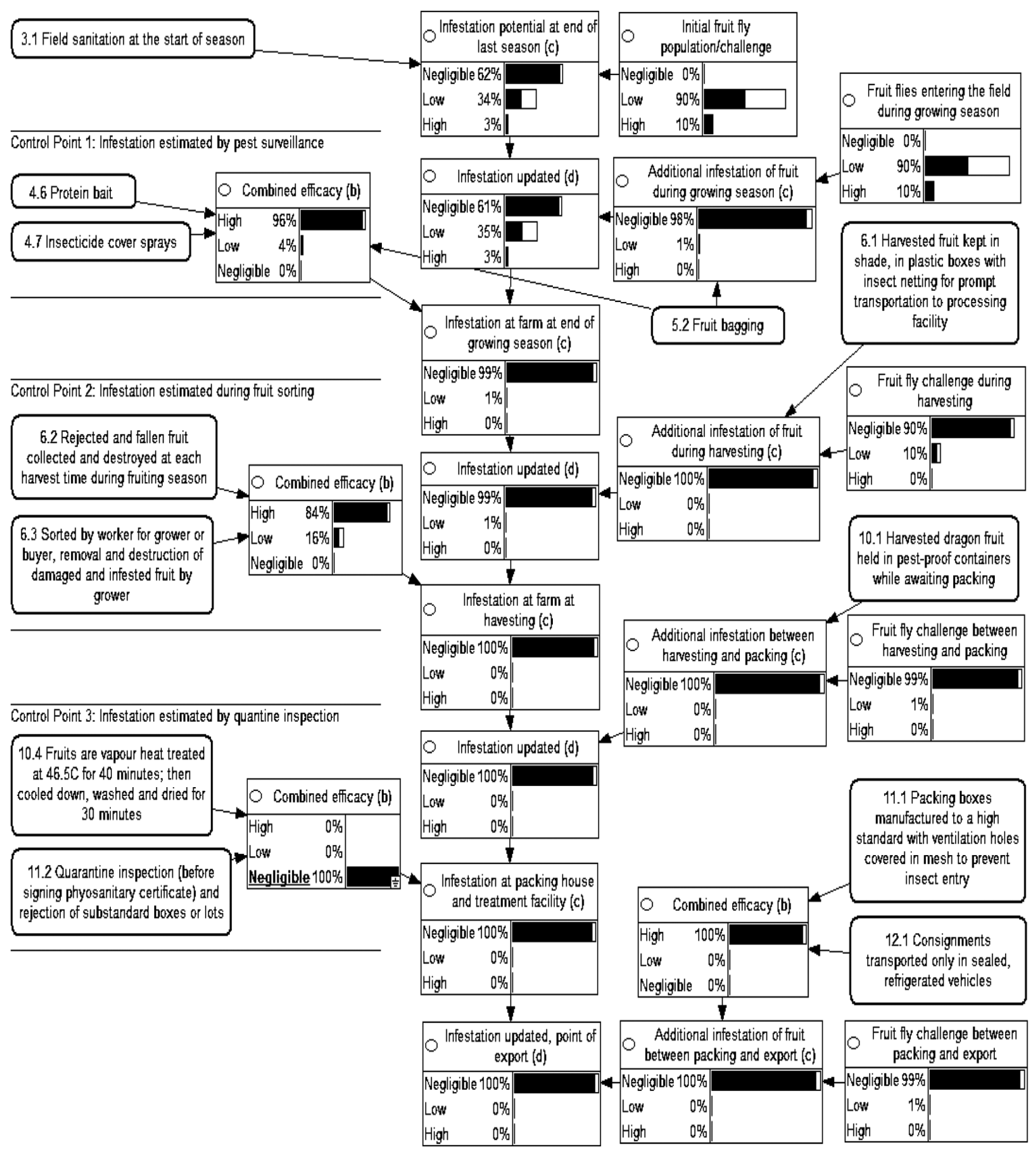

\section{F. Bayesian network of pest infestation on a production chain: model structure developed for fruit fly on dragon fruit in Vietnam (Holt et al., 2018)}




\section{G. Opportunities, Challenges and learning objectives for different stakeholders Ge et al. (2017)}

\begin{tabular}{|c|c|c|c|}
\hline Stakeholders & Opportunities & Challenges & Learning objectives \\
\hline Food producers & $\begin{array}{l}\text { - Added value to food } \\
\text { products with credence } \\
\text { attributes due to increased } \\
\text { transparency and assurance } \\
\text { of provenance information } \\
\text { - Fairer price and lower costs } \\
\text { due to the removal of } \\
\text { intermediaries } \\
\text { - Better access to global } \\
\text { market } \\
\text { - Access to alternative } \\
\text { financing arrangements } \\
\text { - Direct contact with } \\
\text { consumers }\end{array}$ & $\begin{array}{l}\text { - Organising BCT } \\
\text { implementation } \\
\text { - Access to established } \\
\text { blockchain } \\
\text { - Getting the right } \\
\text { conditions into smart } \\
\text { contracts }\end{array}$ & $\begin{array}{l}\text { - General knowledge of BCT } \\
\text { - How to benefit from BCT }\end{array}$ \\
\hline Certification bodies & $\begin{array}{l}\text { - Increased value of } \\
\text { certificates due to the } \\
\text { improved transparency and } \\
\text { reliability of certificates } \\
\text { - Lower transaction costs due } \\
\text { to efficient process } \\
\text { - Risk based auditing }\end{array}$ & $\begin{array}{l}\text { - New competencies } \\
\text { needed } \\
\text { - Potential threat to } \\
\text { current business model }\end{array}$ & $\begin{array}{l}\text { How BCT can enhance the } \\
\text { chain of custody and } \\
\text { efficiency of certification } \\
\text { processes }\end{array}$ \\
\hline $\begin{array}{l}\text { Governmental organisations } \\
\text { (RVO, NVWA) }\end{array}$ & $\begin{array}{l}\text { - Reliable data } \\
\text { - Efficient regulatory } \\
\text { processes } \\
\text { - Lower transaction costs }\end{array}$ & $\begin{array}{l}\text { - New competencies } \\
\text { needed } \\
\text { - Existing national and } \\
\text { international regulatory } \\
\text { framework }\end{array}$ & $\begin{array}{l}\text { - Understanding the social } \\
\text { implications of BCT } \\
\text { - Identifying key use cases }\end{array}$ \\
\hline Retail/Trader & $\begin{array}{l}\text { - Improving transparency and } \\
\text { traceability } \\
\text { - Access to more information } \\
\text { on the provenance of food } \\
\text { products } \\
\text { - Providing reliable } \\
\text { information to consumers } \\
\text { - Improving brand image }\end{array}$ & $\begin{array}{l}\text { - Compatibility with } \\
\text { existing systems } \\
\text { - Compliance of other } \\
\text { players in the supply } \\
\text { chain } \\
\text { - Privacy concerns } \\
\text { - Traceability and } \\
\text { provenance of compound } \\
\text { products } \\
\text { - Scalability of BCT }\end{array}$ & $\begin{array}{l}\text { - Understanding the } \\
\text { potential of BCT } \\
\text { - Identifying and prioritise } \\
\text { key use cases }\end{array}$ \\
\hline $\begin{array}{l}\text { Producers of digital } \\
\text { equipment (e.g. sensors) }\end{array}$ & $\begin{array}{l}\text { - Increasing market for } \\
\text { hardware products } \\
\text { - Increasing potential to } \\
\text { capitalise on data captured }\end{array}$ & $\begin{array}{l}\text { - Interoperability } \\
\text { - New competence needed }\end{array}$ & $\begin{array}{l}\text { - How to design blockchain- } \\
\text { ready products }\end{array}$ \\
\hline $\begin{array}{l}\text { Standard organisations on } \\
\text { sustainability (e.g., Organic) }\end{array}$ & $\begin{array}{l}\text { Potential to reduce } \\
\text { transaction costs due to } \\
\text { removal of intermediary } \\
\text { processes }\end{array}$ & $\begin{array}{l}\text { - Harmonisation of } \\
\text { standards } \\
\text { - Choice of indicators }\end{array}$ & $\begin{array}{l}\text { - How to use BCT to improve } \\
\text { compliance to standards }\end{array}$ \\
\hline $\begin{array}{l}\text { Standard organisations on } \\
\text { information standards (e.g., } \\
\text { GS1) }\end{array}$ & $\begin{array}{l}\text { - Enhancing the } \\
\text { implementation of standards } \\
\text { through BCT }\end{array}$ & $\begin{array}{l}\text { - Compatibility with } \\
\text { existing standards }\end{array}$ & $\begin{array}{l}\text { How to take into account } \\
\text { the implications of } \\
\text { blockchain in norm setting }\end{array}$ \\
\hline Knowledge institutions & $\begin{array}{l}\text { Deriving more value of } \\
\text { existing data and } \\
\text { information systems in } \\
\text { agrifood domain } \\
\text { - New research opportunities }\end{array}$ & $\begin{array}{l}\text { - Identifying the right } \\
\text { problems and partners } \\
\text { - Establishing research } \\
\text { consortium for trial and } \\
\text { exploration }\end{array}$ & $\begin{array}{l}\text { How BCT can be used to } \\
\text { enhance knowledge } \\
\text { generation and } \\
\text { dissemination }\end{array}$ \\
\hline Agro-ICT companies & $\begin{array}{l}\text { - Increasing market potential } \\
\text { for providing software } \\
\text { solutions }\end{array}$ & $\begin{array}{l}\text { - Identifying the right use } \\
\text { cases and users }\end{array}$ & $\begin{array}{l}\text { - How to apply BCT to create } \\
\text { new value proposition }\end{array}$ \\
\hline Blockchain start-ups & $\begin{array}{l}\text { - Initiating new business } \\
\text { opportunities } \\
\text { - Supporting social innovation } \\
\text { with distributed governance } \\
\text { models }\end{array}$ & $\begin{array}{l}\text { - Finding the right funder } \\
\text { and partners }\end{array}$ & $\begin{array}{l}\text { How to build minimum } \\
\text { viable ecosystem for BCT } \\
\text { implementation }\end{array}$ \\
\hline
\end{tabular}


Assess the need of traceability by customers and regulators

Identify the parameters significantly affecting product safety and quality and cold chain performance

Estimate the rate of product devaluation due to non-conformance of parameters identified
Estimate the impact of lack of traceability

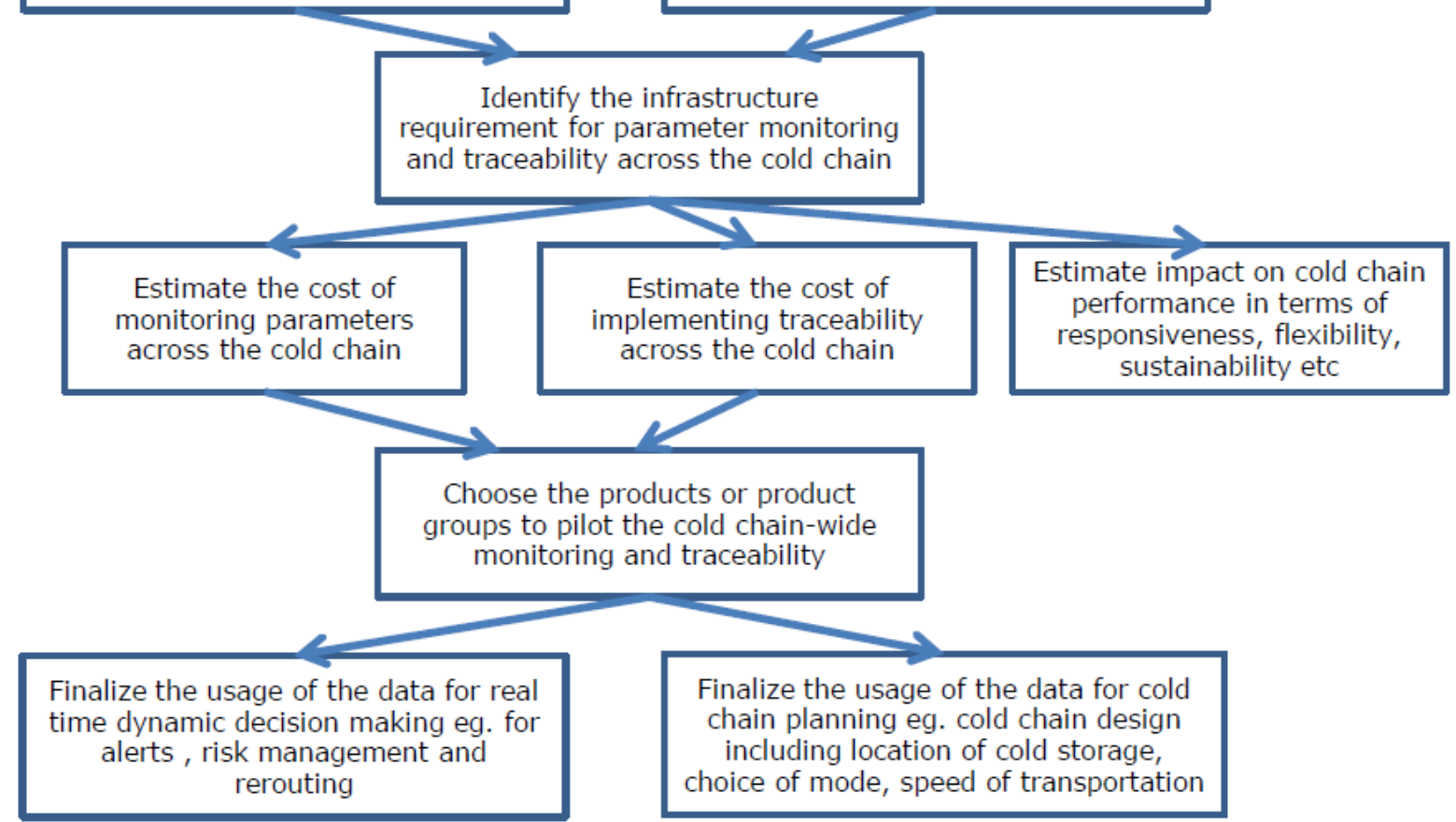

\section{H. Framework for 'big data' development and implementation in cold chain logistics} (Chaudhuri et al., 2016) 
I. Generic logistics decisions versus specific QCL decisions (Source: van der Vorst et al. (2011))

\begin{tabular}{|c|c|}
\hline Generic logistics decisions & Specific QCL decisions \\
\hline $\begin{array}{l}\text { Determine generic customer service } \\
\text { standards } \\
\text { - Customer needs (quantity, quality, etc.) } \\
\text { - Customer service levels (lead time, } \\
\text { reliability, etc.) } \\
\text { - Determine requirements on supply of } \\
\text { products in each stage of the chain. }\end{array}$ & $\begin{array}{l}\text { Determine customer acceptance levels and } \\
\text { periods for specific market segments using } \\
\text { accepted and measurable quality standards. } \\
\text { Translate this into specific product quality } \\
\text { requirements for each stage in the supply chain } \\
\text { (next to of course volume and timing } \\
\text { requirements). }\end{array}$ \\
\hline $\begin{array}{l}\text { Determine facility network design } \\
\text { - Number, location of stocking points } \\
\text { - Equipment selection, capacity planning }\end{array}$ & $\begin{array}{l}\text { Use customer requirements data, information on } \\
\text { supply qualities and volumes and transport } \\
\text { scenarios with quality predictions to determine } \\
\text { the required network design and equipment. }\end{array}$ \\
\hline $\begin{array}{l}\text { Determine inventory management } \\
\text { - Position Customer Order Decoupling } \\
\text { Point (CODP); push-pull strategies } \\
\text { - Warehousing policies }\end{array}$ & $\begin{array}{l}\text { Use supply chain data to determine the optimal } \\
\text { position of inventory points in the network taking } \\
\text { predicted quality changes (and thus } \\
\text { environmental conditions) into account. }\end{array}$ \\
\hline $\begin{array}{l}\text { Determine information flows and order } \\
\text { processing } \\
\text { - Ordering rules } \\
\text { - Order inventory interface procedure } \\
\text { - Order picking procedures }\end{array}$ & $\begin{array}{l}\text { Determine Critical Quality Points (CQPs) to } \\
\text { monitor quality changes. Use quality prediction } \\
\text { models and product quality information to apply } \\
\text { optimal picking policies (e.g. first-expired-first- } \\
\text { out policy). Re-sort batches if needed. Aim for } \\
\text { homogenous batches for specific market } \\
\text { segments. }\end{array}$ \\
\hline $\begin{array}{l}\text { Plan order fulfilment } \\
\text { - Allocate harvested produce to customer } \\
\text { orders and deliver the products without } \\
\text { dealing with quality changes and } \\
\text { differences that occur in the supply } \\
\text { process. A batch is not re-sorted or re- } \\
\text { allocated unless serious issues arise. } \\
\text { - Determine transport management (mode, } \\
\text { scheduling) }\end{array}$ & $\begin{array}{l}\text { Dynamic logistics planning in the complete chain } \\
\text { based upon real time product-quality information } \\
\text { (using critical quality points and predictive } \\
\text { models). If needed, batches are re-sorted into } \\
\text { homogeneous batches, re-allocated to different } \\
\text { market segments, transported with different } \\
\text { modes or environmental conditions are adapted } \\
\text { to meet customer requirements. Technologies } \\
\text { such as data loggers, RFID and GPS are used to } \\
\text { capture all relevant information, translated into } \\
\text { meaningful information through models. }\end{array}$ \\
\hline
\end{tabular}






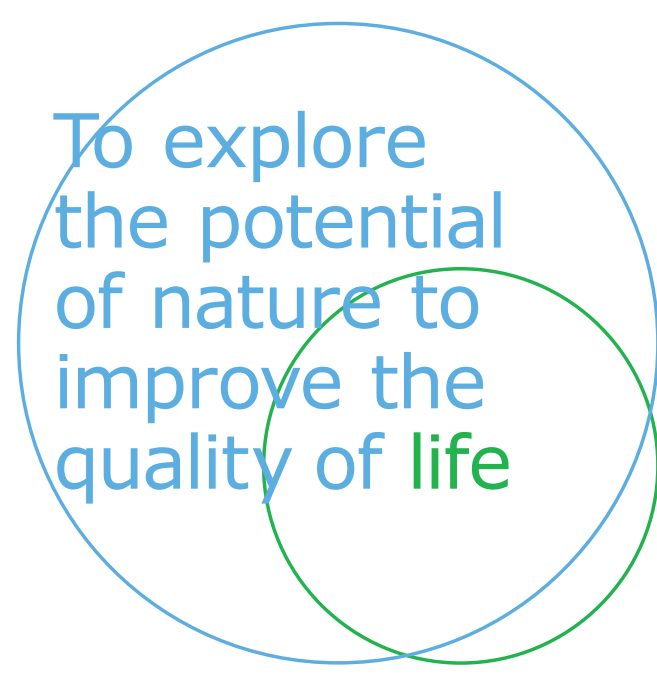

Wageningen Food \& Biobased Research Bornse Weilanden 9

6708 WG Wageningen

The Netherlands

www.wur.eu/wfbr

Einfo.wfbr@wur.nl

Report 1862

ISBN 978-94-6343-362-4

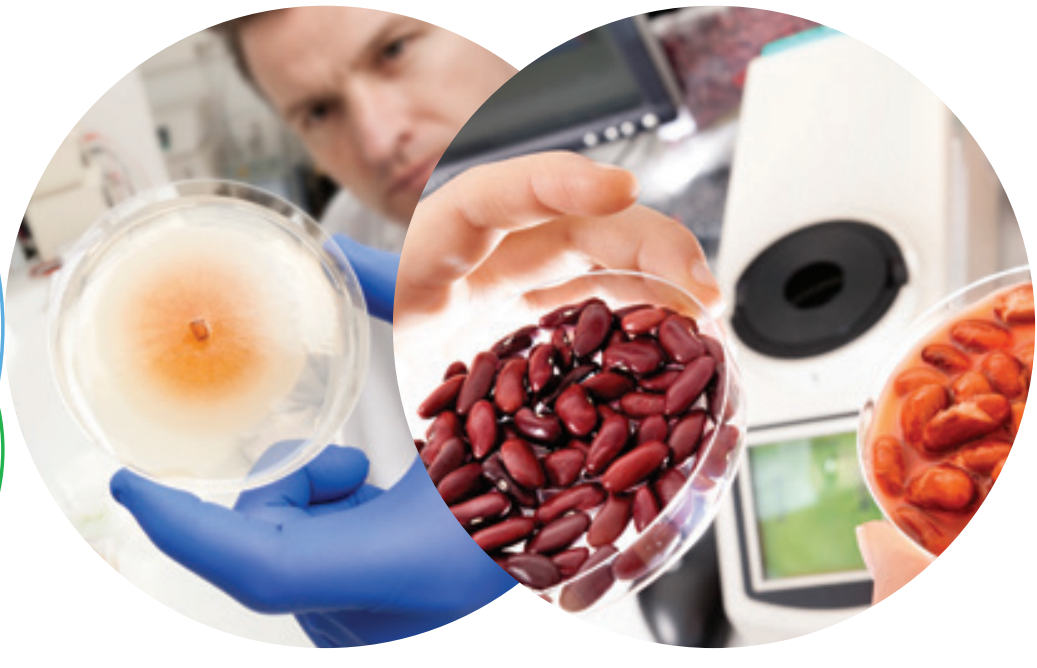

The mission of Wageningen University and Research is "To explore the potential of nature to improve the quality of life". Under the banner Wageningen University \& Research, Wageningen University and the specialised research institutes of the Wageningen Research Foundation have joined forces in contributing to finding solutions to important questions in the domain of healthy food and living environment. With its roughly 30 branches, 5,000 employees and 10,000 students, Wageningen University \& Research is one of the leading organisations in its domain. The unique Wageningen approach lies in its integrated approach to issues and the collaboration between different disciplines. 